\title{
IDENTIFICAÇÃO E LOCALIZAÇÃO DE UM GENE DE RESISTÊNCIA DE MILHO A Exserohilum turcicum (Pass.) \\ Leonard \& Suggs ATRAVÉS DO USO DE MARCADORES MICROSSATÉLITES
}

\section{JULIANA BERNARDI OGLIARI}

Engenheira Agrônoma

\section{Orientador: Prof. Dr. LUIS EDUARDO ARANHA CAMARGO} Co-orientador: Prof. Dr. ISAÍAS OLIVIO GERALDI

\begin{abstract}
Tese apresentada à Escola Superior de Agricultura "Luiz de Queiroz", Universidade de São Paulo, para obtenção do titulo de Doutor em Agronomia, Área de Concentração: Genética e Melhoramento de Plantas.
\end{abstract}

PIRACICABA

Estado de São Paulo - Brasil

Abril - 1999 


\section{Dados Internacionais de Catalogação na Publicação (CIP) DIVISÃo DE BIBLIOTECA E DOCUMENTAÇÃO - Campus "Luiz de Queiroz"/USP}

Ogliari, Juliana Bernardi

Identificaçăo e localizaçăo de um gene de resistência de milho a Exserohilum turcicum (Pass.) Leonard \& Suggs. através do uso de marcadores microssatélites / Juliana Bernardi Ogliari. - - Piracicaba, 1999.

115 p. : il.

Tese (doutorado) - - Escola Superior de Agricultura Luiz de Queiroz, 1999. Bibliografia.

1. Fungo fitopatôgenico 2. Gene 3. Helmintosporiose-do-milho 4.

Mapeamento genético 5. Marcador molecular 6. Milho 7. Resistência à doença $\mathrm{I}$. Título

CDD 633.15

Permitida a copla total ou parcial deste documento, desde que citada 0 fonte 0 A utor: 
Aos meus filhos Marcelo, André e Rafaela e ao meu esposo Paulo, dedico

Aos meus pais Enzo e Linda e aos meus irmãos Alfredo e Júlio, ofereço 


\section{AGRADECIMENTOS}

Ao Prof. Dr. Luis Eduardo Aranha Camargo pela dedicada orientação e por ter proporcionado as melhores condições para a realização deste trabalho; Ao Prof. Dr. Isaías Olívio Geraldi pelo seu empenho em viabilizar meus anseios profissionais;

Aos professores do Departamento de Genética, Fitopatologia e Estatistica pelos ensinamentos;

Ao amigo e Prof. Dr. Carlos Alberto Labate por ter contribuído de maneira decisiva para a viabilização da etapa experimental;

Ao Prof. Dr. Roland Vencovsky pelas sugestões e, sobretudo, pelo seu exemplo de profissional dedicado;

Ao $\mathrm{Eng}^{\circ} \mathrm{Agr}^{\circ}$ Marco Antônio Magalhães pelo auxilio na condução das etapas experimentais (Sementes Agroceres S/A);

Ao Dr. M.L. Carson (North Carolina State University), Oswaldo Antônio P. Pereira (Sementes Agroceres S/A) e Hebert P. da Silva (Zeneca Sementes) por terem contribuído com o material genético utilizado nesse trabalho;

À Jaqueline Fogaça pela dedicação e auxilio nas atividades científicas e, sobretudo, pela amizade;

À Olga Suzuki (Sementes Agroflora) pelo auxillio na revisão do SUMMARY;

Aos funcionários do Departamento de Genética, especialmente, Claudio Roberto Segatelli, Fernandes de Araújo e Gustavo Alexandre Perina pelo pronto atendimento, quando solicitado;

Aos funcionários Marina, Jefferson, Pedro Arthuso, Edivaldo (Departamento de Fitopatologia), Candida Vanderléia (Departamento de Genética), Cristina, Eliane e Silvana (Biblioteca Central) por terem sido tão atenciosos; Aos colegas do laboratório de genética molecular e do curso de pós-graduação da ESALQ pelos momentos de convivio inesqueciveis; 
Às amigas Celia Correia Malvas, Regina Sartori Morello e Rosângela Moreira pelo incentivo, carinho e amizade e por terem contribuído para que essa etapa de minha vida fosse tão agradável;

À gloriosa ESALQ pelos ensinamentos e pelo agradável ambiente acadêmico;

A Piracicaba, uma vez mais, pela terna acolhida e pelos momentos memoráveis;

À FAPESP pelo apoio financeiro destinado ao desenvolvimento deste projeto;

À CAPES e UFSC pela oportunidade concedida para o aprimoramento da formação acadêmica. 


\section{SUMÁRIO}

Página

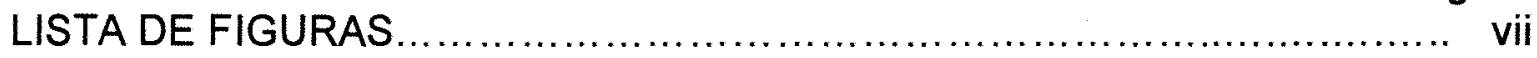

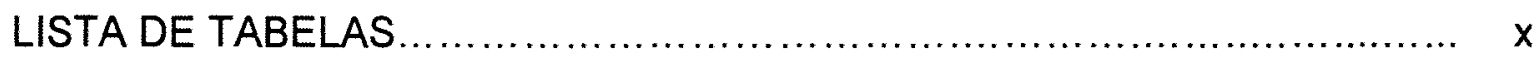

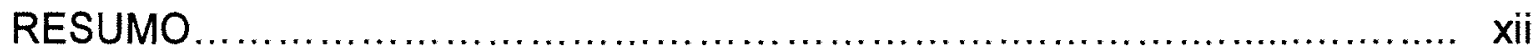

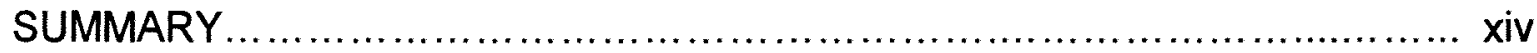

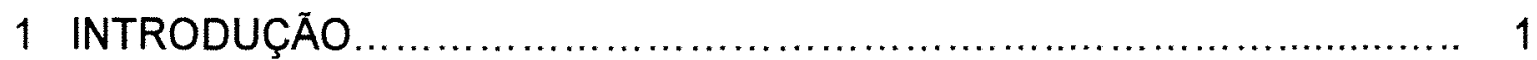

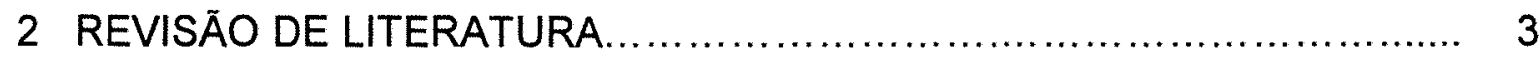

2.1PatossistemaZea mays/Exserohilum turcicum ............................... 3

2.1.1 Resistência monogênica........................................... 3

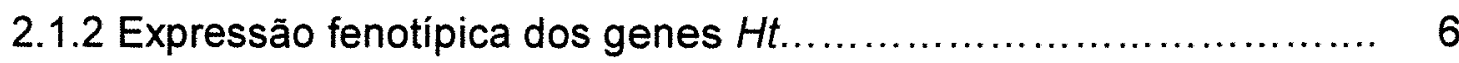

2.1.3 Variabilidade patogênica......................................... 9

2.2 Marcadores moleculares aplicados a seleção da resistência monogênica......................................................................... 11

2.3 Mapeamento de genes de resistência.................................... 14

2.3.1 Análise genética de linhagens quase isogênicas (LQ|s) ............. 15

2.3.2 Análise de segregantes agrupados (ASA) e de segregantes extremos da classe recessiva .................................... 19

2.4 Marcadores microssatélites............................................. 23

2.4.1 Características dos marcadores microssatélites..................... 23

2.4.2 Variabilidade dos locos microssatélites.............................. 26

2.4.3 Peculiaridades da amplificação dos locos SSRs..................... 29

2.4.4 Vantagens dos marcadores microssatélites........................ 30

3 MATERIAL E MÉTODOS .................................................... 33

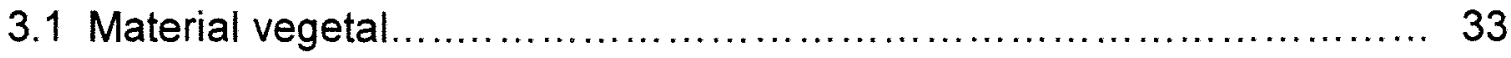

3.2 Extração de DNA vegetal........................................... 35

3.3 Otimização de protocolos de amplificação de locos microssatélites..... 36

3.4 Análise genética de linhagens quase isogênicas (LQ/s) ................ 40 
Página

3.5 Seleção de isolados que discriminam a reação de resistência

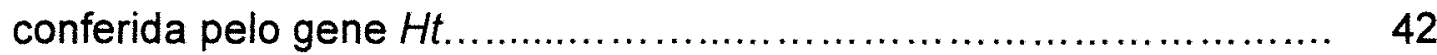

3.5.1 Cultura monospórica............................................. 42

3.5.2 Preparo de inóculo, inoculação e seleção de isolados.............. 42

3.6 Identificação de raças e do espectro de resistência conferido pelo

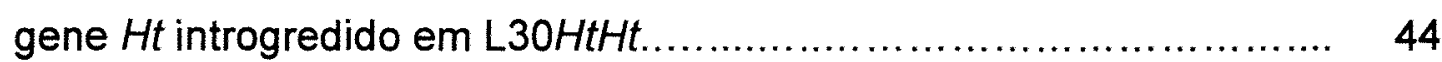

3.7 Fenotipagem de segregantes $R C_{1} F_{1}$ e análise dos segregantes

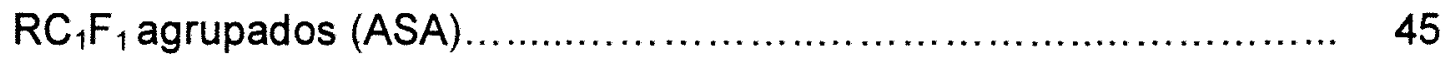

3.8 Localização do gene $H t$ pela análise dos indivíduos extremos da classe recessiva.

4 RESULTADOS E DISCUSSÃO.

4.1 Otimização de protocolos para amplificação de locos de microssatélites em milho

4.2 Análise genética de linhagens quase isogênicas (LQIs) de milho para um gene de resistência a Exserohilum turcicum...

4.3 Seleção de isolados e fenotipagem de segregantes $R C_{1} F_{1}$

4.4 Análise de indivíduos segregantes $R_{1} F_{1}$ agrupados (ASA).

4.5 Mapeamento de gene de resistência a $E$. turcicum pela análise dos individuos segregantes da classe recessiva.

4.6 Identificação de raças e do espectro de resistência conferido pelo gene $\mathrm{Ht}$.

5 CONCLUSÕES. 


\section{LISTA DE FIGURAS}

1 Produção e visualização de polimorfismos de comprimento gerados via PCR com "primers" que amplificam regiões de microssatélites de dois parentais hipotéticos $\left(P_{1}\right.$ e $\left.P_{2}\right)$ e do híbrido $F_{1}$ correspondente $\left(P_{1} \times P_{2}\right)$. A letra $(n)$ representa o número de motivos repetidos do loco amplificado.

2 Esquema de retrocruzamentos utilizado para a obtenção de linhagem isogênica convertida ( $\mathrm{L} 30 \mathrm{HtH})$

3 Comparação entre protocolos de amplificação nos programas 1/ $0,165 \mu \mathrm{M}$ de "primer" (A); 1/0,33 $\mu \mathrm{M}$ (B); 1/1,00 $\mu \mathrm{M}$ (C) e 2/0,33 $\mu \mathrm{M}$ (D) com o loco de microssatélite PHI033; nos programas $1 / 0,165 \mu \mathrm{M}$ (E), 4/0,165 $\mu \mathrm{M}(\mathrm{F}), 4 / 0,33 \mu \mathrm{M}$ (G) com o loco MACE01C01 e; $1 / 0,165 \mu \mathrm{M}(\mathrm{H})$ e $1 / 0,33 \mu \mathrm{M}(\mathrm{I})$ com o loco BNGL398. Protocolos foram testados para a variedade L10HtHt e as linhagens (1), L30HtHt (2), L30htht (3) e L30Htht (4)

4 "Primers" que amplificam regiões de microssatélites em (1): parental doador L10HtHt (PD), (2): linhagem convertida L30HtHt (LQI), (3): parental recorrente L30htht (PR) e (4): hibrido L30Htht, indicando contrastes alélicos entre L10HtHtL30htht e L30htht/L30HtHt e igualdades alélicas entre $\mathrm{L} 10 \mathrm{HtH} / \mathrm{L} 30 \mathrm{HtHt}$, para os locos marcadores BNGL198 e MAG01F03 
5 Genoma das linhagens isogênicas recorrente L30htht (PR) $€$ convertida L30HtHt (LQI); em branco, segmentos cromossômicos provenientes de L30htht e; em preto, segmentos introgredidos do parental doador $\mathrm{L} 10 \mathrm{HtH}$ (PD). Contraste alélico entre PR/LQI representado por marcadores ligados (positivos) e não ligados (falsos positivos) ao gene $H t$.

6 Polimorfismos de comprimento entre dois "bulks" constituídos por individuos suscetíves ("bulk" $S_{5}$ ) e totalmente resistentes ("bulk" $R_{1}$ ) revelados por dois marcadores microssatélites (BNGL198 e MAG01F03) ligado ao gene $H t$ de resistência a $E$. turcicum

7 Genotipagem de indivíduos $R C_{1} F_{1}$ suscetiveis $\left(S_{5}\right)$ com BNGL198 ("bin" 2.08) que amplifica genótipos heterozigotos recombinantes $\left(M_{1} M_{2}\right)$ para alelos marcadores $M_{1}$ de L30HtHtRtRt (1) e $M_{2}$ de L40hthtrtrt (2) e genótipos homozigotos parentais $\left(M_{2} M_{2}\right)$ para alelo marcador $M_{2}$. Indivíduos $\mathrm{F}_{1}$ (L30HtHtRtRt $\times$ L40hthtrtrt) com genótipo marcador heterozigoto $M_{1} M_{2}(3)$

8 Genotipagem de indivíduos $\mathrm{RC}_{1} \mathrm{~F}_{1}$ suscetíveis $\left(\mathrm{S}_{5}\right)$ com MAG01F03 ("bin" 2.08) que amplifica genótipos heterozigotos recombinantes $\left(M_{3} M_{4}\right)$ para alelos marcadores $M_{3}$ de L30HtHtRtRt (1) e $M_{4}$ de L40hthtrtrt (2) e genótipos homozigotos parentais $\left(M_{4} M_{4}\right)$ para alelo marcador $M_{4}$. Indivíduos $\mathrm{F}_{1}$ (L30HtHtRtRt $\mathrm{L}$ L40hthtrtrt) com genótipo marcador heterozigoto $M_{3} M_{4}(3)$ 
9 Mapa de ligação do cromossomo $2 \mathrm{~L}$ mostrando a região próxima ao gene $H t$ derivado de $L 30 H t H t R t R t$. As distâncias entre o referido gene e os marcadores BNGL198 e MAG01F03 foram estimadas em centimorgans mediante a função de mapeamento de Haldane (1919) e a posição dos mesmos em relação a UMC49a foi obtida do mapa consenso de milho.............................................

10 Reação das linhagens diferenciadoras $\mathrm{Pa}, \mathrm{PaHt}, \mathrm{Pa} H t_{2}, \mathrm{~Pa} H t_{3}$, $\mathrm{Pa} H t N$, das linhagens L30HtHtRtRt (convertida), L30hthtRtRt (recorrente), L30HthtRtrt e L40hthtrtrt e dos hibridos L30HtHtRtRt x L40hthtrtrt e L30hthtRtRt $\times$ L40hthtrtrt, segundo o tipo de lesão descrito por Esteves (1989), após inoculação com os isolados 18, $47,48,49$ e 53. Tipo de reação $\left(R_{2}\right)$ : pontos cloróticos ou pequenas lesões clorótico-necróticas circulares; $\left(R_{3}\right)$ : lesões clorótico-necróticas estreitas em fase inicial de desenvolvimento; $\left(S_{5}\right)$ : lesões necróticas sem halo clorótico e delimitadas com bordo escuro na periferia e; $\left(S_{6}\right)$ : lesões necróticas sem delimitação e com a extremidade das folhas murchas e secas 


\section{LISTA DE TABELAS}

Página

1 Programas de amplificação de locos microssatélites. As primeiras e últimas fases dos ciclos são conduzidas à temperaturas constantes de $94{ }^{\circ} \mathrm{C}$ ( $T_{D}$ : temperatura de desnaturação) por 1 minuto e $72{ }^{\circ} \mathrm{C}$ ( $T_{E}$ : temperatura de extensão) por 2 minutos, respectivamente e, a fase intermediária, à temperaturas variáveis por 1 minuto $\left(T_{A}\right.$ : temperatura de anelamento) em função do programa de PCR

2 Temperaturas de anelamento e concentrações de "primers reverse/forward" (R/F) otimizadas para a amplificação de locos de microssatélites em milho.

3 Número de locos microssatélite não informativos, informativos possivelmente ligados e não ligados ao gene de resistência $(H t)$ a Exserohilum turcicum de milho

4 Análise de linhagens quase isogênicas de milho para locos microssatélites não informativos (-), informativos possivelmente não ligados $(+)$ e ligados $\left(^{*}\right)$ ao gene de resistência $(H t)$ a Exserohilum turcicum

5 Reação das linhagens L30HtHt, L30htht, L30Htht e L40htht e dos híbridos $F_{1} H$ tht $t^{\prime A}$ e $F_{1} h t^{\prime B}$ frente a cinco isolados de $E$. turcicum, coletados nas Regiões Sul, Sudoeste e Centro-Oeste. 
6 Expressão da resistência de 138 indivíduos da população [(L30HtHt $\times$ L40htht) $\times$ L40htht], frente ao isolado 47 de Exserohilum turcicum

7 Segregação de $H t$ e $r$ quanto ao tipo de lesão sobre plantas de diferentes gerações derivadas do cruzamento de L30HtHt (parental $\left.P_{1}\right) \times$ L40htht (parental $P_{2}$ ), linhagens L30Htht $\left(P_{3}\right)$ e L30htht $\left(P_{4}\right)$ e geração $F_{1}$ resultante do cruzamento de $\left(P_{1}\right)$ e $\left(P_{4}\right)$ com L40htht frente ao isolado 47 . Individuos $R_{1}, R_{2}, R_{3}$ e $R_{4}$ foram agrupados dentro da classe dos resistentes $(R)$ e $S_{5}$ e $S_{6}$ dentro da classe dos suscetiveis (S)

8 Teste de ligação genética entre o gene de resistência $H t$ e os marcadores BNGL198 e MAG01F03 ("bin" 2.08) na população segregante [(L30HtHtRtRt $\times$ L40hthtrtrt) $\times$ L40hthtrtrf .

9 Reação das linhagens diferenciadoras $\mathrm{Pa}, \mathrm{Pa} H t_{1}, \mathrm{~Pa} H t_{2}, \mathrm{~Pa} H t_{3}$, $\mathrm{Pa} H t N$, das linhagens L30HtHtRtRt (convertida), L30hthtRtRt (recorrente), L30HthtRtrt e L40hthtrtrt e dos hibridos L30HtHtRtRt $x$ L40hthtrtrt e L30hthtRtRt $\times$ L40hthtrtrt, inoculados com cinco isolados de Exserohilum turcicum, provenientes de São Paulo (isolados 18, 47 e 53), Mato Grosso do Sul (isolado 48) e Paraná (isolado 49). 


\title{
IDENTIFICAÇÃO E LOCALIZAÇÃO DE UM GENE DE RESISTÊNCIA DE MILHO A Exserohilum turcicum (Pass.) Leonard \& Suggs. ATRAVÉS DO USO DE MARCADORES MICROSSATÉLITES
}

\author{
Autora: JULIANA BERNARDI OGLIARI \\ Orientador: Prof. Dr. LUIS EDUARDO ARANHA CAMARGO
}

\section{RESUMO}

A incorporação de genes de resistência qualitativa é uma importante estratégia de controle da helminthosporiose do milho. No presente estudo, a comparação entre um par de linhagens quase isogênicas - LQIs (Muehlbauer et al., 1988 e Young et al., 1988), que diferem pela presença de um gene de resistência a $E$. turcicum, foi a estratégia adotada para identificar marcadores microssatélites ligados a esse loco. A análise genética de LQIs também permitiu avaliar a recuperação do genoma do parental recorrente na linhagem convertida da geração $R_{6} S_{1}$. Para tanto, as linhagens convertida $\mathrm{L} 30 \mathrm{HtHt}$, doadora $\mathrm{L} 10 \mathrm{HtH}$ e recorrente $\mathrm{L} 30 \mathrm{htht}$ foram genotipadas para 125 locos de microssatélites, dentre os quais 61 foram informativos. A evidência de ligação entre o gene $H t$ introgredido e cada loco marcador analisado foi obtida pela presença de contrastes alélicos entre as linhagens recorrente e convertida e de igualdades alélicas entre esta última e o parental doador do gene de resistência. Dentre os marcadores informativos, cinco locos previamente mapeados nos cromossomos 2 (BNGL198 e MAG01F03), 5 (PHI113 e MACE01A03) e 6 (MACTO2E01) revelaram polimorfismos entre L30HtHt e L30htht, sugerindo que qualquer uma dessas regiões poderiam ser portadoras do gene $H t$. A percentagem observada de $8,20 \%$ do genoma do parental doador retida na linhagem convertida praticamente correspondeu ao limite superior esperado de $7,66 \%$, estimado pelo procedimento aplicado por Muehlbauer et al. (1988). A correspondência entre as quantidades esperadas e 
observadas de cinco marcadores do parental doador retidos no genoma da linhagem convertida e de dois retidos próximo a região que contém o gene introgredido, confirmou a validade da análise de linhagens quase isogênicas mediante marcadores microssatélites. A eliminação dos marcadores falsos positivos dentre os cinco locos identificados pela análise de LQIs foi efetuada pela análise dos segregantes agrupados - ASA (Michelmore et al., 1991), após a fenotipagem de 138 individuos segregantes da população [(L3OHtHt $x$ L40htht) $\times$ L40htht]. Indivíduos pertencentes aos grupos extremos de resistência e suscetibilidade foram genotipados para cada um dos cinco marcadores positivos (BNGL198, MAG01F03, PHI113, MACE01A03 e MACT02E01). O padrão de bandeamento de BNGL198 e MAG01F03, ambos localizados no braço longo do cromossomo 2 ("bin" 2.08), indicaram ligação putativa ao gene Ht sob análise. A confirmação da suposta ligação entre esse gene e os dois marcadores, bem como as distâncias genéticas correspondentes foram estimadas com base na análise de segregação dos indivíduos extremos da classe recessiva (Zhang et al., 1994) da mesma população [(L30HtHt x L40htht) $x$ L40htht] e mostrou que o loco $\mathrm{Ht}$ está a cerca de $28,77 \mathrm{cM}$ e $23,50 \mathrm{cM}$ de BNGL198 e MAG01F03, respectivamente. Testes envolvendo a inoculação de cinco isolados brasileiros de E. turcicum sobre um conjunto de linhagens isogênicas portadoras de diferentes genes de resistência a helminthosporiose, permitiram verificar que o gene $H t$, aqui designado $H t P$, é um novo gene ou uma forma alélica alternativa do já descrito gene $H t_{1}$. HtP confere resistência às raças portadoras de amplo espectro de virulência (123

e 23r) e, portanto, recomenda-se a sua introgressão em cultivares híbridas e variedades comerciais de milho nacionais. 


\title{
IDENTIFICATION AND MAPPING OF A Exserohilum turcicum \\ (Pass.) Leonard \& Suggs RESISTANCE GENE IN MAIZE USING MICROSATELLITE MARKERS
}

\author{
Author: JULIANA BERNARDI OGLIARI \\ Adviser: Prof. Dr . LUIS EDUARDO ARANHA CAMARGO
}

\section{SUMMARY}

The incorporation of quantitative resistance genes is an important strategy for controlling corn helminthosporiosis. In this study a comparison between a pair of near isogenic lines - NILs (Muehlbauer et al., 1988 and Young et al., 1988), which differ by the presence of a resistance gene to $E$. turcicum, was the strategy adopted for identifying microsatellite markers linked to this locus. The genetic analysis of NILs also permitted evaluating the recovery of the genome of the recurrent parent in the converted line of generation $\mathrm{RC}_{6} \mathrm{~S}_{1}$. For this, the converted $\mathrm{L} 30 \mathrm{HtH}$, the donor $\mathrm{L} 10 \mathrm{HtHt}$, and the recurrent $\mathrm{L} 30 \mathrm{htht}$ lines were genotyped with 125 microsatellite loci, 61 of which were informative. The evidence of linkage between the introducted $H t$ gene and each marker locus analysed was obtained by the presence of allelic contrasts between the recurrent and converted lines and of allelic equalities between the latter and the parental donor of the resistance gene. Among the informative markers, five previously mapped loci in chromosomes 2 (BNGL198 and MAG01F03), 5 (PHI113 and MACE01A03), and 6 (MACTO2E01) revealed polymorphisms between L3OHtHt and L3Ohtht, suggesting that any one of these regions could contain the gene $\mathrm{Ht}$. The observed percentage of $8.20 \%$ of the parental donor genome retained in the converted line practically corresponded to the expected upper limit of $7.66 \%$, estimated by the procedure applied by Muehlbauer et al. (1988). The correspondence between the expected quantities and those 
observed of five markers of the parental donor retained in the converted line genome and of two retained close to the region which contains the introducted gene confirmed the validity of the analysis of near isogenic lines using microsatellites. The elimination of false positive markers among the five loci identified by the analysis of the NILs was effected through bulked segregant analysis - BSA (Michelmore et al.,1991) after phenotyping 138 segregant individuals of the population [(L30HtHtRtRt $\times$ L40hthtrtrt) $\times$ L40hthtrtrf]. Individuals belonging to groups of extreme resistance and susceptibility were genotyped for each of the five positive markers (BNGL198, MAG01F03, PHI113, MACE01A03 and MACTO2E01). The banding pattern of BNGL198 and MAG01F03, both located in the long arm of chromosome 2 ("bin" 2.08) indicated putative linkage to the $\mathrm{Ht}$ gene under analysis. The confirmation of the putative linkage between this gene and the two markers, as well as the corresponding genetic distance, were estimated based on the segregation analysis of individuals of the recessive class (Zhang et al., 1994) of the same population [(L30HtHtRtRt $\times$ L40hthtrtrt) $\times$ L40hthtrtrt] and showed that the locus $H t$ is at approximately $28.77 \mathrm{cM}$ and $23.50 \mathrm{cM}$ of BNGL198 and MAG01F03, respectively. Tests involving the inoculation of five Brazilian isolates of $E$. turcicum on a group of isogenic lines containing different helminthosporiosis resistance genes permitted verifying that the gene $H t$, herein designated $H t P$, is a new gene or an alternative allelic form of the formerly described gene $H t_{1}$, which confers resistance to races containing a wide virulence spectrum (123 and 23r). The introgression of HtP in hybrid cultivars and comercial varieties of Brazilian corn is recommended. 


\section{INTRODUÇÃO}

Dentre as principais doenças foliares que afetam a cultura do milho, destaca-se a helminthosporiose ou requeima das folhas, causada por Exserohilum turcicum (Pass.) K.J. Leonard \& E.G. Suggs. [Helminthosporium turcicum Pass.], cujo estádio perfeito corresponde a Setosphaeria turcica (Luttrell) K.J. Leonard \& E.G. Suggs. (Frederiksen,1991) [Trichometasphaeria turcica Luttrell]. Essa doença está amplamente disseminada em todas as regiōes de cultivo de milho do mundo. No Brasil, epidemias ocorrem com maior freqüência nas Regiões Sul e Chapadas da Região Centro-Oeste, causando severos prejuízos. Em condições de temperaturas entre 20 e $25{ }^{\circ} \mathrm{C}$, umidade relativa de 90 a $100 \%$ e baixa luminosidade (Bentolila et al., 1991; Levy, 1991), a helminthosporiose afeta significativamente a produção, tanto qualitativa como quantitativamente (Lopes, 1987), além de predispor a planta a podridão de colmo causada por Diplodia maydis (Raymundo \& Hooker, 1981).

Embora a helminthosporiose seja de ocorrência esporádica (Bentolila et al., 1991 e Esteves, 1989), as perdas em produção de grãos podem chegar a $50 \%$ ou mais (Hooker, 1975; Perkins \& Pedersen, 1987; Raymundo \& Hooker, 1981), como conseqüência de extensas desfolhas durante o período de enchimento de grãos, principalmente se a infecção ocorrer antes do florescimento (Carson \& Van Dyke, 1994 e Raymundo \& Hooker, 1981).

Segundo observações de Smith \& Kinsey (1980), o controle da helminthosporiose é conseguido pelo uso de germoplasma resistente, cuja forma de controle é considerada a mais econômica. A incorporação de genes 
simples de resistência compreende uma importante estratégia de controle desta doença a curto prazo, até que sejam estabelecidos níveis adequados de resistência quantitativa para que, posteriormente, sejam utilizados em conjunto. Contudo, devido as inúmeras dificuldades inerentes ao processo de seleção de genótipos resistentes (Melchinger, 1990; Miklas et al., 1993; Penner et al., 1993; Stavely et al., 1989; Tanksley et al., 1989 e Tingey \& Tufo, 1993), a seleção orientada por marcadores moleculares passa a ser uma importante ferramenta de auxílio dentro dos programas de melhoramento, ainda que se esteja trabalhando com genes de grande efeito fenotípico.

Para a realização das análises moleculares do presente estudo, inicialmente foi necessária a otimização de protocolos para a amplificação de 125 locos de microssatélites de milho. A comparação entre um par de linhagens quase isogênicas ("near isogenic lines"; Muehlbauer et al., 1988 e Young et al., 1988) que diferem por um gene de resistência a $E$. turcicum, permitiu estimar a recuperação do genoma do parental recorrente na linhagem convertida. Adicionalmente, a análise de linhagens quase isogênicas associada a análise dos extremos agrupados ("bulk segregant analysis"; Michelmore et al., 1991) de uma população segregante $R C_{1} F_{1}$ foram as estratégias adotadas para identificar marcadores microssatélites ligados ao referido gene de resistência. $A$ confirmação da ligação entre esse gene e locos marcadores putativamente ligados, bem como a distância genética em relação aos mesmos, foi efetuada pela genotipagem dos indivíduos extremos da classe recessiva (Zhang et al., 1994). Finalmente, também foram conduzidos testes envolvendo a inoculação de cinco isolados brasileiros de $E$. turcicum sobre um conjunto de linhagens isogênicas portadoras de diferentes genes de resistência a helminthosporiose, visando-se identificar o espectro de resistência conferido pelo gene $\mathrm{Ht}$ sob análise. 


\section{REVISÃO DE LITERATURA}

\subsection{PatossistemaZea mays/Exserohilum turcicum}

\subsubsection{Resistência monogênica}

O uso de germoplasma resistente é considerado um método de controle satisfatório da helminthosporiose do milho. Em geral, essa resistência genética pode ser classificada em dois tipos: qualitativa ou de genes maiores e quantitativa ou parcial (Gevers, 1975; Hooker,1963a; Hooker, 1975; Hooker, 1977; Hooker, 1981; Hughes \& Hooker, 1971; Pataky et al., 1986; Raymundo \& Hooker, 1982). Até a década de 60 , a resistência quantitativa foi o principal tipo de resistência a helminthosporiose utilizado, tendo como principais atributos um modelo de herança, em geral, poligênica (Jenkins \& Robert, 1952; Jenkins \& Robert, 1959; Raymundo \& Hooker, 1982) e de dificil transferência para novos genótipos (Hooker \& Kim, 1973).

Devido a crescente importância desta doença, numerosas avaliações passaram a buscar novas e/ou adicionais fontes de resistência. A partir disso, vários genes de grande efeito dominantes ou parcialmente dominantes foram descritos $\left(H t_{1}, H t_{2}, H t_{3}\right.$ e $\left.H t N, H t M\right)$ (Gevers, 1975; Hooker, 1961, 1963a, 1963b, 1975, 1977, 1978; Robbins \& Warren, 1993) como capazes de conferir resistência qualitativa expressa por diferentes tipos de lesões (Hilu \& Hooker, 1964; Hooker, 1963a), freqüentemente cloróticas (Hooker, 1980). Recentemente, Carson \& Wicks (1993) identificaram um outro loco gênico, cuja resistência se manifesta apenas quando presente na condição recessiva. 
O gene dominante $\mathrm{Ht}_{1}$ (Hooker 1963b) foi o primeiro a ser descrito na literatura (Hooker, 1961). Posteriormente, uma série de outras linhagens estudadas por Hooker (1980) mostrou a existência de dois alelos de resistência para esse mesmo loco. Em 1977, foi descoberto o gene $H t_{2}$, que segrega independentemente de $H t_{1}$ (Hooker, 1977 e 1980) e que não se expressa em genótipos portadores do gene dominante inibidor "l" (Caballos \& Gracen, 1989). Adicionalmente, ainda foram identificados os genes $\mathrm{Ht}_{3}$, derivado de Tripsacum floridanum (Hooker, 1975; Hooker, 1981), um gene recessivo do milho sintético BS 19 (Carson \& Wicks, 1993) e, finalmente, os genes HtN (Gevers, 1975) e HtM (Robbins \& Warren, 1993), que também segregam independentemente de $H t_{1}$.

O gene $H t_{1}$, localizado no braço longo do cromossomo 2, foi o primeiro loco qualitativo a ser mapeado mediante técnicas convencionais (Patterson et al. 1963 e 1965). Com o desenvolvimento das técnicas de marcadores moleculares, foram ampliadas as possibilidades de mapeamento em inúmeras espécies de plantas. Nesses últimos dez anos, um grande número de genes qualitativos e locos de caracteres quantitativos (QTLs), responsáveis pela resposta da planta à pragas e patógenos, foram mapeados em milho (McMullen \& Simcox, 1995) e complementaram as informações conseguidas através das técnicas de mapeamento convencionais. Atualmente, a localização de genes no mapa é efetuada com base na posição de "bins" cromossômicos, os quais representam subdivisões do cromossomo constituídas por segmentos de cerca de $20 \mathrm{cM}$ delimitados por marcadores RFLPs de posição conhecida (McMullen \& Simcox, 1995). A posição de um "bin" é dada por um código numérico, onde o primeiro número corresponde ao grupo de ligação ao qual o "bin" pertence e o segundo, a posição do "bin" dentro do grupo de ligação. Com base nisso, o gene de resistência $H t_{1}$ foi posicionado a $168 \mathrm{cM}$ do ponto zero do cromossomo 2 (Bentolila et al. 1991; Coe, et al. 1995; Gardiner, 1993; Ma, 1991), dentro do "bin" 2.08 (McMullen \& Simcox, 1995). Já os genes de resistência não alélicos $H_{2}$ e $H t N$, no "bin" 8.06 do cromossomo 8 , a cerca de 
10 cM de distância um do outro (Simcox \& Bennetzen, 1993; Zaitlin et al., 1992) e próximos a QTLs responsáveis pela resistência a $E$. turcicum que ocupam a região correspondente ao "bin" 8.03 a 8.04 (McMullen \& Simcox, 1995) e 8.05 (Helentjaris, 1995). A localização de $H t_{3}$ e $H t M$ ainda não foi publicada, apesar de análises conduzidas com marcadores RFLPs (Simcox \& Bennetzen, 1993) confirmarem os resultados preliminares obtidos por Hooker (1981), quanto a segregação independente do primeiro em relação aos genes $H t_{1}$ ("bin" 2.08), $H_{2}$ e HtN ("bin" 8.06"). Segundo Simcox \& Bennetzen (1993), a similaridade de expressão fenotípica de $\mathrm{Ht}_{2}$ e $\mathrm{Ht}_{3}$ sugere que o gene $\mathrm{Ht}_{3}$ de Tripsacum é homólogo ao gene $\mathrm{Ht}_{2}$ de milho. Entretanto, a ausência de ligação entre os dois é uma indicação de que o segmento cromossômico portador de $\mathrm{Ht}_{3}$ foi integrado num sítio não homólogo no genoma de milho. Mais recentemente, a posição do gene recessivo identificado por Carson \& Wicks (1993), efetuada com base em estudos de mapeamento envolvendo translocações reciprocas (Carson, 1995), foi determinada no braço curto do cromossomo 1, próximo ao centrômero.

Estudos recentes, envolvendo estratégias de análise molecular têm contribuido para elucidar a existência de apenas um tipo de gene de resistência. Um aspecto interessante do trabalho de Freymark et al. (1993) refere-se, justamente, a comparação da localização de QTLs com locos conhecidos ( $H t_{1}$ e $H t_{2}$, por exemplo) de efeito qualitativo. No referido estudo, regiōes cromossômicas contendo os locos $H t_{1}$ e $H t_{2}$ mostram uma pequena contribuição na determinação do tamanho de lesão, ainda que nunca tenham sido registrados alelos dominantes de grande efeito qualitativo em nenhum dos parentais envolvidos na geração da população estudada. Tal fato sugere que a localização dos genes de efeito qualitativo pode coincidir com aquela atribuida às regiões que manifestam efeitos relativamente mais modestos detectados nos estudos de Freymark et al. (1993). Com base nesses resultados, os autores concluem que locos da mesma região de $H t_{1}$ e $H t_{2}$ apresentam um pequeno efeito na ausência dos significativos efeitos qualitativos dos referidos genes. 
Eles ainda destacam a possibilidade desses fatores qualitativos $\left(H t_{1}\right.$ e $\left.H t_{2}\right)$, serem formas alélicas alternativas ou mesmo alelos mutantes dos locos com efeitos quantitativos, de forma a comporem a extremidade oposta dentro de um espectro de isoalelos.

\subsubsection{Expressão fenotípica dos genes $\mathrm{Ht}$}

A resistência raça especifica conferida pelos genes $H t_{1}, H t_{2}$ e $H t_{3}$ manifesta-se mediante uma reação de hipersensibilidade, caracterizada por lesões clorótico-necróticas com limitada esporulação nos centros necróticos (Hilu \& Hooker, 1964; Hooker \& Kim, 1973; Leonard et al. 1989). Particularmente, a resistência do gene $\mathrm{Ht}_{1}$ condiciona o aparecimento de lesões cloróticas que retardam a formação de áreas necróticas na região central das mesmas (Hooker, 1961). Esses sintomas são acompanhados por graus variados de reduções no tamanho das lesões e quase completa supressão da esporulação, em função do "background" genético ao qual o referido gene esteja atuando (Hooker, 1963b). A resistência da linhagem "B1138T", proveniente da África do Sul, manifesta-se como pontos cloróticos que tornamse necróticos sem alongarem-se, mesmo após 5 semanas da inoculação (Hilu \& Hooker, 1965). O gene HtM, derivado de "Mayorbela", é capaz de conferir resistência quase completa a helminthosporiose (Warren, 1981 e 1982). Já o gene recessivo identificado por Carson \& Wicks (1993) manifesta-se através de pontos de infecção de coloração alaranjada escura a marron, circundados por halo clorótico de cerca de $1 \mathrm{~cm}$ de diâmetro, freqüentemente presentes até a senescência e, eventualmente, evoluindo para as típicas e alongadas lesões necróticas da helminthosporiose. Finalmente, a resistência conferida pelo gene $H t N$ é distinta da típica lesão clorótico-necrótica associada aos genes de resistência $\mathrm{Ht}_{1}, \mathrm{Ht}_{2}$ e $\mathrm{Ht}_{3}$ (Leonard et al., 1989). Tal resistência manifesta-se

pelo aumento do período entre a infecção e a expressão dos sintomas (Smith \& Kinsey, 1993), pelo atraso no desenvolvimento das lesões até depois da antese 
(Gevers, 1975; Raymundo et al. 1981), pelo atraso no início da esporulação (Simcox \& Bennetzen, 1993) e pela supressão da formação de lesões necróticas durante o período de desenvolvimento mais crítico do milho (Leonard et al., 1989).

O gene $H t N$ combinado a $H t_{1}$ num único genótipo, manifesta um fenótipo de resistência intermediário frente a isolados avirulentos de $E$. turcicum. Este tipo de reação expressa-se mediante uma lesão cloróticonecrótica menor do que aquela observada em genótipos $H t_{1}$ (Simcox \& Bennetzen, 1993). Além dessa interação entre dois genes de grande efeito, também é pertinente relatar alguns efeitos da interação entre a resistência parcial e os genes $H$ ts na expressão de alguns componentes da resistência. Em "backgrounds" genéticos mais suscetiveis, por exemplo, a resistência do gene $H t N$ se expressa como pequenas lesões do tipo suscetível que raramente esporulam e que se formam após um atraso superior a vinte e seis dias (Raymundo et al., 1981). Por outro lado, o gene $H t_{1}$ em "backgrounds" portadores de resistência parcial, manifesta-se pela reduzida esporulação e pelo pequeno número e tamanho de lesões (Jiansheng \& Jillin, 1984), indicando que o grau de resistência de materiais com genes $H$ ts é influenciado pelo nível de resistência parcial presente nos mesmos (Hooker \& Kim, 1973; Pataky, 1994; Pataky et al., 1986 e Raymundo \& Hooker, 1982)

Segundo Lipps et al. (1997), a combinação de $H t_{1}$ e resistência parcial limita o número de lesões apenas em condições epidêmicas menos severas. De forma similar, genótipos portadores apenas de resistência parcial, também apresentam esse efeito redutor sobre o número de lesões em contraste a materiais suscetíveis portadores e não portadores do gene $H t_{1}$, sob condições epidêmicas de baixa intensidade. Ainda foi observado uma redução na severidade em genótipos potadores de baixa a moderada resistência parcial, quando combinados ao gene $H t_{1}$, apesar da lesão do tipo clorótica, proveniente da expressão desse último, não limitar os prejuizos causados ao hospedeiro. Isso indica que não há vantagens em associar a resistência conferida pelo gene 
$H t$ a materiais portadores de alto nível de resistência parcial, em locais onde as condições epidêmicas são freqüentes e severas.

As resistências monogênica e parcial sozinhas têm prevenido quantidades significativas de infecção causada por E. turcicum em áreas temperadas (Pataky et al., 1986; Raymundo \& Hooker, 1982), embora a resistência qualitativa não seja efetiva contra todas as raças do patógeno. Entretanto, é preferivel a combinação da resistência poligênica, que reduz o número de lesões produzidas, e da monogênica que suprime a esporulação. Essa última é mais ou menos efetiva em função do alelo $H t$ envolvido; mas de qualquer forma, as combinações de genes $H$ ts entre si e com outras formas de resistência possivelmente aumentam a estabilidade e durabilidade da resistência contra $E$. turcicum.

O efeito do ambiente sobre a expressão da resistência qualitativa a helminthosporiose frente a raças avirulentas também tem sido amplamente documentado na literatura (Leath et al., 1987; Thakur et al., 1989a). Thakur et al. (1989a), por exemplo, relataram a quebra da resistência do gene $\mathrm{Ht}_{2}$ pela raça 0 (antiga raça 1) em decorrência da baixa intensidade de luz oferecida durante 0 ensaio. Outros trabalhos estudaram o efeito do ambiente sobre a expressão da virulência, pré e pós-inoculação, diante de genes de resistência inefetivos. A virulência da raça 1 (antiga raça 2) sobre plântulas portadoras do gene $H t_{1}$, e das raças 23 (antiga raça 3) e $23 \mathrm{~N}$ (antiga raça 4) sobre a resistência conferida por $\mathrm{Ht}_{3}$ foi melhor expressa em temperaturas de $22{ }^{\circ} \mathrm{C}$ (dia) $/ 18^{\circ} \mathrm{C}$ (noite), particularmente sob reduzida intensidade de luz (Leath et al., 1990; Thakur et al., 1989a e; Thakur et al., 1989b). A virulência da raça 1 se manteve em condições de temperaturas mais elevadas naquelas plantas que foram inicialmente desenvolvidas, inoculadas e resguardadas em temperaturas mais amenas $\left(2{ }^{\circ} \mathrm{C} / 18^{\circ} \mathrm{C}\right.$ ) até seis dias ou mais da inoculação (Thakur et al., 1989b). Outrossim, as raças 23 e $23 \mathrm{~N}$ tiveram a virulência comprometida em condiçōes de temperaturas de $26^{\circ} \mathrm{C} / 22^{\circ} \mathrm{C}$ (Thakur et al., 1989a).

Os estudos comentados acima demonstram que as reações asso- 
ciadas a resistência monogênica e a virulência são sensíveis às variações na intensidade de luz e temperatura, o que torna necessária a condução de experimentos em condições controladas de ambiente que permitam a maximização da expressão de ambas (resistência/virulência). Com essa finalidade, Leonard et al. (1989) sugerem que as plantas de milho devem crescer em temperaturas moderadas próximas a $20^{\circ} \mathrm{C}$ e sob condições de baixa intensidade luminosa.

\subsubsection{Variabilidade patogênica}

Tradicionalmente, os programas de melhoramento têm enfatizado a incorporação de genes simples de resistência contra as raças predominantes de uma dada região produtora. A partir do conhecimento prévio da vulnerabilidade potencial deste tipo de resistência em função de mudanças na virulência do patógeno, justifica-se investigar a especialização fisiológica de $E$. turcicum (Hooker, et al., 1965; Berquist \& Masias, 1974; Leonard et al., 1989; Smith \& Kinsey, 1980; Thakur et al., 1989a; Windes \& Pedersen, 1991).

Os primeiros estudos envolvendo genótipos portadores de resistência monogênica a diversos isolados de $E$. turcicum indicaram uma avirulência uniforme destes em plantas contendo o gene $\mathrm{Ht}_{1}$ (Hooker et al., 1965). Entretanto, em 1974, foi encontrada a primeira raça capaz de superar os mecanismos de resistência conferidos por $H t_{1}$, mas incapaz de superar aqueles conferidos por $\mathrm{Ht}_{2}$ (Berquist \& Masias, 1974). Essa raça, inicialmente designada raça 2 e, posteriormente, renomeada pelo sistema proposto por Leonard et al. (1989) como raça 1 , foi representada pela fórmula de virulência $H t_{2} / H t_{1}$ (genes efetivos/inefetivos). Posteriormente, raças adicionais de $E$. turcicum foram identificadas como capazes de superar não apenas o gene $H t_{1}$, mas também $\mathrm{Ht}_{2}$ e $\mathrm{HtN}$, individualmente ou em várias combinações (Gianasi et al., 1997; Leonard et al., 1989; Pieczarka, 1980; Smith \& Kinsey, 1980; Thakur et al., 1989a; Welz \& Geiger, 1993; Windes \& Pedersen, 1991). 
Dentre as raças mais comuns identificadas na América do Norte, as raças 0 e 1 são relativamente mais freqüentes (Fallah Moghaddam \& Pataky, 1994), enquanto as raças 23 (Jordan et al., 1983 e Lipps \& Hite, 1982), 2N e 23N (Fallah Moghaddam \& Pataky, 1994) são comparativamente mais raras. Uma explicação para isso seria que a resistência a helminthosporiose conferida pelo gene $H t_{1}$ tem sido extensivamente usada nas áreas de produção comercial de milho doce dos EUA, ao contrário dos genes $\mathrm{Ht}_{2}, \mathrm{Ht}_{3}$ e $\mathrm{HtN}$ (Fallah Moghaddam \& Pataky, 1994).

No Brasil, alguns dos primeiros trabalhos conduzidos com o intuito de identificar raças fisiológicas de $E$. turcicum detectaram apenas um comportamento diferenciado entre isolados, o que sugeriu apenas a presença de raças fisiológicas (Esteves, 1989; Heidrich-Sobrinho \& Hermes, 1981). Recentemente, Gianasi et al. (1996) identificaram uma ampla variabilidade genética desse patógeno $(0,2, N, 1 \mathrm{~N}, 2 \mathrm{~N}, 3 \mathrm{~N}, 12 \mathrm{~N}, 23 \mathrm{~N}$ e $123 \mathrm{~N})$ mediante a caracterização de 25 isolados coletados em diferentes regiōes produtoras de milho das Regiões Sul, Sud este e Centro-Oeste do País (RS, SC, PR, SP, MG e MS). A partir das reações produzidas em um conjunto de cinco linhagens diferenciadoras, os autores observaram um predomínio da raça 0 e uma menor freqüência dos isolados identificados como capazes de vencer a resistência condicionada pelo gene $H t_{1}(1 \mathrm{~N}, 12 \mathrm{~N}$ e $123 \mathrm{~N})$.

É interessante ressaltar que a relação gene-a-gene também ocorre para o sistema Zea mays/E. turcicum. Em 1974, Lim e colaboradores constataram que a progênie resultante de um cruzamento entre isolado virulento (raça 1) e avirulento (raça 0) de E. turcicum, quando inoculada na fonte de resistência monogênica $H t_{1}$, segrega na proporção $1: 1$, indicando que a herança da virulência no patógeno também é monogênica. Faltah Moghaddam \& Pataky (1994) chegaram às mesmas conclusões e adicionaram uma possível ligação entre alguns genes de virulência de E. turcicum, após estudarem a segregação da progênie derivada do cruzamento entre as raças 1 e $23 \mathrm{~N}$. 
A incorporação de monogenes de resistência qualitativa $(H t)$ em milho é um procedimento recomendável a ser adotado pelos programas de melhoramento em conjunto a outras formas de controle genético mais complexas, pois a durabilidade desses genes, em alguns casos, pode ser relativamente longa. $\mathrm{O}$ gene $H t_{1}$, por exemplo, controlou eficientemente a helminthosporiose por mais de 15 anos (Leath et al., 1990) nos EUA. Outrossim, deve ser considerado o efeito residual ainda conferido por esses genes, mesmo após terem sido superados por uma nova raça do patógeno (Clifford, 1975 e Leath \& Pedersen,1984 e 1986; Nelson, 1978 e 1979).

\subsection{Marcadores moleculares aplicados a seleção da resistência monogênica}

A seleção de genes de resistência qualitativa pode ser dificultada por inúmeros fatores, dentre os quais destacam-se: - à prática de inoculação natural, especialmente para certas doenças causadas por patógenos de solo e nematóides; - à introgressão de genes recessivos via sucessivos retrocruzamentos, devido a necessidade de gerações adicionais com testes de progênies; - ao significativo efeito do ambiente sobre alguns componentes da resistência, inclusive aqueles controlados pela herança qualitativa; - ao estádio avançado de desenvolvimento da planta para a expressão da resistência à certas doenças; - à falta de raças capazes de discriminar genes específicos presentes em novas fontes de resistência ou em genótipos submetidos a seleção; - à seleção contra o "background" genético do parental doador do gene de resistência e;- à presença de interações epistáticas e de dominância, mesmo quando estejam envolvidos apenas genes de resistência de grande efeito, facilmente identificados (Barua et al., 1993; Melchinger, 1990; Haley et al., 1994; Miklas et al., 1993; Stavely et al., 1989).

É pertinente ressaltar que muitas dessas dificuldades podem ser superadas pela identificação direta do genótipo desejado mediante um teste 
diagnóstico baseado em polimorfismos de DNA. Com base nisso, a seleção orientada por marcadores pode ser vista como um meio prático e eficiente de desenvolver plantas resistentes, bastando apenas a escolha de marcadores que sejam fáceis de serem detectados e que estejam ligados aos fatores de resistência sob seleção (Miklas et al.,1993).

Programas de melhoramento voltados para o desenvolvimento de cultivares resistentes a patógenos ou variantes exóticas do mesmo patógeno (Miklas et al., 1993), que sejam inexistentes ou de rara ocorrência nos locais de teste, também são beneficiados pelo uso de marcadores. Na primeira situação, sua importância é óbvia, uma vez que as inoculações artificiais geralmente são proibidas devido ao risco da introdução de novas fontes de variabilidade patogênica em populações nativas. Por outro lado, quando a ocorrência do patógeno é errática numa dada região, a seleção indireta por marcadores pode garantir um progresso consistente em todos os ciclos de seleção.

Naqueles casos onde o fenótipo resistente somente se expressa em estádios avançados de desenvolvimento da planta, a seleção orientada via marcadores moleculares também pode ser de inestimável valor, uma vez que viabiliza a seleção de genótipos resistentes nos primeiros estádios de desenvolvimento da planta (Melchinger,1990), especialmente para aquelas espécies que possuem um longo intervalo entre gerações e um alto custo de cultivo por planta.

Embora o método do retrocruzamento seja considerado eficiente para a transferência de caracteres monogênicos, sua maior limitação é o tempo requerido para a recuperação dos genes desejáveis do parental recorrente, particularmente na região próxima ao gene de interesse. Nesse último caso, estudos teóricos e experimentais (Bai et al., 1995; Chyi et al., 1989; Gupta et al., 1989; Stam \& Zeven, 1981) têm mostrado que, mesmo após várias gerações de retrocruzamentos, o gene alvo continua flanqueado por fragmentos de comprimento considerável, provenientes do parental doador ("linkage drag"). 0 uso de marcadores moleculares permite uma eficiente eliminação do 
"background" genético do parental doador dos genes de resistência, principalmente se o mesmo for uma espécie selvagem ou um germoplasma não adaptado (Tanksley \& Rick, 1980 e Young \& Tanksley, 1988). Mediante a identificação de marcadores adjacentes ao gene alvo, é possível selecionar tipos recombinantes, contendo o mínimo desses segmentos próximo à região portadora desse gene, dentro de um número aceitável de retrocruzamentos.

Ferreira \& Grattapaglia (1995) comentam que um dos maiores problemas em programas de melhoramento para resistência à doenças está no manuseio e avaliação da interação fenotípica de dois ou mais patógenos sistêmicos infectando um único indivíduo ao mesmo tempo, uma vez que a infecção concomitante sempre torna difícil, se não impossível, a seleção de genótipos resistentes a múltiplos patógenos. Paralelamente, Penner et al. (1993) salientam que a reação cruzada de genes de resistência a várias raças de um mesmo patógeno também pode confundir o processo de discriminação fenotípica do hospedeiro, uma vez que nem sempre estão disponiveis as raças que podem permitir a diferenciação de genes de resistência específica. Em ambos os casos, é óbvia a utilidade dos marcadores moleculares para a identificação e subseqüente seleção de genótipos resistentes.

A introdução de mais de um gene de resistência em um único genótipo tem sido a estratégia adotada pelos programas de melhoramento para reforçar a durabilidade da resistência. Porém, o tempo requerido para as avaliações fenotípicas dos genótipos melhorados frente a diferentes raças e a demanda do produtor por cultivares resistentes tem resultado na geração de novas cultivares portadoras de um único gene de resistência qualitativa. Por todas essas razões, é importante destacar os benefícios advindos com o uso dos marcadores moleculares em programas de introgressão via retrocruzamento, seja para monitorar a presença dos genes piramidados num único germoplasma suscetível, seja durante o desenvolvimento de cultivares multilinhas, constituídas por uma mistura de isolinhas cada qual portadora de um gene de resistência (Hillel et al., 1990 e 1993; Melchinger, 1990 e Miklas et 
al., 1993) ou, ainda, na composição de cultivares portadoras de um único gene qualitativo conhecido.

É ainda mais laboriosa a detecção simultânea de genes de resistência piramidados que são testados com patotipos portadores de diferentes requerimentos de temperatura de incubação (Borovkova et al., 1995). Tais considerações, certamente, dificultam o processo de introgressão de dois ou mais genes de resistência em um mesmo cultivar, principalmente se a introgressão for efetuada com genes de efeito residual já superados pelo patógeno (Pederson \& Leath, 1988). A aplicação dos marcadores moleculares no piramidamento de genes de resistência que exibem epistasia (Haley et al., 1994; Miklas et al., 1993; Stavely et al., 1989) também é indiscutivel, dadas as dificuldades relativas aos numerosos testes de progênies requeridos para a discriminação desses genes pelos métodos tradicionais.

Mediante tais considerações, é fácil perceber as vantagens advindas do uso dos marcadores moleculares também no melhoramento de características de herança simples. No presente contexto, foram abordadas inúmeras situações onde essa técnica poderia oferecer uma solução exeqüivel e efetivamente servir como uma ferramenta auxiliar do melhoramento de plantas tradicional. A identificação de um marcador molecular ligado a um gene de resistência possibilita predizer a presença ou ausência do alelo de interesse sem ter que se basear apenas no produto resultante da sua expressão.

\subsection{Mapeamento de genes de resistência}

Para aqueles caracteres de herança Mendeliana, a localização gênica pode ser estabelecida pela análise de segregação, pela comparação de linhagens isogênicas, pela análise de segregantes agrupados e através da combinação de alguns desses métodos. Em qualquer caso, é necessária a existência de reprodução sexuada que permita a produção de descendentes em desequilíbrio de ligação e de uma fonte de marcadores moleculares que 
apresentem comportamento Mendeliano.

Quando se tem interesse por uma região particular do genoma, a comparacão de pares de linhagens quase isogênicas ("near isogenic lines") derivadas de retrocruzamentos ou de segregantes agrupados pela similalaridade fenotípica/genética dos indivíduos ("bulk segregant analysis") são as estratégias mais indicadas para a identificação de marcadores moleculares ligados.

\subsubsection{Análise genética de linhagens quase isogênicas (LQls)}

Esse método, descrito por Muehlbauer et al. (1988) e Young et al. (1988) como uma alternativa para identificar rapidamente marcadores moleculares ligados a um gene de interesse, envolve a comparação entre linhagens quase isogênicas (LQIs) que diferem entre si na região portadora do referido gene. $\mathrm{Na}$ verdade, a idéia básica dessa técnica de mapeamento genético consiste em identificar marcadores moleculares que estejam próximos ao gene de interesse mediante a determinação do genótipo marcador do parental recorrente, da linhagem isogênica convertida e do correspondente parental doador do gene. O único requisito para o seu sucesso é a existência de polimorfismos de DNA entre os parentais próximos ao gene alvo (Tingey \& Tufo, 1993).

O princípio da técnica de mapeamento de genes via LQIs parte da premissa de que o genoma da linhagem convertida é praticamente idêntico aquele do parental recorrente, após várias gerações de retrocruzamentos, com exceção da região cromossômica que contém o gene introduzido (Young et al., 1988) e de alguns outros sítios casualmente distribuídos pelo genoma. Nesse caso, supõe-se que o segmento cromossômico derivado do parental doador que flanqueia o gene introgredido deve conter marcadores moleculares em estados alélicos diferentes daqueles encontrados no parental recorrente. Por essa razão, a evidência de ligação é obtida quando a linhagem isogênica 
resistente tiver o mesmo genótipo marcador do seu parental doador, mas um genótipo marcador diferente do seu parental recorrente.

Melchinger (1990) e Young et al. (1988) ressaltam que a detecção de marcadores moleculares polimórficos entre linhagens quase isogênicas depende da extensão da diversidade molecular entre os genomas do parental recorrente e do parental doador, sendo, portanto, mais fácil encontrar polimorfismos quando os mesmos pertencem a grupos distintos, tais como as espécies cultivadas e selvagens, respectivamente. Adicionalmente, as chances de tais marcadores contrastantes serem detectados também depende do comprimento do segmento cromossômico derivado do parental doador que fica retido no parental recorrente. Alguns cálculos teóricos mostram que mesmo após 10 ou 20 gerações de retrocruzamentos, o segmento cromossômico portador do gene alvo ainda teria um comprimento de cerca de 18 ou 5 centimorgans (cM), respectivamente (Hanson, 1959; Stam \& Zeven, 1981). Isso indica que a probabilidade de encontrar marcadores contrastantes entre as LQIs tende a decrescer com o aumento do número de retrocruzamentos empregado para o desenvolvimento das mesmas (Melchinger, 1990).

Apesar da detecção de marcadores polimórficos entre a linhagem recorrente e a linhagem convertida ser uma indicação da suposta ligação destes ao gene introgredido, ainda é necessária uma confirmação pela análise de co-segregação, uma vez que uma pequena proporção dos marcadores polimórficos podem estar localizados casualmente sobre um cromossomo qualquer, diferente daquele que recebeu o gene de resistência (Young \& Tanksley, 1989 e Tingey \& Tufo, 1993). Muehlbauer et al. (1988) estimaram que dentre 100 marcadores que apresentam contrastes alélicos entre o parental recorrente e o parental doador, apenas 4 ficam retidos numa linhagem hipotética $\mathrm{RC}_{5} \mathrm{~S}_{1}$ constituída por 20 cromossomos de igual comprimento médio (50 cM). Desses 4 marcadores, 2 a 3 ficam retidos no cromossomo marcador que recebeu o gene introgredido e os demais resultam em marcadores falsos positivos. 
Adicionalmente, falsos positivos também podem ser conseqüência da retenção de extensas regiões de DNA associadas à região selecionada ("linkage drag"), durante os sucessivos retrocruzamentos. Tal fato poderia resultar na detecção de marcadores positivos ligados ao gene alvo, apesar dos primeiros estarem muito distantes do último. Nesses casos, uma análise de cosegregação entre marcador e gene de interesse simularia uma condição de segregação independente entre esses dois locos como se os mesmos não estivessem ligados, a ponto de inviabilizá-los para a seleção indireta via marcadores moleculares.

Uma das maneiras de reduzir a probabilidade $(p)$ de ocorrência desses falsos positivos seria através do incremento do número de gerações de retrocruzamentos. Nesse caso, os segmentos cromossômicos derivados do parental doador que não estão ligados ao gene alvo são reduzidos a uma maior taxa comparado ao comprimento do segmento introgredido que contém o gene alvo. Contudo, é pertinente ressaltar que a eliminação completa dos primeiros é praticamente impossível, uma vez que o número de gerações (" $t$ ") de retrocruzamentos é finito e a taxa de redução dos alelos derivados do parental doador segue uma tendência geométrica $\left[(1 / 2)^{t}\right]$ (Melchinger, 1990).

Por outro lado, ao invés de um simples par de LQIs, a inclusão de dois ou mais pares derivados de forma independente dos mesmos parentais recorrente e doador seria uma outra forma de reduzir as chances dessa fonte de erro (falsos positivos). Considerando que a probabilidade de obter o mesmo marcador falso positivo nos diferentes pares analisados é independente uma da outra, então esta seria igual a $p$ para um simples par de LQIs, $p^{2}$ para dois pares e assim por diante.

Uma outra grande limitação do emprego da estratégia de LQIs está relacionada a indisponibilidade desses materiais genéticos altamente especializados (LQIs) para a maioria das regiões do genoma de interesse potencial (Giovannoni et al., 1991), uma vez que são necessárias várias gerações de retrocruzamentos para gerar uma linhagem aproximadamente 
isogênica. Mesmo quando a obtenção desses materiais genéticos é possível, o processo acaba sendo muito demorado, laborioso e custoso.

A grande vantagem de conduzir uma análise prévia com LQIs está na redução significativa da quantidade de locos marcadores a serem analisados em testes de co-segregação, comparado a quantidade de marcadores selecionados apenas com base no polimorfismo existente entre os parentais de uma população gerada por cruzamento simples (Muehlbauer et al., 1988). Outro grande mérito está relacionado ao reduzido número de amostras analisadas por marcador, uma vez que estão envolvidos apenas três materiais genéticos, ou seja, parental doador, parental recorrente e linhagem convertida para a resistência.

Vários trabalhos foram conduzidos combinando LQIs a marcadores RFLPs (polimorfismos de comprimento de fragmentos de restrição). Young et al. (1988), por exemplo, utilizaram linhagens isogênicas na identificação de dois clones de DNA ligados ao gene $T m-2 a(0,4 \mathrm{cM})$ de tomate, que confere resistência ao vírus do TMV. Utilizando a mesma técnica, Yu et al. (1991) identificaram dois clones de DNA associados a genes de resistência a brusone do arroz. E tantos outros trabalhos em milho (Ma, 1991 e Bentolila et al., 1991), tomate (Sarfatti et al., 1989 e Van der Beek et al., 1992), soja (Diers et al., 1992) e aveia (O'Donoughue et al., 1996) também devem ser destacados como aplicações bem sucedidas dessa estratégia.

Outros trabalhos têm associado esse tipo de análise genética a marcadores RAPDs (polimorfismos de DNA amplificados aleatoriamente) isoladamente (Klein-Lankhorst et al., 1991; Mahé et al., 1995; Martin et al., 1991; Paran et al., 1991) ou em conjunto a marcadores RFLPs (polimorfismos de comprimento de fragmentos de restrição) (Miyamoto et al., 1996; Schachermayr et al., 1995), DGGEs (gradientes de desnaturação em gel de eletroforese) (Procunier et al., 1995) e SCARs (regiōes amplificadas de seqüências caracterizadas) (Adam-Blondon et al., 1994). A aplicação de AFLPs (polimorfismos de comprimento de fragmentos amplificados) também já foi 
relatada na literatura no mapeamento via LQIs do gene de resistência do mosaico da soja (Maughan et al,.1996).

\subsubsection{Análise de segregantes agrupados (ASA) e de segregantes extremos da classe recessiva}

Uma das alternativas que contorna as referidas limitações do método anterior (ocorrência de falsos positivos e não disponibilidade de LQIs) envolve a análise de misturas de DNA ("genome pooling"). Trata-se de uma estratégia usada em técnicas moleculares que identifica rapidamente regiões genômicas associadas a caracteres de herança simples ou complexa, além de detectar novos marcadores em regiões previamente mapeadas e pouco saturadas do genoma (Arnheim, 1985 e Michelmore et al., 1990).

Essa estratégia, inicialmente proposta por Arnheim et al. (1985) e, posteriormente, modificada por Michelmore et al. (1991), ficou conhecida por "bulked segregant analysis - BSA" ou análise de segregantes agrupados (ASA). Seu único pré-requisito é a existência de uma população segregante para o gene de interesse que esteja em desequilibrio de ligação em relação ao loco marcador. Assim como na técnica anterior (LQIs), o sucesso dessa estratégia depende da divergência genética entre os parentais na região alvo. Os locos que não estiverem segregando na população também não serão capazes de distinguir os "bulks", independentemente de estarem ou não ligados ao gene de interesse.

Sob o ponto de vista experimental, o método de ASA envolve comparações entre duas amostras agrupadas de DNA obtidas a partir de indivíduos extremos de uma população segregante. Os "bulks" extremos são constituídos por uma mistura de partes iguais de DNA, obtida a partir de indivíduos fenotipicamente idênticos para uma região genômica de interesse. Construindo as amostras dessa forma, um pequeno segmento de DNA em particular pode ser estudado contra o "background" genético casualizado de 
locos não ligados, uma vez que todos os locos do genoma passam a se comportar como se estivessem em equilíbrio de ligação, exceto na região do genoma ligada ao loco selecionado (Tingey \& Tufo, 1993). A evidência de ligação entre um dado marcador molecular e o loco usado como referência para a construção das amostras é fornecida pela presença de marcas polimórficas entre os dois grupos. A ligação entre o marcador polimórfico e o loco alvo ainda deve ser confirmada através de uma análise de segregação com todos os individuos da população segregante. Através da co-segregação genética entre marcador e fenótipo, é possivel estimar o valor da freqüência de ligação entre o marcador e o gene que controla o caráter.

Qualquer loco marcador não ligado a essa região resulta em monomorfismos entre os "bulks", dada a freqüência de recombinação entre esses dois pontos ser suficiente para aleatorizar esses marcadores em relação a região alvo (Michelmore et al., 1991). Para marcadores ligados, quanto maior a distância de ligação entre marcador e loco alvo, maior a quantidade de recombinantes presentes em cada "bulk", até que nenhuma diferença possa ser detectada entre as amostras agrupadas devido a falta de desequilíbrio de ligação entre os mesmos.

A técnica de ASA tem superado vários problemas inerentes ao uso de LQIs e estoques genéticos para identificar marcadores ligados a genes particulares (Michelmore et al., 1991). Uma delas refere-se a reduzida probabilidade de regiões não ligadas ao gene alvo diferirem entre as amostras agrupadas (falsos positivos). Em contraste, apenas metade dos locos polimórficos entre LQIs podem efetivamente mapear a região selecionada, mesmo após cinco gerações de retrocruzamentos.

Um outro aspecto que favorece a análise dos segregantes agrupados, refere-se a sua capacidade de identificar polimorfismos apenas para marcadores localizados bem próximos ao loco alvo, a uma distância menor do que $30 \mathrm{cM}$ no caso de populações $F_{2}$ (Michelmore et al., 1991). Portanto, marcas muito distantes que segregam quase arbitrariamente em relação ao 
alvo não são detectadas, em contraste aos falsos positivos gerados em conseqüência da "linkage drag" produzida durante o processo de introgressão. Em outras palavras, isso significa que alguns dos locos identificados como polimórficos entre linhagens quase isogênicas podem não co-segregar em nenhuma outra população segregante destinada para mapeamento.

A análise via ASA ainda pode ser mais vantajosa quando for desejada apenas uma posição aproximada do gene de interesse no mapa. Nesse caso, os individuos segregantes para o caráter podem ser agrupados antes que seja feita a extração do DNA, requerendo, para tanto, apenas duas extrações. Além disso, não deve ser desprezada a facilidade e a rapidez com que os "bulks" podem ser construídos para regiões genômicas particulares, sem ter a necessidade de investir esforços adicionais para a geração de materiais genéticos específicos, tais como ocorre na geração de linhagens quase isogênicas (Giovannoni et al., 1991) e na manutenção de estoques citogenéticos (Weber \& Helentjaris, 1989).

ASA é especialmente útil para a identificação de marcadores em regiões ainda não cobertas do mapa genético (Ferreira \& Grattapaglia, 1995; Giovannoni et al., 1991; Reiter et al., 1992), que estejam pouco saturadas com marcadores (Michelmore et al., 1991). Para tanto, Giovannoni et al. (1991) propuseram o uso da estratégia de agrupamento monitorada por locos marcadores RFLPs previamente mapeados. A partir disso, foram identificados novos marcadores RAPDs para regiões do genoma que controlam o amadurecimento de frutos e a abscisão do pedicelo em tomate. Reiter et al. (1992) empregaram esse mesmo procedimento de mapeamento localizado ("local mapping") com amostras agrupadas definidas com base no polimorfismo do marcador disponível mais próximo da região de interesse. Novos marcadores polimórficos foram identificados entre as duas amostras e o ciclo foi repetido de forma a realizar um caminhamento em direção a região desejada do mapa. Foi dessa maneira que Reiter et al. (1992) mapearam um grande número de marcadores em um cromossomo específico de Arabidopsis. 
Muitas vezes, não existe interesse em mapear, mas apenas encontrar marcas ligadas a uma região alvo, visando simplesmente utilizá-las no processo de seleção indireta via marcadores moleculares. Assim, ASA tem sido usada com sucesso por vários grupos de pesquisa (Barua et al., 1993; Haley et al., 1994; Michelmore et al., 1991; Miklas et al., 1993) que trabalham com diferentes espécies vegetais. Michelmore et al. (1991), por exemplo, identificaram três marcadores RAPDs ligados ao loco (Dm5/8) de resistência ao mildio (Bremia lactucae) em alface (Lactuca sativa). Para tanto, foram necessárias 300 reações de PCR e dois "bulks" de DNA contrastantes, constituídos por indivíduos $F_{2}$ de genótipo conhecido para o gene de interesse. Barua et al. (1993) aplicaram ASA para identificar marcadores RAPDs ligados aos genes responsáveis pela resistência a Rhynchosporium em trigo. Assim, baseando-se na análise efetuada para duas amostras de DNA, foi possível identificar sete marcadores ligados ao gene de resistência localizado no braço longo do cromossomo 3. Os trabalhos de Haley et al. (1993) e Miklas et al. (1993), por outro lado, utilizaram uma população segregante derivada de retrocruzamento para um gene principal de resistência a ferrugem do feijoeiro. Esses autores utilizaram amostras de DNA agrupadas e identificaram marcadores RAPDs ligados a um gene de resistência a $U$. appendiculatus.

A análise de segregantes agrupados também pode ser extendida para caracteres geneticamente mais complexos e rapidamente identificar marcadores ligados a QTLs (locos de caracteres quantitativos). Em tomateiro, foram encontrados quatro marcadores RAPDs ligados a um QTL do cromossomo 6 que explicou $27,7 \%$ da variação fenotípica da resistência ao virus TYLCV (Chagué et al., 1997).

ASA também foi aplicada em associação a uma estratégia de mapeamento, onde apenas os indivíduos extremos da classe recessiva de uma população segregante foram usados para a localização de genes de interesse. Zhang et al. (1994) determinaram duas regiões cromossômicas contendo locos controladores da macho esterilidade genética sensível a fotoperíodo em arroz. 
Primeiramente, foi usada a estratégia de DNA agrupado a partir de plantas extremas da geração $F_{2}$ para identificar os segmentos cromossômicos portadores dos alelos da esterilidade/fertilidade e, posteriormente, os referidos genes foram localizados no mapa, analisando apenas os indivíduos $F_{2}$ estéreis correspondentes ao extremo da classe recessiva. Os idealizadores dessa estratégia sugerem que seu grande mérito está na utilidade em mapear genes cujos fenótipos não podem ser facilmente classificados dentro de classes discretas. Desde que os indivíduos que compõem a classe extrema sejam homozigotos para os alelos recessivos nos locos de interesse (Zhang et al., 1994) e que estes, por sua vez, contribuam significativamente para a manifestação do caráter (Wang \& Paterson, 1994), então a referida estratégia permite tanto a localização dos múltiplos locos que governam um dado caráter no mesmo grupo de indivíduos, bem como a localização de genes cuja expressão é afetada pelas condições ambientes. Além disso, a genotipagem da classe recessiva permite economizar um ciclo com avaliações pois, apesar do caráter analisado, muitas vezes, expressar-se de forma contínua e ser significativamente influenciado pelo ambiente, tanto a fenotipagem como a genotipagem são conduzidas na mesma geração sem a necessidade de testes de progênies adicionais.

Dentro desse contexto, o presente estudo pretende aplicar a estratégia de ASA para confirmar quais os segmentos cromossômicos ligados ao gene de resistência introgredido na linhagem elite $\mathrm{L} 30 \mathrm{HHH}$ e, concomitantemente, eliminar possiveis marcadores falsos positivos detectados com a análise via LQIs. Em segundo lugar, também pretende-se localizar 0 gene introgredido mediante a genotipagem e fenotipagem de cada indivíduo que compõe o extremo da classe recessiva de uma população $R C_{1} F_{1}$.

\subsection{Marcadores microssatélites}

\subsubsection{Características dos marcadores microssatélites}


Nas últimas duas décadas, qualquer variação na seqüência de DNA tem sido intensamente explorada como marcador genético para o mapeamento do genoma de várias espécies. Contudo, a tendência atual é considerar como características desejáveis para o marcador molecular ideal, a alta informatividade por loco e a facilidade e rapidez com que se obtêm tais informações.

Somente com o advento da reação de polimerização em cadeia (PCR, Mullis et al., 1986) foi possível desenvolver marcadores de DNA capazes de gerar informações com a facilidade e a rapidez desejáveis. Dentre os marcadores mais informativos baseados nas diferenças de comprimento das seqüências amplificadas pela PCR, estão aqueles que amplificam regiões contendo seqüências curtas de DNA repetitivas. Esses locos marcadores são conhecidos como "short tandem repeats-STRs" (Edwards et al., 1991), "short tandem DNA repeats", "microsatellites" (Litt \& Luty, 1989), "sequence-tagged microsatellite site-STMS" (Beckmann \& Soller, 1990), "simple sequence lenght polymorphism-SSLP" (Tautz, 1989), "tandem repeats of simple sequence", "repetitive DNA sequence" ou "simple sequence repeats-SSRs" (Litt \& Luty,1989; Weber \& May, 1989). Em plantas, esses marcadores já foram descritos para inúmeras espécies vegetais, incluindo arroz (Wu \& Tanksley, 1993), milho (Chin et al., 1996; Holm et al., 1994; Senior \& Heun, 1993), soja (Akkaya et al., 1992; Morgante \& Olivieri, 1993; Rongwen et al., 1995), brassicas (Lagercrantz et al., 1993), Arabidopsis (Bell \& Ecker, 1994), videira (Browers et al., 1996), árvores tropicais (Condit \& Hubbell, 1991), trigo e cevada (Saghai-Maroof et al., 1994), dentre outras.

Locos de microssatélites são constituídos por seqüências curtas de um a seis nucleotídeos comumente repetidos de 10 a 60 vezes em "tandem" (Gupta et al., 1996), ou centenas de vezes, tal como ocorre para o motivo ATT identificado em beterraba (Mörchen et al., 1996) ou, mais raramente, até milhares de vezes (Brown et al., 1996). Essas regiões são casualmente distribuídas pelo genoma dos eucariotos, numa quantidade correspondente a 
alguns milhares de vezes (Gupta et al., 1996). As seqüências de DNA que flanqueiam SSRs são conservadas, o que permite a seleção de "primers" específicos de 20 a 30 pares de bases e sua amplificação via PCR.

As aplicações dos marcadores microssatélites em genética vegetal tiveram início com o estudo das bibliotecas de DNA de cinco espécies de árvores tropicais e Zea mays, visando a detecção de clones contendo as seqüências de dinucleotídeos mais abundantes em mamíferos, ou seja, AC/GT e AG/CT. Condit \& Hubbell (1991) observaram que ambos motivos repetidos foram abundantes nos genomas de todas as seis espécies vegetais examinadas, tendo sido estimado um total de 5.000 a 300.000 sítios de $(A C)_{n}$ e $(A G)_{n}$, por genoma, com uma variação em comprimento de 16 a 22 pb (média de $18,4 \mathrm{pb})$ para os sítios contendo AC/GT.

Embora alguns estudos preliminares tenham indicado que os microssatélites mais abundantes e polimórficos no reino vegetal ainda podem variar de uma espécie vegetal a outra, em geral, os elementos repetidos mais comumente encontrados são $(A T / T A)_{n},(A / T)_{n}$ e $(A G / C T)_{n}$ (Morgante \& Olivieri, 1993; Moore et al., 1991; Wang et al., 1994), além dos motivos, (AAT/TTA)n, $(\text { AAC/TTG })_{n}, \quad(\text { AGC/GCT })_{n}, \quad(\text { AAG/TTC })_{n}, \quad(\text { AATT/TTAA })_{n}, \quad(\text { AAAT/TTTA })_{n}$ e $(A C / G T)_{n}$, em ordem decrescente (Wang et al., 1994). Os mesmos autores ainda ressaltam que dentre os tri e tetranucleotídeos mais abundantes, também destacam-se aqueles ricos em motivos A-T. Particularmente para um pequeno grupo formado por nove linhagens de milho, Chin et al. (1996) identificaram que as três classes mais abundantes de microssatélites foram (AG/CT) $n$ (47\% dos dinucleotídeos repetidos), (CCT/GGA $)_{n}$ e $(C C G / G G C)_{n}$, dentre 576 seqüências examinadas.

Quanto a distribuição dos microssatélites pelo genoma, algumas pesquisas realizadas em bancos de dados indicam que, dentro do reino vegetal, a freqüência de ocorrência e a própria forma de distribuição são amplamente variáveis. Em dicotiledôneas e monocotiledôneas (Wang et al., 1994), a freqüência média de ocorrência desses elementos repetitivos é da ordem de um 
loco a cada 21 mil e 65 mil pb, respectivamente. Para o milho (Zea mays L.), a freqüência média é de um loco a cada 50 mil pb (Chin et al., 1996 e Morgante \& Olivieri, 1993).

Quanto a localização, Wang et al. (1994) observaram que todos os elementos repetidos compostos por di e mononucleotídeos e por tetra e trinucleotídeos contendo A-T estavam localizados em regiões não codificadoras do DNA, enquanto que $57 \%$ dos trinucleotídeos contendo C-G foram encontrados dentro de regiões gênicas codificadoras. A grande maioria dos microssatélites de milho foram encontrados em bibliotecas de cDNAs, sítios de seqüências expressas ("ESTs") e genes conhecidos, incluindo introns e sequências flanqueadoras $5^{\prime}$ e 3 ', refletindo a ocorrência desses motivos repetidos em regiões situadas internas ou adjacentes aos genes de milho (Chin et al., 1996). De forma similar a Wang et al., (1994), Chin et al. (1996) também encontraram uma abundância de microssatélites triméricos dentro de regiões codificadoras. Os mesmos autores ainda ressaltaram que os demais motivos apresentaram uma distribuição muito diferente, uma vez que a maioria foi encontrada em regiões transcritas. Todas essas informações sugerem que é possivel gerar um mapa de cromossomos de plantas densamente saturado com marcadores microssatélites, usando uma mistura de motivos de seqüências repetidas compostos por di, tri e tetranucleotídeos.

\subsubsection{Variablidade dos locos microssatélites}

Para avaliar se as regiões contendo microssatélites são adequadas como marcadores genéticos em plantas, além de se estudar fatores tais como abundância e distribuição pelo genoma, também deve ser considerado o grau de polimorfismo presente por loco. Os microssatélites apresentam variabilidade como uma conseqüência das diferenças existentes no número de unidades de oligonucleotídeos contido no loco. Vários trabalhos têm demonstrado que o loco de microssatélite amplificado é o marcador que possui o maior número de 
informação de polimorfismo por loco, uma vez que possui expressão codominante e muitos alelos por loco (Chin et al. 1996), apesar do grau de polimorfismo variar de uma espécie para outra (Akkaya et al., 1992; Browers et al., 1996; Mörchen et al., 1996; Wu \& Tanksley, 1993). De qualquer forma, existe uma relação linear entre o número de alelos detectado para um dado loco e o comprimento do microssatélite: quanto maior o número de motivos repetidos de um microssatélite, maior o número de alelos detectados (Gupta et al., 1996). Chin et al. (1996) identificaram 200 locos de microssatélites potenciais dentre 576 seqüências examinadas, dos quais 69 apresentaram polimorfismos moderados caracterizados pela presença de dois a quatro alelos. Também em milho, Holm et al. (1994) testaram 28 seqüências de microssatélites: sete foram identificadas em uma biblioteca genômica e 21 a partir das entradas do GenBank de milho. Nesse estudo, um total de 19 sítios produziu uma média de três a cinco alelos por loco. Similarmente, Senior \& Heun (1993) encontraram quatro a cinco alelos por loco para seis sítios de microssatélites analisados em oito linhagens de milho.

A variabilidade dos microssatélites não é totalmente entendida, mas sugere-se que sua origem esteja associada a ocorrência de um "crossing-over" desigual ou de um mecanismo que ocorre durante a replicação do DNA, conhecido por "derrapamento, escorregamento ou pareamento desigual" ("slippage"), seguido de uma falha no sistema de reparo da enzima que restaura a seqüência original (Charlesworth et al., 1994; Levinson \& Gutman, 1987; Strand et al., 1993). A variação no comprimento do produto gerado pela PCR é função do número de unidades de SSRs e cada segmento amplificado de tamanho diferente representa um alelo especifico do mesmo loco. Portanto, o polimorfismo surge quando esses alelos diferem no número de vezes que um motivo é repetido no fragmento de amplificação. A Figura 1 ilustra a detecção de polimorfismo de comprimento de um dado loco de seqüências curtas repetidas, usando dois parentais e seu $F_{1}$. Nesse exemplo, o parental 1 é homozigoto para o alelo $(\mathrm{AT})_{n}$ e o parental 2 , para o alelo $(\mathrm{AT})_{n-8}$, cada qual 
Amplificação via PCR de um loco de micros-

satélite: motivos (AT)n repetidos em "tandem" de $\mathbf{P}_{1}, \mathbf{P}_{\mathbf{2}}$ and $\mathbf{F}_{1}$

Sítios conservados para "primers" de

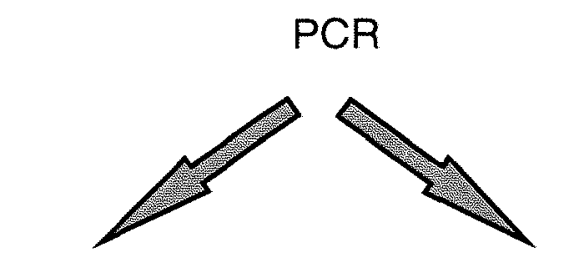

Eletroforese em gel de agarose $e$ visualização de produtos da PCR corados com brometo de etídio

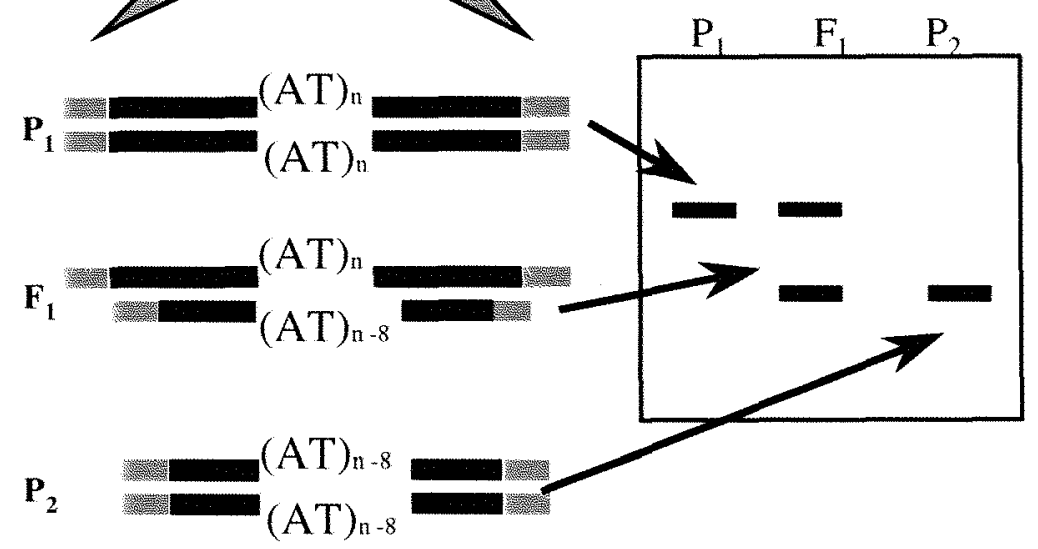

Figura 1 - Produção e visualização de polimorfismos de comprimento gerados via PCR com "primers" que amplificam regiões de microssatélites de dois parentais hipotéticos $\left(P_{1}\right.$ e $\left.P_{2}\right)$ e do híbrido $F_{1}$ correspondente $\left(P_{1} \times P_{2}\right)$. A letra (n) representa o número de motivos repetidos do loco amplificado. 
produzindo uma única banda, gerada como produto de amplificação da PCR. O híbrido $F_{1}$, produzido a partir do cruzamento entre os dois parentais, é heterozigoto e, portanto, produz duas bandas que correspondem a amplificação de ambos os alelos.

\subsubsection{Peculiaridades da amplificação dos locos SSRs}

Parece existir um consenso quanto a grande utilidade dos motivos $(A T)_{n}$ e $(A G)_{n}$ para a análise genômica em plantas, pois além de serem abundantes e facilmente isolados, também apresentam uma alta repetibilidade, não detectada nos produtos de amplificação dos locos RAPDs. Entretanto, apesar das seqüências repetidas compostas por tri e tetranucleotídeos serem geralmente menos abundantes, pode-se comprovar que as mesmas ainda são mais úteis do que qualquer elemento formado por dinucleotídeos, dado a ausência de bandas múltiplas (bandas "stutter") produzidas pela Taq polimerase (Brown et al.,1996). Esse padrão de produtos da PCR (bandas "stutter") torna bastante difícil a determinação precisa do tamanho dos alelos do loco de SSRs, uma vez que podem ser vistas múltiplas bandas para cada alelo. Segundo relatos de Weber \& May (1989) e Litt \& Lutty (1989), as bandas mais fortes de cada linha da eletroforese correspondem ao alelo; as bandas mais luminosas, situadas acima da banda forte, provavelmente resultam do movimento lento das fitas contendo dinucleotídeos, enquanto as bandas menores são produzidas como conseqüência de falhas ("slippage") da polimerase sobre a fita molde durante a PCR.

Outro artefato da amplificação pode resultar da incidência de "primers" diméricos, cuja formação ocorre quando um "primer" é extendido pela polimerase usando o outro "primer" ou ele próprio como molde (Newton \& Graham, 1997). Esse curto produto pode ser um problema naqueles casos onde não ocorreu a amplificação do produto desejado, pois o mesmo pode ser confundido com o alelo pretendido na amplificação do loco de microssatélite. 
Contudo, esse é um problema intrínseco à técnica, quando os pares de "primers" são construídos de tal forma que seus terminais 3' tenham complementaridade (Newton \& Graham, 1997).

A própria dificuldade ou mesmo a falta de amplificação pode ser outro problema bastante comum e específico de alguns pares de "primers" que flanqueiam locos de "SSRs". Tal fato pode ser o resultado da concentração inadequada de algum componente da reação ou das condições impróprias usadas durante a PCR, principalmente em relação a razão entre "primer" : DNA molde e a temperatura de anelamento a exemplo do que ocorre com marcadores RAPDs (Ellsworth et al., 1993). A qualidade dos produtos de amplificação e a própria ocorrência da reação de amplificação podem variar significativamente em função das condições de reação da PCR para cada loco SSRs em particular. A determinação específica da concentração do par de "primers" e da temperatura de anelamento usada nos ciclos de amplificação são fatores decisivos para a amplificação de locos de microssatélites.

\subsubsection{Vantagens dos marcadores microssatélites}

Dentre algumas vantagens dos marcadores microssatélites, primeiramente, pode-se destacar 0 fato de serem muito freqüentes $e$ regularmente distribuídos pelos genomas eucariotos (Chin et al. 1996; Mörchen et al., 1996). Por essas duas razões, microssatélites são considerados bastante adequados como marcadores genéticos. Adicionalmente, requerem pouca quantidade de DNA (dezenas de nanogramas) de qualquer tecido da planta para a amplificação, são loco-específicos e somaticamente estáveis, além de possuírem locos que freqüentemente são conservados entre espécies (Kresovich et al., 1995) e, algumas vezes, até entre gêneros relacionados pertencentes a uma mesma família, como observado em alguns gêneros da família Brassicacea e Poaceae (Brown et al., 1996). Dadas as características dos microssatélites, é possível uma fácil transferência desses marcadores entre 
mapas genéticos construídos a partir de diferentes cruzamentos, em contraste aos marcadores dominantes que podem freqüentemente requerer a geração de um novo mapa para cada cruzamento (Chin et al., 1996). Além disso, são mais convenientes do que os clássicos marcadores RFLPs, uma vez que o processo para seu isolamento e definição já tem sido superado (Mörchen et al., 1996).

Marcadores microssatélites ainda têm atraído o interesse dos estudiosos em genética de populações, devido ao freqüente polimorfismo também detectado dentro de populações. Em termos comparativos, a heterozigosidade dos marcadores microssatélites é sete a dez vezes mais alta do que os marcadores RFLPs (Wu \& Tanksley, 1993). Isso significa que a probabilidade de encontrar um marcador microssatélite polimórfico numa dada região do genoma, para um cruzamento envolvendo parentais dentro de uma subespécie ou entre duas subespécies, deverá ser maior do que a de encontrar um marcador RFLP. Pela citada variação e por serem provavelmente seletivamente neutros, tais marcadores têm oferecido um grande potencial para estudos de parentesco, de fluxo gênico dentro e entre populações, bem como de extensão e manutenção da diversidade genética (Condit \& Hubbell, 1990). Os microssatélites já são especialmente importantes para aquelas espécies portadoras de baixos níveis de diversidade genética, tal como a soja (Akkaya et al., 1992; Morgante \& Olivieri, 1993, Rongwen et al., 1995), onde a construção de mapas genéticos baseados em RFLP ou RAPD é muito difícil. Morgante \& Olivieri (1993), por exemplo, mostraram a maior informatividade dos locos SSRs em relação a um conjunto comparável de locos RFLPs, dada a estimativa de um número de alelos equivalente a 4,25 por loco de SSRs vs. 2,15 por loco de RFLPs, em 19 linhagens de soja.

Uma vez desenvolvidos os "primers" que amplificam os locos de microssatélites, pode-se evidenciar a facilidade e a rapidez na geração de marcas que dispensam o uso de radioatividade e que envolve uma tecnologia de baixo custo, baseada essencialmente na amplificação via PCR e eletroforese. Além disso, as dificuldades existentes com a transferência física 
de sondas entre laboratórios pode ser excluída, pois a informação gerada pode ser prontamente transferivel, bastando apenas ser comunicada a seqüência dos pares de "primers".

A partir do momento que essa tecnologia estiver associada a um processo de extração e de PCR automatizados, será possível analisar elevadas quantidades de amostras a um baixo custo unitário, em operações de grande escala, tal como normalmente ocorre dentro dos programas de melhoramento orientados por marcadores e durante os processos de análise do perfil dos recursos genéticos disponíveis. 


\section{MATERIAL E MÉTODOS}

\subsection{Material vegetal}

Foram utilizadas duas linhagens quase isogênicas (LQIs) de milho contrastantes pela presença/ausência de um alelo dominante $H t$ que confere resistência a Exserohilum turcicum. A linhagem codificada como $\mathrm{L} 30 \mathrm{HtH}$ foi gerada a partir de um programa de retrocruzamento envolvendo a variedade resistente $\mathrm{L} 10 \mathrm{HtH}$ como parental doador do gene $H t$ e a linhagem suscetivel L30htht como parental recorrente. A cada ciclo de retrocruzamento, plantas $\mathrm{RC}_{n} \mathrm{~F}_{1}$ foram inoculadas com um isolado de $E$. turcicum coletado em CravinhosSP, cujo espectro de virulência é desconhecido. Plantas resistentes heterozigotas $(H$ tht $)$ foram selecionadas a cada ciclo e retrocruzadas com o parental recorrente suscetível (L30htht) durante seis gerações. Ao final, uma população segregante $R_{6} F_{2}$ foi gerada pela autofecundação de todas as plantas resistentes da geração $\mathrm{RC}_{6} \mathrm{~F}_{1}$ (Figura 2). Plantas $\mathrm{RC}_{6} \mathrm{~F}_{2}$ foram então submetidas a um cruzamento-teste com uma linhagem altamente suscetivel, visando a identificação e seleção de plantas resistentes homozigotas. A condição heterozigota ou homozigota das plantas $R_{6} F_{2}$ resistentes foi confirmada pela presença ou ausência de segregantes dentro das progênies resultantes do cruzamento-teste na proporção $3: 1$ de indivíduos resistentes: suscetiveis. Sementes remanescentes dos indivíduos $\mathrm{RC}_{6} \mathrm{~F}_{2}$ homozigotos para alelos de resistência foram utilizadas para mais um ciclo de autofecundação com a finalidade de gerar a linhagem $R_{6} \mathrm{~F}_{3}\left(\mathrm{RC}_{6} \mathrm{~S}_{1}\right)$, designada de linhagem "L30HtHt convertida".

Adicionalmente, foi utilizada uma população segregante $R C_{1} F_{1}$ 
L10HtHt (resistente) $\times$ L30htht (suscetivel)

$$
\begin{gathered}
\downarrow \\
F_{1} \text { (Htht) } \times \text { L30htht } \\
\downarrow
\end{gathered}
$$

Seleção das plantas resistentes $\rightarrow R_{1} F_{1}(H$ tht $) \times$ L3Ohtht Geração de $R_{2}$

$$
\begin{array}{llc}
\text { Resistentes } & \rightarrow & \mathrm{RC}_{6} \mathrm{~F}_{1} \text { (Htht) } \\
\text { Autofecundação } \rightarrow & \downarrow \\
\text { Cruzamento-teste } \rightarrow \mathrm{RC}_{6} \mathrm{~F}_{2} & \times & \text { Suscetível } \\
& \downarrow
\end{array}
$$

Seleção de plantas homozigotas resistentes $\rightarrow R_{6} F_{2}(\mathrm{HtHt})$

$$
\begin{aligned}
\text { Autofecundação } \rightarrow & \downarrow \\
\text { Linhagem Convertida L30 HtHt } \rightarrow & \mathrm{RC}_{6} \mathrm{~F}_{3}
\end{aligned}
$$

Figura 2 - Esquema de retrocruzamentos utilizado para a obtenção da linhagem isogênica convertida $(\mathrm{L} 30 \mathrm{HtHt})$. 
[(L30HtHt $\times$ L40htht) $\times$ L40htht], gerada do cruzamento-teste entre a linhagem resistente convertida L30HtHt e a linhagem suscetivel L40htht, a partir da qual obtiveram-se os indivíduos segregantes necessários para a análise dos extremos segregantes agrupados (ASA) e dos individuos extremos da classe recessiva com marcadores moleculares microssatélites.

Todo material vegetal foi desenvolvido e gentilmente cedido pela empresa Sementes Agroceres SIA.

\subsection{Extração de DNA vegetal}

O procedimento de extração de DNA vegetal foi baseado em protocolo descrito por Hoisington et al. (1994). Aproximadamente $5 \mathrm{~g}$ de folhas congeladas a $-80^{\circ} \mathrm{C}$, obtidas a partir de plantas contendo no mínimo 10 folhas, foram transformadas em um fino pó pela adição de gelo seco ao material foliar e moagem em moedor de café elétrico. Cada amostra foi colocada em tubos de polipropileno de $50 \mathrm{ml}$ e ressuspendida em $10 \mathrm{ml}$ de $1 \mathrm{x}$ tampão de extração CTAB (700 mM NaCl; 50 mM EDTA, PH 8,0; $100 \mathrm{mM}$ Tris - $\mathrm{HCl}, \mathrm{pH} \mathrm{7,5;1 \%}$ $\mathrm{p} / \mathrm{v}$ de hexadecil-trimetilamônio de bromida e $140 \mathrm{mM}$ de $\beta$-mercapto-etanol), previamente aquecido a $65^{\circ} \mathrm{C}$. A seguir, as amostras foram incubadas em banho de água aquecida a $65^{\circ} \mathrm{C}$ por 60 minutos e invertidas gentilmente a cada 10 minutos.

Após a remoção dos tubos do banho quente, as amostras foram resfriadas por 4 a 5 minutos e extraídas duas vezes com $10 \mathrm{ml}$ de clorofórmio/álcool isoamílico (CIA 24:1). Em cada extração, os tubos foram gentilmente invertidos por 5 minutos, antes de centrifugá-los por 10 minutos a 3400 rpm em rotor tipo "swinging buckets". Ao final de cada extração, a camada aquosa sobrenadante foi transferida para novos tubos de $50 \mathrm{ml}$. A precipitação do DNA foi efetuada pela adição de igual volume de etanol absoluto ( $1 \times$ volume de sobrenadante) resfriado a $-20{ }^{\circ} \mathrm{C}$ e pela gentil inversão dos tubos durante 5 minutos, seguida de centrifugação a $3400 \mathrm{rpm}$ por 10 minutos. A seguir, o 
precipitado foi lavado durante 20 minutos com etanol $75 \%$ e $90 \%$ a temperatura ambiente e, por último, com etanol absoluto resfriado a $-20^{\circ} \mathrm{C}$. O DNA foi resuspendido em $500 \mu \mathrm{l}$ de TE (10 mM Tris- $\mathrm{HCl}$, PH 8,0 e $1 \mathrm{mM}$ EDTA, PH 8,0) e incubado até seis horas em RNAse $(10 \mathrm{mg} / \mathrm{ml})$, a uma temperatura de $37^{\circ} \mathrm{C}$.

Numa segunda etapa, os DNAs diluídos em TE foram transferidos para tubos "eppendorfs" de $1500 \mu \mathrm{l}$ e submetidos a mais duas extrações: a primeira efetuada com $500 \mu$ de fenol-Tris $\mathrm{HCl}$ equilibrado para $\mathrm{PH} \geq 7,8$ e a segunda em igual volume com clorofórmio/álcool isoamilico (24:1). Para ambas as extrações, após a inversão dos tubos por 5 minutos, os mesmos foram centrifugados por 10 minutos a $12.000 \mathrm{rpm}$ em centrífuga de mesa, antes de ser efetuada a transferência da camada sobrenadante para novos tubos eppendorffs. O DNA foi reprecipitado com a adição de $125 \mu \mathrm{l}$ de $\mathrm{NaCl} 5 \mathrm{M}$ e 0,5 $\mathrm{ml}$ de etanol absoluto seguida de centrifugação por 10 minutos a $12000 \mathrm{rpm}$. 0 precipitado foi lavado com solução de lavagem I (etanol 76\% e 0,2 M de acetato de potássio) durante 20 minutos e rinsado com solução de lavagem II (etanol $76 \%$ e $10 \mathrm{mM}$ de acetato de amônio). O DNA foi re-suspendido em $500 \mu \mathrm{l} \mathrm{TE} \mathrm{e}$ armazenado a $4^{\circ} \mathrm{C}$ até o momento do uso.

\subsection{Otimização de protocolos de amplificação de locos de microssatélites}

Reações de polimerização em cadeia (PCR) foram efetuadas em um termociclador MJ Research model PTC-100 (MJ Research) a partir de modificações efetuadas sobre o protocolo descrito por Senior et al. (1996). As reações foram constituídas de $10 \mathrm{ng}$ de DNA molde; $0,1 \mathrm{mM}$ de cada dNTPs (desoxinucleosídeotrifosfato) ; $1 \mathrm{U}$ de Taq polimerase (Promega); $1 \times$ tampão de reação $\left(50,0 \mathrm{mM} \mathrm{KCl}, 1,5 \mathrm{mM} \mathrm{MgCl}_{2}, 10,0 \mathrm{mM}\right.$ Tris- $\mathrm{HCl}, \mathrm{PH} 9,0$ a $25^{\circ} \mathrm{C}$ e $0,1 \%$ Triton X -100); 0,5 $\mathrm{mM}$ adicionais de $\mathrm{MgCl}_{2}$ e concentrações variando de 0,165 $\mu \mathrm{M}$ a 1,0 $\mu \mathrm{M}$ de cada par de "primers" (Maize MapPairs ${ }^{\mathrm{TM}}$; Research Genetics) em um volume final de $30 \mu \mathrm{l}$. Antes de dar início a reação de polimerização em 
cadeia, adicionou-se $50 \mu$ de óleo mineral sobre cada reação.

Os protocolos de amplificação foram otimizados para cada loco e variaram em função do número de ciclos de amplificação e da temperatura de anelamento $\left(T_{A}\right)$ estimada para cada par de "primers", segundo a fórmula $T_{A}=$ $\left[2{ }^{\circ} \mathrm{C} \times\right.$ (Adenina + Timina $)+4{ }^{\circ} \mathrm{C} \times($ Citosina+Guanina $\left.)-5^{\circ} \mathrm{C}\right]$, descrita por Newton \& Graham (1997). A $T_{A}$ foi estimada com base na seqüência de bases dos "primers reverse/forward" disponiveis em http:llwww.agron.missouri.edu. Essas estimativas da $T_{A}$ serviram como ponto de partida para experimentos de otimização dos programas da PCR naqueles casos onde as amplificações efetuadas pelo programa básico (abaixo referido como programa 1) não foram bem sucedidas.

Inicialmente, todos os programas de termociclagem incluiram uma desnaturação inicial de três minutos a $94{ }^{\circ} \mathrm{C}$, seguido por ciclos de desnaturação de um minuto a $94^{\circ} \mathrm{C}$, anelamento de um minuto a uma dada temperatura que variou em função do programa de amplificação utilizado e extensão de dois minutos a $72{ }^{\circ} \mathrm{C}$. Para os programas 1 e 4 , as temperaturas de anelamento dos ciclos iniciais de amplificação decresceram $10{ }^{\circ} \mathrm{C}$ a uma taxa de $-1^{\circ} \mathrm{C}$ a cada 2 ciclos, enquanto que para os programas $2,3,5,6,7$ e 8 , esses decréscimos foram de apenas $5^{\circ} \mathrm{C}$ a uma taxa de redução igual a anterior (etapa 1, Tabela 1).

As temperaturas de anelamento iniciais da etapa 1 da PCR foram estabelecidas considerando que estas deveriam estar acima ou próximas da maior $T_{A}$ do par de "primers forward/reverse" e o valor final, próximo ou abaixo da menor $T_{A}$ desse mesmo par. Contudo, como a temperatura de anelamento ideal para alguns locos marcadores pode estar de 3 a $12{ }^{\circ} \mathrm{C}$ acima da $T_{A}$ estimada (Newton \& Grahm, 1987), então adotou-se como um segundo e último critério o estabelecimento de temperaturas iniciais $\left(T_{A}\right)$ superiores a ambos os componentes do par de "primers". A partir desse modelo de amplificação foram elaborados programas com reduções de temperatura de $65^{\circ} \mathrm{C}$ a $55^{\circ} \mathrm{C}$ (programa básico ou programa 1, baseado em Senior et al., 


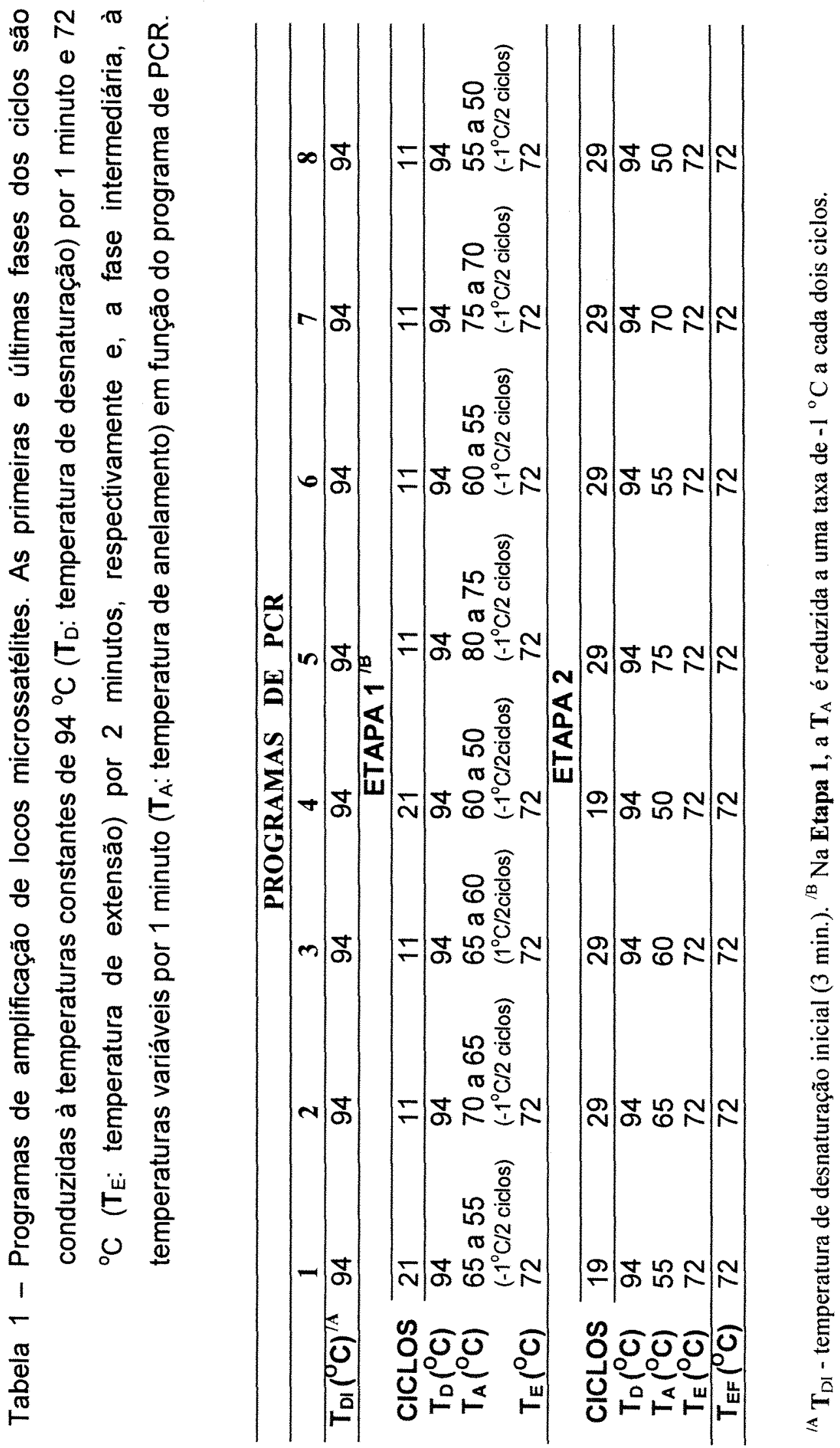


1996), de $70{ }^{\circ} \mathrm{C}$ a $65^{\circ} \mathrm{C}$ (programa 2), de $65^{\circ} \mathrm{C}$ a $60^{\circ} \mathrm{C}$ (programa 3), de $60^{\circ} \mathrm{C}$ a $50^{\circ} \mathrm{C}$ (programa 4 ), de $80^{\circ} \mathrm{C}$ a $75^{\circ} \mathrm{C}$ (programa 5 ), de $60{ }^{\circ} \mathrm{C}$ a $55^{\circ} \mathrm{C}$ (programa 6), de $75^{\circ} \mathrm{C}$ a $70{ }^{\circ} \mathrm{C}$ (programa 7 ) e de $55^{\circ} \mathrm{C}$ a $50^{\circ} \mathrm{C}$ (programa 8 ). Após ter sido atingida a temperatura final de anelamento da etapa 1 , cada programa foi submetido a ciclos adicionais de amplificação (etapa 2, Tabela 1). Os programas 1 e 4 tiveram um acréscimo de 19 ciclos de PCR e os programas $2,3,5,6,7$ e 8 de 29 ciclos. Todos os programas foram finalizados com uma extensão de 5 minutos a $72^{\circ} \mathrm{C}$.

Para aqueles casos onde os fragmentos de microssatélites não ficaram bem definidos quando amplificados a uma concentração de "primer" (forward/reverse) de 0,165 $\mu \mathrm{M}$, procurou-se definir a combinação mais apropriada entre a temperatura de anelamento usada no programa de amplificação e a concentração do citado componente. As concentrações de "primers" utilizadas no presente trabalho foram de $0,165 \mu \mathrm{M}, 0,33 \mu \mathrm{M}, 0,5 \mu \mathrm{M}$, $0,67 \mu \mathrm{M}$ e $1,00 \mu \mathrm{M}$.

Fragmentos de microssatélites foram resolvidos em gel de agarose (Boehringer Mannheim $\mathrm{GmbH}$ ) a concentração de $3 \%$, preparado com tampão TBE 1x (0,09 M Tris-borato e 2,0 mM EDTA) e corado com brometo de etídio a uma concentração final de $0,5 \mu \mathrm{g} / \mathrm{ml}$. Foi utilizado $20 \mu \mathrm{l}$ de cada reação acrescida de $3 \mu \mathrm{l}$ de tampão de carregamento $(0,25 \%$ de azul de bromofenol, $0,25 \%$ de xylene cyanol e $30 \%$ de glicerol em água). Como padrão de pesos moleculares foi utilizado $0,5 \mu \mathrm{g}$ de "DNA Ladder" $50 \mathrm{pb}$ da GibcoBRL ou $2 \mu \mathrm{g}$ de "DNA Ladder" $50 \mathrm{pb}$ da Pharmacia Biotech, juntamente com $2 \mu \mathrm{l}$ de tampão de carregamento $(0,25 \%$ de azul de bromofenol, $0,25 \%$ de xylene cyanol e $30 \%$ de glicerol em água).

A eletroforese foi conduzida em tampão TBE $1 x$ a uma voltagem constante de $80 \mathrm{~V}$, durante um período variável de 3 a 6 horas dependendo da menor ou maior necessidade de separação dos fragmentos. A visualização do gel foi efetuada sobre um transiluminador UV e registrada através de câmara fotográfica Polaroid, carregada com filme preto e branco tipo pancromático Fuji 
Instant (FP-100B/Super), com abertura de 5,6 e exposição de dez segundos. As fotografias resultantes foram editadas pelo software ImageMaster VDS (Pharmacia Biotech).

\subsection{Análise genética de linhagens quase isogênicas (LQIs)}

Para a análise genética das linhagens quase isogênicas, foram necessárias extrações individuais do DNA da variedade doadora (PD), das linhagens convertida (LQI) e recorrente (PR), bem como do híbrido resultante do cruzamento entre convertida $x$ recorrente. O DNA extraído foi submetido a reações de polimerização em cadeia (PCR) otimizadas para 125 pares de "primers", conforme resultados do estudo de otimização de amplificação dos mesmos. A evidência de ligação foi obtida para aqueles casos onde o loco marcador apresentou um contraste alélico entre parental recorrente e parental doador (L30htht/L10HtHt) e uma igualdade alélica entre parental doador e linhagem convertida (L10HtHt/L30HtHt). A eficiência do retrocruzamento foi avaliada com base na percentagem de alelos marcadores da linhagem recorrente presentes na linhagem convertida.

As proporções médias esperadas do genoma do parental doador $(\mathrm{L} 10 \mathrm{HtH} t)$ que fica retida no genoma $\left(\mathrm{u}_{\mathrm{T}}\right)$ da linhagem convertida $\mathrm{L} 30 \mathrm{HtH}$ de $\mathrm{RC}_{6} \mathrm{~F}_{3}\left(\mathrm{RC}_{6} \mathrm{~S}_{1}\right)$, no cromossomo marcador que recebeu o gene introgredido ( $\left.U_{M}\right)$ ou em qualquer outro cromossomo individual não marcador ( $u_{N}$ ) foram estimadas mediante fórmulas aplicadas por Muehlbauer et al. (1988) dadas por:

$$
\begin{gathered}
u_{T}=\left[(L)\left(u_{M}\right)+(n-1)(L)\left(u_{N}\right)\right] /(n L) ; \\
u_{M}=(2 / L)\left[(1 / t)\left(1-e^{-t / 2}\right)\right] ; \\
u_{N}=(1 / 2)^{t}
\end{gathered}
$$

(Hanson, 1959; Stam \& Zeven, 1981); com suas respectivas variâncias

$$
\begin{gathered}
V_{T}=\left[(L)\left(V_{M}\right)+(n-1)(L)\left(V_{N}\right)\right] /[(n L)] ; \\
V_{M}=\left(2 / L^{2}\right)\left\{\left[\left(1 / t^{2}\right)\left(2-(t L+2) e^{-t L / 2}\right)\right]-\left[(1 / t)\left(1-e^{-t L / 2}\right)\right]^{2}\right\} ; \\
V_{N}=\left[(1 / 2)^{t}(2 / L)(1 / t)\left(1-e^{-t / 2}\right)\right]-\left[(1 / 2)^{t}\right]^{2}
\end{gathered}
$$


(Stam \& Zeven, 1981); onde n é o número de cromossomos (em milho, $\mathrm{n}=10$ ) de comprimento $L=1,61 \mathrm{M}$ (distância média do mapa genético total: $n L=16,10$ M) (Davis et al.,1996); $t$ representa o número de gerações onde ocorreram eventos meióticos envolvendo um marcador heterozigoto introgredido e b é o número de ciclos de retrocruzamentos.

Para tanto, assumiu-se que a introgressão foi efetuada na ausência de seleção fenotípica para outras características do parental recorrente e que o gene introgredido foi inserido no centro do cromossomo. Considerando que a linhagem convertida L30HtHt é derivada de uma progênie autofecundada de um indivíduo heterozigoto para o gene introgredido $\left(R C_{6} F_{3}=R C_{6} S_{1}\right)$, então $t=b+1$ $=7$, pois $b=6$.

Mediante essas estimativas, foi possivel inferir a proporção esperada de locos marcadores derivados do parental doador que fica retida no genoma total da linhagem $L 30 H t H t$ de $R_{6} S_{1}-\left(100 \times u_{T}\right)$ - e, dessa fração, qual a proporção esperada de locos marcadores localizados no bloco de ligação que circunda a região do gene introgredido - $\left[100 \times\left(u_{M} \times L\right) /\left(u_{T} \times n L\right)\right]$ (Muehlbauer et al. 1988) - e a proporção esperada de locos marcadores localizados nos demais cromossomos $\left\{100 \times\left[U_{N} \times(n-1) \times L\right] /\left(U_{T} \times n L\right)\right\}$ (Muehlbauer et al. 1988).

A probabilidade de erros com a estratégia de análise de linhagens quase isogênicas foi avaliada a posteriori, considerando tanto aqueles casos envolvendo os marcadores falsos negativos (erro tipo II), bem como os falsos positivos (erro tipo I). Em termos matemáticos, a proporção de falsos negativos foi estimada mediante $P^{-}=\left\{100 \times\left[(L)\left(1-u_{M}\right)\right] /\left[(n L)\left(1-u_{T}\right)\right]\right\}$ e de falsos positivos através de $P^{+}=\left\{100 \times\left[(n-1)(L)\left(u_{N}\right)\right] /\left[(n L)\left(u_{T}\right)\right]\right\}$, onde $u_{M}, u_{N}, n$ e $L$ têm o mesmo significado anteriormente descrito. Nesse caso, a probabilidade de falsos negativos é função da proporção esperada do genoma do parental recorrente recuperada pelo cromossomo portador do gene $\mathrm{Ht}$ em relação a proporção esperada recuperada por todos os cromossomos. Correspondem aos locos marcadores informativos que são monomórficos entre parental recorrente e linhagem convertida, apesar de estarem ligados a região alvo. Já a 
probabilidade de falsos positivos é função da proporção esperada do genoma do parental doador retida nos cromossomos não portadores do gene $\mathrm{Ht}$ em relação a proporção esperada retida em todos os cromossomos. Correspondem aos locos marcadores informativos que revelam monomorfismos entre parental doador e linhagem convertida, apesar de não estarem ligados a região alvo.

\subsection{Seleção de isolados que discriminam a reação de resistência conferida pelo gene $\mathrm{Ht}$}

\subsubsection{Cultura monospórica}

Culturas monospóricas foram obtidas mediante inoculação em plantas suscetiveis e re-isolamento em meio ágar-água. Para tanto, pequenos pedaços de folhas infectadas, contendo uma parte de tecido verde e outra de tecido necrosado, foram rinsados numa solução de álcool a $70 \%$. A seguir, foram transferidos para uma solução de hipoclorito de sódio a $1 \%$ por dois minutos e, por último, rinsados em água destilada autoclavada. A partir disso, os pedaços de folhas foram deixados cerca de cinco dias em meio ágar-água.

Após esse periodo, as extremidades das hifas de cada isolado foram transferidas para meios de cultura à base de lactose-caseína-hidrolizadaágar (LCH) (Tuite, 1969) e incubados no escuro por um período de duas semanas a $24{ }^{\circ} \mathrm{C}$ (Robbins \& Warren, 1993). Culturas monospóricas foram obtidas destes isolados e mantidas por duas semanas em meio BDA, com 12 horas de luz fluorescente $\left(320 \mathrm{uE} \mathrm{s}^{-1} \cdot \mathrm{m}^{-2}\right.$ ) a uma temperatura de $20^{\circ} \mathrm{C}$ (Lipps et al., 1997).

\subsubsection{Preparo de inóculo, inoculação e seleção de isolados}

Nessa etapa, pretendeu-se identificar um isolado de Exserohilum turcicum capaz de discriminar a presença do alelo de resistência presente na 
linhagem $\mathrm{L} 30 \mathrm{HtH}$. Para tanto, $\mathrm{O}$ isolado ideal deveria vencer todos os outros genes de resistência qualitativa dominantes ou recessivos presentes em L30 que fossem diferentes de $H t$, além de possibilitar a discriminação de $H t$ em uma população segregante $\mathrm{RC}_{1} \mathrm{~F}_{1}$ obtida do cruzamento [( $\left.\mathrm{L} 30 H t H t \times L^{2} 40 h t h t\right) \mathrm{F}_{1} \times$ L40htht].

A produção de inóculo foi efetuada em meio estéril contendo sementes de sorgo embebidas em água na proporção 1,5 semente : 1 água (v/v), a partir dos isolados monospóricos multiplicados em BDA (seção 3.5.1). Após um período de incubação de três semanas a uma temperatura de $24{ }^{\circ} \mathrm{C}$ em regime de escuro contínuo, o inóculo foi mantido a temperatura ambiente até a época de inoculação.

As linhagens isogênicas L30HtHt (convertida), L30htht (recorrente) e L30Htht, a linhagem L40htht utilizada para a geração da população [( L30HtHt $\times$ L40htht) x L40htht] e os hibridos (L30HtHt x L40htht) e (L30htht $\times$ L40htht) foram semeados a campo, em unidades constituídas por $1 \mathrm{~m}^{2}$ de área útil, sem repetições e distribuídas em fileiras simples espaçadas a $1 \mathrm{~m}$ entre si, contendo cinco plantas distanciadas a $0,20 \mathrm{~cm}$.

Os referidos genótipos foram inoculados com cinco isolados de $E$. turcicum, dos quais um era portador de genes de virulência previamente conhecidos e quatro foram identificados nesse trabalho, conforme 0 procedimento descrito em 3.6. $O$ isolado 18 foi coletado em Santa Cruz das Palmeiras-SP pela Sementes Agroceres S/A e identificados por Gianasi (1996) como pertencente a raça $12 \mathrm{~N}$, conforme nomenclatura proposta por Leonard et al. (1989); os isolados 47,48 e 53 , sem identificação quanto a raça, foram coletados pela Sementes Agroceres S/A, em Cravinhos-SP e Chapadão do SulMS e pela Zeneca Sementes, em Cravinhos-SP, respectivamente. Finalmente, o isolado 49, também de identidade desconhecida, foi coletado no Estado do Paraná.

A inoculação de cada isolado foi efetuada no estádio de quatro a seis folhas, sobre plântulas com aproximadamente 3 semanas de idade, 
introduzindo cerca de 20 sementes de sorgo dentro do cartucho (Carson, 1995) de cada planta. Cerca de 20 dias após a inoculação, foram conduzidas as avaliações quanto ao tipo de lesão, segundo escala de notas descrita em Esteves (1989), a saber:

-Nota 1 (tipo de reação $R_{1}$ ): ausência de sintomas;

-Nota 2 (tipo de reação $R_{2}$ ): pontos cloróticos ou pequenas lesões clorótico-necróticas de formato circular;

-Nota 3 (tipo de reação $R_{3}$ ): lesões clorótico-necróticas em fase inicial de desenvolvimento ou presença de lesões clorótico-necróticas estreitas, dispostas ao longo das nervuras e freqüentemente extendendo-se à nervura mais próxima;

-Nota 4 (tipo de reação $\mathrm{R}_{4}$ ): presença de lesões clorótico-necróticas grandes, podendo haver coalescência entre lesões;

-Nota 5 (tipo de reação $S_{5}$ ): presença de lesões necróticas delimitadas, sem halo clorótico e com bordos mais escuros na periferia das lesões;

-Nota 6 (tipo de lesão $S_{6}$ ): presença de lesões necróticas sem delimitação, com murcha e seca na extremidades das folhas.

Visando confirmar se em condições controladas de umidade e temperatura os isolados ainda seriam capazes de continuar discriminando a presença do gene $H t$ na população segregante $R C_{1} F_{1}$, repetiu-se, em casa de vegetação, a inoculação individual dos híbridos isogênicos ( $\mathrm{L} 30 \mathrm{HtH}$ t $\times$ L40htht) e (L30htht $\times$ L40htht), juntamente com o conjunto de linhagens diferenciadoras de milho descrito no item 3.6. O procedimento adotado para o preparo de inóculo, inoculação e avaliação foi similar ao descrito anteriormente.

\subsection{Identificação de raças e do espectro de resistência conferido pelo gene $\mathrm{Ht}$ introgredido em L30HtHt}

Com a finalidade de identificar o gene introgredido em $\mathrm{L} 30 \mathrm{HtHt}$, 
primeiramente foi necessário estudar o espectro de virulência dos isolados testados em 3.5.2. Para tanto, em condições de casa de vegetação, os cinco isolados cultivados em sorgo foram inoculados individualmente, sobre um conjunto de linhagens isogênicas diferenciadoras de milho $(\mathrm{Pa}, \mathrm{PaHt}, \mathrm{PaHt}$, $\mathrm{PaHt}_{3}$ e $\mathrm{PaHtN}$ ), gentilmente remetidas por Dr. M. L. Carson (Universidade do Estado da Carolina do Norte - EUA) e sobre os hibridos (L30HtHt x L40htht) e (L30htht $x$ L40htht), seguindo procedimento já descrito em 3.5.2.

As plantas inoculadas foram incubadas durante a noite a uma temperatura de $15^{\circ} \mathrm{C}$ e alta umidade para aumentar a germinação e penetração conidial e, paralelamente, reduzir a dessecação do esporo. Após esse período, foram mantidas em condições naturais de fotoperíodo a uma temperatura diária que variou de $13^{\circ} \mathrm{C}$ a $29^{\circ} \mathrm{C}$. Cerca de 20 dias após a inoculação, foram efetuadas as avaliações quanto ao tipo de lesão, segundo escala proposta por Esteves (1989).

De posse dos resultados obtidos com as linhagens diferenciadoras e com os híbridos isogênicos (L30HtHt $\times$ L40htht) e (L30htht $\times$ L40htht) em casa de vegetação e com os testes de campo conduzidos com esses mesmos híbridos e as linhagens L30HtHt, L30Htht, L30htht e L40htht, foi possivel identificar os espectros de resistência do gene $H t$ e de virulência dos cinco isolados.

\subsection{Fenotipagem de segregantes $R C_{1} F_{1}$ e análise dos segregantes $R C_{1} F_{1}$ agrupados (ASA)}

A confirmação da ligação dos marcadores identificados pela análise de LQIs ao gene introgredido em $\mathrm{L} 30 \mathrm{HtH} t$ foi efetuada através da análise dos segregantes extremos agrupados (ASA) da população [(L30HtHt $\times$ L40htht) $\times$ L40htht], cujos indivíduos foram, inicialmente, fenotipados com vistas a construção dos "bulks" extremos, conforme descrito abaixo.

Visando garantir o polimorfismo fenotípico necessário para o 
mapeamento do referido gene $H t$, a inoculação sobre plantas $R C_{1} F_{1}$ foi efetuada com uma raça avirulenta para o gene $\mathrm{Ht}$ introgredido, porém virulenta para qualquer outro monogene de resistência presente na linhagem recorrente L30htht. Essa informação foi obtida com base nos resultados dos ensaios do item 3.5.2

O preparo de inóculo e a inoculação foram conduzidos mediante adaptações ao procedimento descrito por Simcox \& Bennetzen (1993). Assim, o inóculo de $E$. turcicum foi obtido pela lavagem das culturas do patógeno cultivadas em LCH (Tuite, 1969) por três semanas, no escuro, a uma temperatura de aproximadamente $24^{\circ} \mathrm{C}$. No preparo da suspensão de inóculo foram adicionados $5 \mathrm{ml}$ de água destilada estéril, contendo $0,1 \%$ de Tween 20 à superfície das culturas.

As inoculações foram efetuadas no estádio de 4 a 6 folhas adicionando-se $200 \mu \mathrm{l}$ de uma suspensão de 5000 conídios $/ \mathrm{ml}$ ao cartucho de cada planta (Simcox \& Bennetzen, 1993). A partir disso, as plantas foram colocadas em casa de vegetação sob as condicões de temperatura, umidade $e$ fotoperíodo estabelecidas no item 3.6. Cerca de 15 dias da inoculação, 138 indivíduos segregantes da geração de $R_{1} F_{1}$ foram avaliados, semanalmente, durante um mês, quanto às reações das linhagens para tipo de lesão usando a escala descrita por Esteves (1989). Com base nesses dados, foram gerados dois "bulks" contrastantes, um dos quais foi constituído pela mistura de iguais quantidades de DNA das plantas classificadas como totalmente resistentes $\left(R_{1}\right)$ e o outro das plantas classificadas como suscetiveis $\left(S_{5} / S_{6}\right)$.

Nesta etapa, foram utilizados apenas aqueles marcadores microssatélites informativos, potencialmente ligados ao gene $H t$, que apresentaram contrastes alélicos entre os parentais $\mathrm{L} 10 \mathrm{HtH} / \mathrm{L} 30 \mathrm{htht}$ e entre as "LQIs" L30HtHt/L30htht. Os "bulks" foram subseqüentemente testados para locos marcadores adicionais vizinhos às marcas positivas, visando utilizá-los na etapa de análise molecular das plantas individuais da classe recessiva. A evidência de ligação foi obtida para aqueles locos marcadores que 
apresentaram contrastes alélicos entre os "bulks" $R_{1}$ e $S_{5}$, revelados pela presença de genótipos marcadores heterozigotos para bandas derivadas de ambos parentais ( $\mathrm{L} 3 \mathrm{OH} H \mathrm{Ht}$ e L40htht) e homozigotos para bandas derivadas do parental recorrente suscetível (L40htht), respectivamente.

\subsection{Localização do gene $H t$ pela análise dos indivíduos extremos da classe recessiva}

Para a localização do gene $H t$ na região cromossômica identificada pelas marcas polimórficas positivas, as plantas suscetíveis provenientes do agrupamento da extremidade recessiva da população $R C_{1} F_{1}$ foram genotipadas individualmente. Para tanto, utilizou-se somente os locos de microssatélites que além de apresentarem polimorfismos positivos via LQIs, também foram polimórficos positivos via ASA. Locos marcadores cuja segregação observada dentro da classe suscetível recessiva apresentaram desvios significativos pelo teste $X^{2}$ para a proporção esperada de 1 (genótipo marcador homozigoto recessivo portador da banda do parental suscetível) : 1 (genótipo heterozigoto contendo bandas de ambos parentais) foram considerados ligados ao gene $H t$. Assumindo-se que todas as plantas suscetiveis foram homozigotas para o alelo recessivo do loco alvo $(H t)$, a freqüência de recombinação $\left(c_{1}\right)$ entre um marcador positivo e esse loco foi calculada pelo estimador de máxima verossimilhança (Allard, 1956) $c_{1}=N_{1} / N$, onde $N_{1}$ correspondeu ao número de indivíduos recombinantes que contêm alelos marcadores de ambos os parentais ( $\mathrm{L} 30 \mathrm{HtH}$ e L40htht) e $\mathrm{N}$ ao número total de indivíduos suscetíveis genotipados. As distâncias genéticas de mapa correspondentes foram obtidas mediante aplicação da função de mapeamento de Haldane (1919) sobre os dados de freqüência de recombinação $c_{1}$. O erro associado a $c_{1}$ foi estimado por $V_{c}^{1 / 2}=\left\{\left[c_{1}\left(1-c_{1}\right)\right] / N\right\}$ 


\section{RESULTADOS E DISCUSSÃO}

\subsection{Otimização de protocolos para amplificação de locos de microssatélites em milho}

Um total de 125 pares de "primers" de microssatélites de milho foram analisados, dentre os quais $79(63,2 \%)$ amplificaram produtos de boa qualidade no programa básico (programa 1) da PCR (Senior et al., 1996), independente da temperatura de anelamento ideal calculada pela fórmula de Newton \& Graham (1997). Para os restantes $46(36,8 \%)$ pares de "primers" foi necessário o desenvolvimento de protocolos específicos, ora pela ausência de amplificação ou produção de bandas de qualidade duvidosa, ora pela impossiblidade de discriminar o alelo verdadeiro, naqueles casos onde ocorreu a amplificação de múltiplos fragmentos. A Tabela 2 apresenta protocolos de amplificação para esses 125 pares de "primers", com base em temperaturas de anelamento e concentrações dos "primers". Adicionalmente, são fornecidas as temperaturas de anelamento ideal dos "primers reverse/forward" (R/F), segundo a fórmula descrita em Newton \& Graham (1997), e a posição de cada loco de microssatélite obtida de um mapa consensual de milho disponivel em http:Iluww.agron.missouri.edu.

Durante os ciclos iniciais da PCR, a temperatura de anelamento $\left(T_{A}\right)$ foi reduzida a partir de um valor inicial acima da $T_{A}$ calculada até um valor abaixo da mesma, a fim de que as condições de temperatura pudessem estimular uma ótima hibridização do "amplimer" ao alvo e, conseqüentemente, - "amplicon" desejado pudesse ser amplificado e acumulado antes de qualquer produto indesejado. A fórmula de Newton \& Graham (1997) foi determinada 
Tabela 2 - Temperaturas de anelamento e concentrações de "primers reverse/forward" (R/F) otimizadas para a amplificação de locos de microssatélites em milho.

\begin{tabular}{|c|c|c|c|c|c|c|c|}
\hline LOCO SSR & $\begin{array}{l}\text { LOCO } \\
(\mathrm{BIN})^{/ \mathrm{A}}\end{array}$ & $\begin{array}{l}\text { PROGRAMA } \\
\text { PCR/ ] DE } \\
\text { PRIMERS }\end{array}$ & $\begin{array}{l}\text { T }(C) \text { ANE- } \\
\text { LAMENTO } \\
R / F^{\prime B}\end{array}$ & LOCO SSR & $\begin{array}{l}\text { LOCO } \\
(B \mid N)^{\prime / A}\end{array}$ & $\begin{array}{c}\text { PROGRAMA } \\
\text { PCR/I I DE } \\
\text { PRIMERS }\end{array}$ & $\begin{array}{c}\text { T ( }{ }^{\circ} \text { C)ANE- } \\
\text { LA-MENO } \\
\text { R/F }\end{array}$ \\
\hline$B N G L 149$ & $1.00-1.05$ & $1 / 0,33 \mu M$ & $57 / 65$ & $B N G L 381$ & 2.03 & $1 / 0,165 \mu \mathrm{M}$ & $55 / 61$ \\
\hline PHI056 & 1.01 & $3 / 0,5 \mu \mathrm{M}$ & $59 / 63$ & BNGL 108 & 2.04 & $1 / 0,165 \mu \mathrm{M}$ & $59 / 61$ \\
\hline PHI097 & 1.01 & $1 / 0,33 \mu \mathrm{M}$ & $63 / 67$ & BNGL 121 & 2.04 & $3 / 0,50 \mu \mathrm{M}$ & $61 / 65$ \\
\hline BNGL 109 & 1.02 & $1 / 0,165 \mu M$ & $77 / 77$ & PHIO83 & 2.04 & $1 / 0,165 \mu \mathrm{M}$ & $67 / 69$ \\
\hline BNGL 176 & 1.02 & $1 / 0,165 \mu \mathrm{M}$ & $63 / 67$ & $B N G L 166$ & $2.04 / 8.05$ & $1 / 0,165 \mu \mathrm{M}$ & $55 / 55$ \\
\hline PHIO01 & 1.03 & $2 / 0,165 \mu \mathrm{M}$ & $65 / 69$ & MAGEO5 & $2.05-2.06$ & $4 / 0,33 \mu \mathrm{M}$ & $53 / 59$ \\
\hline BNGL 439 & 1.03 & $1 / 0,165 \mu \mathrm{M}$ & $67 / 77$ & BNGL 180 & 2.06 & $1 / 0,165 \mu \mathrm{M}$ & $51 / 59$ \\
\hline BNGL 147 & 1.03 & $6 / 0,50 \mu \mathrm{M}$ & $57 / 59$ & BNGL 371 & $2.06-2.10$ & $3 / 0,33 \mu \mathrm{M}$ & $55 / 59$ \\
\hline PHI095 & 1.03 & $7 / 0,50 \mu \mathrm{M}$ & $69 / 77$ & BNGL 198 & 2.08 & $3 / 0,33 \mu \mathrm{M}$ & $57 / 65$ \\
\hline BNGL 652 & 1.04 & $2 / 0,33 \mu \mathrm{M}$ & $67 / 69$ & MAG01F03 & 2.08 & $6 / 0,33 \mu M$ & $55 / 59$ \\
\hline BNGL 421 & 1.06 & $1 / 0,165 \mu \mathrm{M}$ & $55 / 57$ & MAG01A01 & 2.08 & $6 / 0,50 \mu \mathrm{M}$ & $53 / 55$ \\
\hline BNGL 615 & 1.07 & $1 / 0,165 \mu \mathrm{M}$ & $75 / 79$ & BNGL 602 & 3.04 & $1 / 0,165 \mu \mathrm{M}$ & $69 / 69$ \\
\hline $\begin{array}{l}\text { MACEOT } \\
\text { F06 }\end{array}$ & 1.08 & $1 / 0,165 \mu \mathrm{M}$ & $53 / 59$ & PHIO29 & 3.04 & $1 / 0,165 \mu \mathrm{M}$ & $77 / 77$ \\
\hline PHI055 & 1.09 & $2 / 0,165 \mu \mathrm{M}$ & $59 / 61$ & $\mathrm{PHIO73}$ & 3.05 & $1 / 0,165 \mu \mathrm{M}$ & $69 / 77$ \\
\hline PHIO94 & 1.09 & $2 / 0,33 \mu \mathrm{M}$ & $59 / 63$ & BNGL 420 & 3.05 & $1 / 0,165 \mu \mathrm{M}$ & $57 / 57$ \\
\hline BNGL 100 & 1.09 & $1 / 0,165 \mu \mathrm{M}$ & $61 / 65$ & MAG01A03 & 3.06 & $1 / 0,165 \mu \mathrm{M}$ & $53 / 53$ \\
\hline PHI011 & 1.09 & $1 / 0,165 \mu \mathrm{M}$ & $63 / 63$ & BNGL 197 & 3.07 & $1 / 0,165 \mu \mathrm{M}$ & $57 / 57$ \\
\hline BNGL 400 & $1.10-1.12$ & $3 / 0,33 \mu \mathrm{M}$ & $57 / 59$ & BNGL 372 & $4.00-4.04$ & $6 / 0,50 \mu \mathrm{M}$ & $57 / 61$ \\
\hline BNGL 504 & 1.11 & $1 / 0,165 \mu \mathrm{M}$ & $67 / 67$ & PHIO72 & 4.01 & $1 / 0,165 \mu \mathrm{M}$ & $67 / 75$ \\
\hline BNGL 131 & 1.11 & $1 / 0,165 \mu \mathrm{M}$ & $55 / 63$ & PHIO21 & 4.03 & $1 / 0,165 \mu \mathrm{M}$ & $75 / 81$ \\
\hline PHI064 & 1.11 & $1 / 0,165 \mu \mathrm{M}$ & $71 / 71$ & PHIO74 & 4.04 & $1 / 0,165 \mu \mathrm{M}$ & $65 / 71$ \\
\hline BNGL 257 & 1.12 & $1 / 0,165 \mu \mathrm{M}$ & $64 / 64$ & BNGL 490 & 4.05 & $1 / 0,165 \mu \mathrm{M}$ & $63 / 65$ \\
\hline BNGL 469 & $\begin{array}{c}2.02 / 7.05 \\
9.03\end{array}$ & $2 / 0,33 \mu \mathrm{M}$ & $63 / 65$ & BNGL 252 & 4.05 & $1 / 0,165 \mu \mathrm{M}$ & $79 / 87$ \\
\hline$B N G L 125$ & 2.03 & $1 / 0,67 \mu \mathrm{M}$ & $57 / 61$ & MTTGBO2 & $4.06-4.07$ & $1 / 0,165 \mu M$ & $49 / 53$ \\
\hline
\end{tabular}

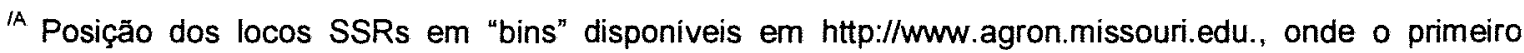
número do "bin" fornece o grupo de ligação e o segundo, a posição do "bin" dentro do grupo de ligação ${ }^{18}$ temperatura de anelamento estimada segundo a fórmula encontrada em Newton \& Graham (1997) para as seqüências dos "primers reverse/forward" disponiveis em http:llwww.agron.missouri.edu. 
(continuação da Tabela 2)

\begin{tabular}{|c|c|c|c|c|c|c|c|}
\hline LOCO SSR & $\begin{array}{l}\angle O C O \\
(B I N)^{/ A}\end{array}$ & $\begin{array}{l}\text { PROGRAMA } \\
\text { PCR/ I DE } \\
\text { PRIMERS }\end{array}$ & $\begin{array}{c}\left.\text { T( }{ }^{\circ} \mathrm{C}\right) \text { ANE- } \\
\text { LA MENTO } \\
\text { R/F }^{\prime 8}\end{array}$ & LOCO SSR & $\begin{array}{l}\text { LOCO } \\
(\mathrm{BIN})^{/ A}\end{array}$ & $\begin{array}{c}\text { PROGRAM } \\
\text { APCRII } \\
\text { DE } \\
\text { PRIMERS }\end{array}$ & $\begin{array}{c}\text { T }(\text { C)ANE } \\
\text { LAMENO } \\
\text { R/F }^{\prime B}\end{array}$ \\
\hline PHIO92 & 4.08 & $1 / 0,165 \mu \mathrm{M}$ & $59 / 61$ & PHIOT7 & 6.01 & $1 / 0.165 \mu \mathrm{M}$ & $65 / 67$ \\
\hline $\begin{array}{c}\text { MAGTO1 } \\
\text { HO7 }\end{array}$ & 4.08 & $3 / 1,00 \mu \mathrm{M}$ & $57 / 57$ & BNGL 107 & 6.01 & $1 / 0,50 \mu \mathrm{M}$ & $73 \sqrt{77}$ \\
\hline BNGL292 & $4.09 / 9.06$ & $6 / 0,50 \mu \mathrm{M}$ & $57 / 61$ & BNGL 480 & 6.04 & $3 / 0,33_{\mu} \mathrm{M}$ & $65 / 65$ \\
\hline PHIO06 & 4.10 & $1 / 0,165 \mu \mathrm{M}$ & $61 / 63$ & NC012 & 6.05 & $1 / 0,165 \mu \mathrm{M}$ & $53 / 57$ \\
\hline BNGL 589 & 4.10 & $1 / 0,165 \mu \mathrm{M}$ & $77 / 81$ & PHI078 & 6.05 & $3 / 0,50 \mu \mathrm{M}$ & $61 / 69$ \\
\hline PHIO24 & 5.00 & $1 / 0,165 \mu \mathrm{M}$ & $69 / 71$ & PHI081 & 6.05 & $2 / 0,165 \mu \mathrm{M}$ & $59 / 65$ \\
\hline NCO07 & 5.00 & $6 / 0,165 \mu \mathrm{M}$ & $53 / 55$ & $B N G L 345$ & 6.05 & $1 / 0,165 \mu \mathrm{M}$ & $57 / 65$ \\
\hline $\begin{array}{c}\text { MACEOO } \\
B 03\end{array}$ & 5.01 & $8 / 0,50 \mu M$ & $49 / 53$ & MACTO2E01 & 6.06 & $8 / 0,50 \mu \mathrm{M}$ & $51 / 61$ \\
\hline BNGL 143 & 5.01 & $1 / 0,165 \mu \mathrm{M}$ & $61 / 69$ & PHI070 & 6.07 & $3 / 0,50 \mu \mathrm{M}$ & $59 / 63$ \\
\hline PHI 113 & 5.02 & $1 / 0,165 \mu M$ & $59 / 67$ & PHI 057 & 7.01 & $1 / 0,165 \mu \mathrm{M}$ & $61 / 61$ \\
\hline BNGL 105 & 5.03 & $1 / 0,165 \mu \mathrm{M}$ & $59 / 61$ & PHIO34 & 7.01 & $1 / 1,00 \mu \mathrm{M}$ & - \\
\hline$B N G L 557$ & 5.03 & $6 / 0,50 \mu \mathrm{M}$ & $55 / 61$ & $B N G L 398$ & 7.02 & $1 / 0,33 \mu \mathrm{M}$ & $57 / 57$ \\
\hline PHI008 & 5.03 & $6 / 0,33 \mu \mathrm{M}$ & $55 / 59$ & BNGL 434 & 7.03 & $1 / 0,33 \mu \mathrm{M}$ & $55 / 57$ \\
\hline BNGL 150 & $5.03 / 5.04$ & $1 / 0,165 \mu \mathrm{M}$ & $51 / 55$ & BNGL 155 & 7.03 & $1 / 0,165 \mu \mathrm{M}$ & $57 / 61$ \\
\hline BNGL 603 & 5.04 & $7 / 0,50 \mu \mathrm{M}$ & $67 / 73$ & BNGL339 & $7.03-7.06$ & $1 / 0,165 \mu \mathrm{M}$ & $57 / 61$ \\
\hline$B N G L 653$ & 5.04 & $2 / 0,33 \mu \mathrm{M}$ & $71 / 73$ & MACE01G01 & $7.03-7.04$ & $1 / 0,165 \mu \mathrm{M}$ & $57 / 57$ \\
\hline $\begin{array}{c}\text { MACEO1 } \\
A 03\end{array}$ & 5.04 & $4 / 0,33 \mu \mathrm{M}$ & $49 / 50$ & $B N G L 469$ & $\begin{array}{c}7.05 / 2.021 \\
9.03\end{array}$ & $2 / 0,33 \mu \mathrm{M}$ & $63 / 65$ \\
\hline BNGL 278 & 5.06 & $1 / 0,165 \mu \mathrm{M}$ & $57 / 57$ & MACE01F07 & 7.05 & $1 / 0,165 \mu \mathrm{M}$ & $47 / 61$ \\
\hline BNGL 609 & 5.06 & $2 / 0,50 \mu \mathrm{M}$ & $67 / 69$ & $B N G L 572$ & $7.04-7.06$ & $3 / 0,33 \mu \mathrm{M}$ & $59 / 61$ \\
\hline PHI 085 & 5.07 & $3 / 0,50 \mu \mathrm{M}$ & $61 / 63$ & PHI082 & 7.06 & $1 / 0,165 \mu M$ & $53 / 67$ \\
\hline BNGL 118 & 5.08 & $1 / 0,165 \mu \mathrm{M}$ & $53 / 55$ & MACE01C08 & 8.02 & $6 / 0,50 \mu \mathrm{M}$ & $55 / 55$ \\
\hline BNGL 389 & 5.09 & $1 / 0,165 \mu \mathrm{M}$ & $57 / 57$ & $B N G L 669$ & 8.03 & $1 / 0,165 \mu \mathrm{M}$ & $69 / 69$ \\
\hline$B N G L 386$ & 5.09 & $1 / 0,165 \mu \mathrm{M}$ & $55 / 61$ & BNGL 119 & 8.04 & $1 / 0,165 \mu \mathrm{M}$ & $57 / 61$ \\
\hline PHIO75 & 6.00 & $1 / 0,165 \mu \mathrm{M}$ & $67 / 77$ & PHI 060 & 8.04 & $2 / 0,33_{\mu} \mathrm{M}$ & $63 / 67$ \\
\hline$B N G L 238$ & 6.01 & $1 / 0,165 \mu \mathrm{M}$ & $73 / 79$ & PHI 115 & 8.04 & $1 / 0,165 \mu \mathrm{M}$ & $65 / 65$ \\
\hline
\end{tabular}

IA Posição dos locos SSRs em "bins" disponiveis em http://wuw.agron.missouri.edu., onde o primeiro número do "bin" fornece o grupo de ligação e o segundo, a posição do "bin" dentro do grupo de ligação ${ }^{18}$ temperatura de anelamento estimada segundo a fórmula encontrada em Newton \& Graham (1997) para as seqüências dos "primers reverse/forward" disponiveis em http:llwww.agron.missouri.edu. 
(continuação da Tabela 2)

\begin{tabular}{|c|c|c|c|c|c|c|c|}
\hline LOCO SSR & $\begin{array}{l}\text { LOCO } \\
(\mathrm{BIN})^{\prime \mathbf{A}}\end{array}$ & $\begin{array}{l}\text { PROGRAMA } \\
\text { PCR/ ] DE } \\
\text { PRIMERS }\end{array}$ & $\begin{array}{l}\text { T/C)ANE- } \\
\text { LAMENTO } \\
\text { R/F }\end{array}$ & LOCO SSR & $\begin{array}{l}\text { LOCO } \\
(B I N)^{/ A}\end{array}$ & $\begin{array}{c}\text { PROGRAM } \\
\text { A PCR/[ ] } \\
\text { DE } \\
\text { PRIMERS }\end{array}$ & $\begin{array}{c}\text { T/C)ANE- } \\
\text { LAMENO } \\
\text { R/F }\end{array}$ \\
\hline PHIO14 & 8.04 & $1 / 0,165 \mu \mathrm{M}$ & $69 / 77$ & PHIO59 & 10.02 & $1 / 0,165 \mu \mathrm{M}$ & $61 / 67$ \\
\hline BNGL162 & 8.05 & $1 / 0,165 \mu \mathrm{M}$ & $73 / 75$ & PHI063 & 10.02 & $1 / 0,33 \mu \mathrm{M}$ & $55 / 65$ \\
\hline BNGL166 & 8.05 & $1 / 0,165 \mu \mathrm{M}$ & $55 / 55$ & BNGL210 & 10.03 & $1 / 0.165 \mu \mathrm{M}$ & $57 / 57$ \\
\hline BNGL240 & 8.06 & $1 / 0,165 \mu \mathrm{M}$ & $57 / 61$ & PHIO62 & 10.04 & $1 / 0,165 \mu M$ & $63 / 65$ \\
\hline PHI015 & 8.08 & $1 / 0,165 \mu \mathrm{M}$ & $63 / 67$ & PHI071 & 10.04 & $1 / 0,33 \mu \mathrm{M}$ & $65 / 67$ \\
\hline MACE01C01 & 8.08 & $4 / 0,33 \mu \mathrm{M}$ & $53 / 57$ & PHIO84 & 10.04 & $1 / 0,33 \mu \mathrm{M}$ & $63 / 67$ \\
\hline BNGL469 & $\begin{array}{c}9.03 / 2.02 / \\
7.05\end{array}$ & $2 / 0,33 \mu \mathrm{M}$ & $63 / 65$ & BNGL640 & 10.04 & $2 / 0,50 \mu \mathrm{M}$ & $69 / 71$ \\
\hline MACT02B08 & $9.01-9.02$ & $1 / 0,165 \mu \mathrm{M}$ & $55 / 59$ & BNGL137 & 10.05 & $6 / 0.50 \mu \mathrm{M}$ & $55 / 55$ \\
\hline PHIO33 & 9.01 & $2 / 0,33 \mu \mathrm{M}$ & $67 / 69$ & BNGL153 & 10.06 & $2 / 0,33 \mu \mathrm{M}$ & $57 / 59$ \\
\hline BNGL 244 & 9.02 & $2 / 0,33 \mu \mathrm{M}$ & $63 / 69$ & BNGL236 & 10.06 & $3 / 0,50 \mu \mathrm{M}$ & $65 / 65$ \\
\hline PHI065 & 9.03 & $1 / 0,165 \mu \mathrm{M}$ & $67 / 67$ & BNGL594 & 10.06 & $5 / 0,50_{\mu} M$ & $69 / 79$ \\
\hline$B N G L 127$ & 9.04 & $1 / 0,165 \mu M$ & $57 / 61$ & BNGL279 & 10.07 & $4 / 0,33 \mu \mathrm{M}$ & $55 / 55$ \\
\hline$B N G L 430$ & 9.04 & $1 / 0,165 \mu \mathrm{M}$ & $61 / 69$ & $\begin{array}{c}\text { MACTO2 } \\
\text { B10 }\end{array}$ & & $1 / 0,165 \mu \mathrm{M}$ & $55 / 59$ \\
\hline BNGL292 & $9.06-4.09$ & $6 / 0,50 \mu \mathrm{M}$ & $57 / 61$ & MAGB01 & & $3 / 0,33 \mu \mathrm{M}$ & 55.159 \\
\hline $\begin{array}{c}\text { MAGT01 } \\
\text { D06 }\end{array}$ & $9.06-9.07$ & $8 / 0,50 \mu \mathrm{M}$ & $51 / 53$ & MAG1C05 & & $1 / 0,165 \mu \mathrm{M}$ & $55 / 63$ \\
\hline$B N G L 128$ & 9.07 & $1 / 0,165 \mu \mathrm{M}$ & $61 / 65$ & & & & \\
\hline
\end{tabular}

IA Posição dos locos SSRs em "bins" disponiveis em http://www.agron.missouri.edu., onde o primeiro número do "bin" fornece o grupo de ligação e o segundo, a posição do "bin" dentro do grupo de ligação ${ }^{18}$ temperatura de anelamento estimada segundo a fórmula encontrada em Newton \& Graham (1997) para as seqüências dos "primers reverse/forward" disponiveis em http:llwww.agron.missouri.edu.

para testes de hibridização com oligonucleotideos a uma concentração de sal de $1 \mathrm{M}$. Nessas condições, os autores ressaltam que as estimativas poderiam não ser tão exatas para "primers" constituídos por mais de 20 nucleotídeos, tal como ocorre com os "primers" de microssatélites. Essa é a razão pela qual alguns laboratórios têm usado temperaturas de anelamento de $3^{\circ} \mathrm{C}$ a $5^{\circ} \mathrm{C}$ abaixo da temperatura calculada pela referida fórmula. Entretanto, ainda que o ajuste de $-5^{\circ} \mathrm{C}$ tenha sido adotado, constatou-se que alguns programas da PCR que geraram as melhores amplificações utilizaram temperaturas de anelamento 
fora da faixa estimada para o par de "primers" analisado (BNGL109, BNGL615, PHI055, PHI064, MAG01A01, BNGL602, PHI029, PHI073, PHI021, BNGL252, BNGL589, PHI024, PHI094 MACE01A03, BNGL238, BNGL107, BNGL669, PHI014, BNGL162, BNGL153) ou, pelo menos, para um dos componentes do par (MACE01F07, BNGL439, PHI083, BNGL180, BNGL371, PHI072, PHI074, MTTGB02, BNGL143, BNGL150, PHI075, PHI078, PHI081, BNGL430, BNGL594, MAGB01).

Ainda que alguns locos de microssatélites analisados não tenham apresentado as melhores resoluções ou até mesmo não tenham amplificado dentro da faixa de temperatura compreendida pelos seus respectivos pares de "primers" (reverse/foward), considerou-se que as temperaturas de anelamento estimadas pela referida fórmula foram válidas. Isso decorre das $T_{A S}$ calculadas terem servido, pelo menos, como ponto de partida para os experimentos de otimização da PCR, além de terem tornado as etapas iniciais de testes menos empíricas. A própria literatura especializada tem indicado que a temperatura ideal de anelamento nem sempre está bem correlacionada com a $T_{A}$ estimada $e$ que, em alguns casos, a temperatura de anelamento ideal pode estar acima desse valor estimado (Newton \& Graham, 1997).

As melhores reações de amplificação ocorreram com aqueles locos, cujos "primers reverse/forward" possuem uma temperatura de anelamento similar, tal como observado com PHI011, PHI057, PHI062, PHI071, PHI077, PHI083, BNGL105, BNGL118, BNGL197, BNGL257, BNGL420, BNGL398, BNGL389, BNGL434, BNGL504, MACE01G01 (programa 1), BNGL469, BNGL640, BNGL653, PHI033, PHI055 (programa 2), MACT01H07, BNGL236, BNGL480, BNGL572, PHI085 (programa 3), BNGL279 (programa 4), BNGL147, NC007, MACE01C08 (programa 6), dentre outros (Tabela 2). Por outro lado, muitos pares de "primers" apresentaram uma amplificação de boa qualidade dentro de uma faixa de temperatura relativamente mais ampla, uma vez que mais de um programa de amplificação foi capaz de produzir "amplicons" desejáveis (PHI095, PHI094, BNGL589, MACE01C01, MAGB01 e BNGL594, 
dentre outros). Diferenças resultantes da qualidade do DNA extraído também podem explicar a capacidade de certos "primers" gerarem "amplicons" desejáveis quando submetidos a programas de amplificação diferentes daqueles sugeridos no presente trabalho.

A Figura 3 ilustra o efeito da temperatura de anelamento e/ou da concentração de "primers" na reação de amplificação de alguns locos de microssatélites. O loco amplificado pelo par de "primers" PHI033, por exemplo, mostrou que a melhor intensidade de banda resultou, principalmente, da otimização da temperatura de anelamento (programa2/0,33 $\mu \mathrm{M}$ vs. programa $1 / 0,33 \mu \mathrm{M}$ ) durante o programa de amplificação. Além disso, em contraste à crescente intensidade de produtos diméricos ("bandas fantasmas") observada com o aumento da concentração do par de "primers" no programa 1 (programa 1 a 0,$165 ; 0,33$ e 1,0 $\mu \mathrm{M}$ ), as temperaturas de anelamento conferidas pelo programa 2 (programa $2 / 0,33 \mu \mathrm{M}$ ) foram consideradas mais eficientes. Contudo, esse é um problema intrínseco à técnica, quando os terminais $3^{\prime}$ dos "primers" apresentam seqüências complementares (Newton \& Graham, 1997).

Também foi constatada a situação extrema de locos que apresentam bandas desejáveis apenas em condições específicas de amplificação, tal como ocorreu com o loco MAG01D06, o qual amplificou no programa 4 a $0,33 \mu \mathrm{M}$ e não amplificou nas mesmas concentrações de "primers" no programa 1. O par de "primers" BNGL603, por sua vez, amplificou múltiplos fragmentos quando testado sob várias $T_{A S}$ e somente o programa $7 / 0,5 \mu \mathrm{M}$ permitiu a discriminação do verdadeiro alelo e diminuição da quantidade de bandas artificiais. A amplificação de múltiplos produtos (bandas "stutter") resulta de falhas da polimerase sobre a fita molde durante a polimerização ("slippage") (Brown, 1996; Litt \& Lutty, 1989; Weber \& May, 1989) e é bastante comum aos motivos repetidos compostos por dinucleotídeos. Os locos amplificados pelos pares de "primers" BNGL603, BNGL371, BNGL609, BNGL244, MAGT01D06, BNGL137, BNGL279, BNGL652 e MACT02E01 estão 

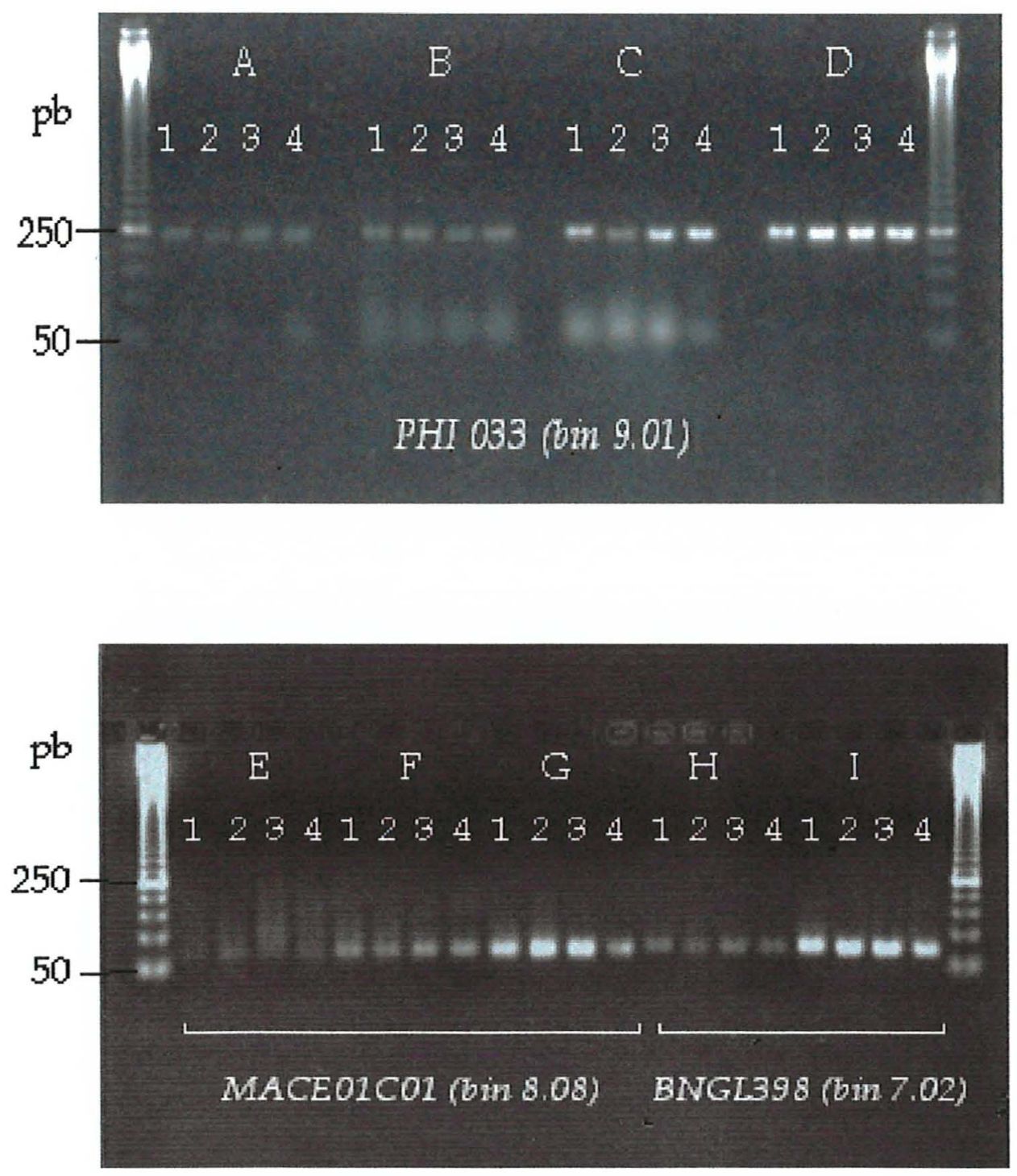

Figura 3 - Comparação entre protocolos de amplificação nos programas 1/ $0,165 \mu \mathrm{M}$ de "primer" (A); 1/0,33 $\mu \mathrm{M}$ (B); 1/1,00 $\mu \mathrm{M}$ (C) e 2/0,33 $\mu \mathrm{M}$ (D) com o loco de microssatélite PHI033; nos programas 1/0,165 $\mu \mathrm{M}(\mathrm{E}), 4 / 0,165 \mu \mathrm{M}(\mathrm{F}), 4 / 0,33 \mu \mathrm{M}(\mathrm{G})$ com o loco MACE01C01 e; $1 / 0,165 \mu \mathrm{M}(\mathrm{H})$ e $1 / 0,33 \mu \mathrm{M}$ (I) com o loco BNGL398. Protocolos testados para a variedade L10HtHt (1) e as linhagens L30HtHt (2), L30htht (3) e L30Htht (4) de milho. 
dentro dessa classe, uma vez que são constituídos por seqüências repetidas CT/AG, AC/GT, CT/AG, GAITC, GA/TC, CA/TG, AG/CT, CT/AG e CATTG, respectivamente. Segundo relatos de Newton \& Graham (1997), alguns dos procedimentos indicados para superar esse problema seria pela redução do número de ciclos da PCR e da concentração de "primers" da reação de amplificação. No presente trabalho, entretanto, a redução na geração de bandas múltiplas de alguns locos marcadores deveu-se, basicamente, à mudanças na temperatura de anelamento durante os ciclos da PCR.

As concentrações de "primers" analisadas no presente trabalho estiveram dentro do intervalo compreendido de $0,165 \mu \mathrm{M}$ a $1,00 \mu \mathrm{M}$, sendo o limite superior definido com base em protocolo descrito por Chin et al. (1996). Ainda que os testes com diferentes concentrações de "primers" tenham sido conduzidos de forma empírica, ficou bastante evidente o aumento da qualidade do produto da PCR à medida que foram alteradas as concentrações dos mesmos na reação de amplificação. Alterações na concentração desse componente da reação resultaram em mudanças na eficiência da reação de amplificação e produziram bandas que variaram em presença/ausência e intensidade (BNGL398 e PHIO33, Figura 3).

4.2 Análise genética de linhagens quase isogênicas (LQls) de milho para um gene de resistência a Exserohilum turcicum

A análise genotípica do parental doador L10HtHt (PD) e das linhagens quase isogênicas convertida L30HtHt (LQI) e recorrente L30htht (PR) mediante marcadores moleculares do tipo microssatélites, permitiu identificar 61 locos polimórficos entre PR/PD dentre 125 marcadores analisados nos 10 cromossomos do milho (Tabelas 3 e 4). Esses 61 casos informativos de contrastes alélicos entre $\mathrm{L} 10 H \mathrm{H} H \mathrm{H} / \mathrm{L} 30 \mathrm{htht}$ serviram tanto para a determinação da proporção recuperada do genoma do parental recorrente na LQI convertida $(\mathrm{L} 30 \mathrm{H} t \mathrm{Ht})$, bem como para a identificação de marcadores putativamente ligados 


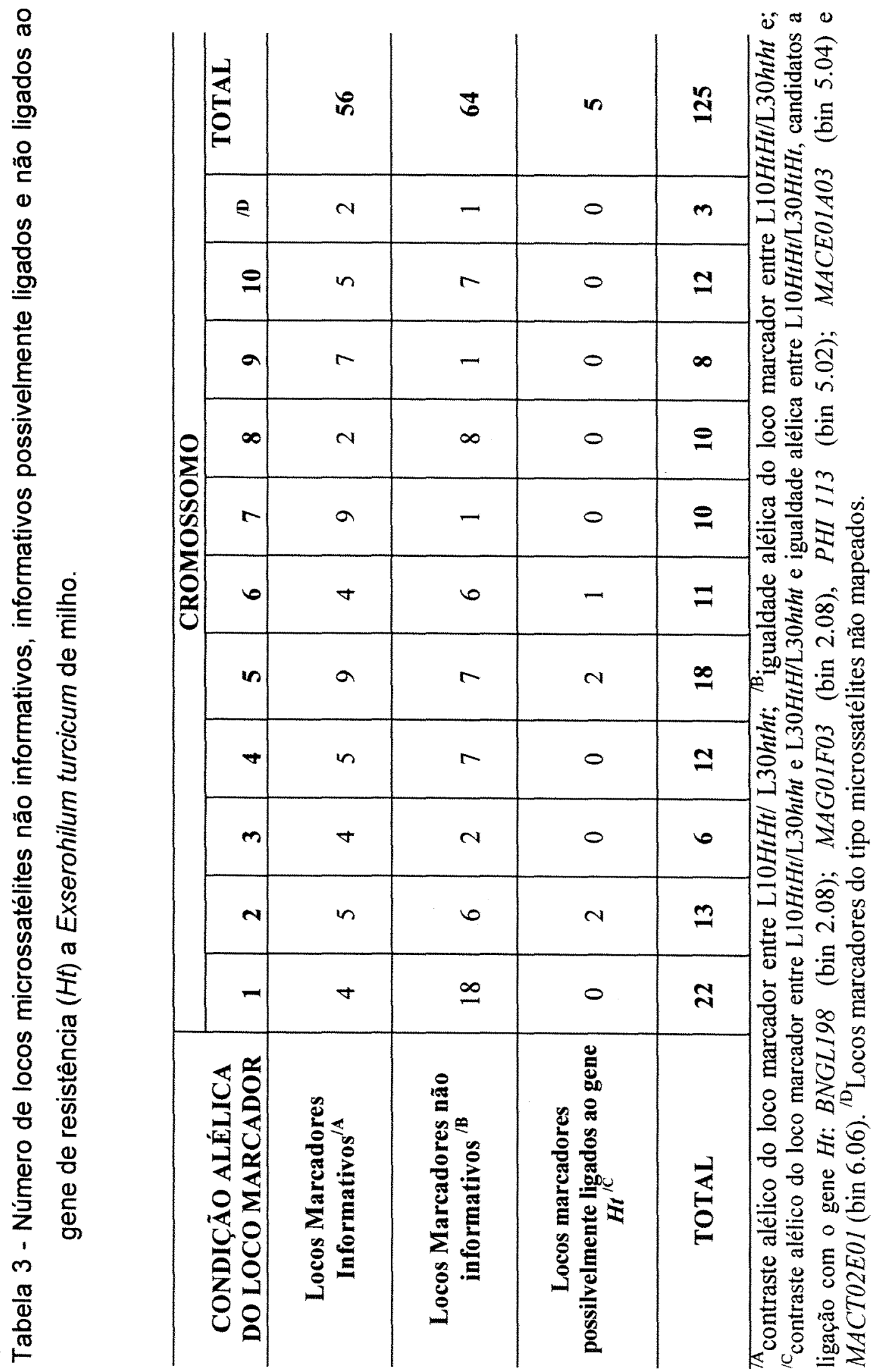


Tabela 4 - Análise de linhagens quase isogênicas de milho para locos microssatélites não informativos (-), informativos possivelmente não ligados $\left(^{+}\right)$e ligados $\left(^{*}\right)$ ao gene de resistência $(H t)$ a $E$. turcicum.

\begin{tabular}{|c|c|c|c|c|c|c|c|c|c|c|c|}
\hline LOCO SSR & $\begin{array}{l}\text { LOCO } \\
\left({ }^{\prime} B \mid N^{n}\right)^{\prime A}\end{array}$ & $\begin{array}{c}\mathrm{L} 1 \mathrm{OHT} / \\
\mathrm{L}^{\prime} \mathrm{O}^{\prime \prime}\end{array}$ & $\begin{array}{l}\mathrm{L} 10 \mathrm{HT} / \\
\mathrm{L}_{30 \mathrm{HT}}{ }^{\mathrm{BB}}\end{array}$ & $\underset{\mathrm{L}^{2} 0^{\prime 8}}{\mathrm{~L} 3 \mathrm{OHT} /}$ & $\begin{array}{l}(+) \\
(-) \\
()^{\prime c}\end{array}$ & LOCO SSR & $\begin{array}{l}\text { LOCO } \\
\left(\text { (BIN") }^{\prime A}\right.\end{array}$ & $\underset{\mathrm{L}_{30} \mathrm{O}^{\prime \mathrm{B}}}{\mathrm{L} 10 \mathrm{HT} /}$ & $\begin{array}{l}\text { L10HT/ } \\
\text { L3OHT }^{\prime 8}\end{array}$ & $\begin{array}{c}\mathrm{L} 30 \mathrm{HT} / \\
\mathrm{L}^{\prime} 30^{\prime \mathrm{B}}\end{array}$ & $\begin{array}{l}(+) \\
(-) \\
(0)^{\prime C}\end{array}$ \\
\hline$B N G L 149$ & $1.00-1.05$ & $\mathrm{~N}$ & $\mathrm{~N}$ & $\mathrm{~N}$ & $(-)$ & $B N G L I 25$ & 2.03 & $S$ & $S$ & $\mathbf{N}$ & $(+)$ \\
\hline PHI 056 & 1.01 & $\mathrm{~N}$ & $\mathbf{N}$ & $\mathbf{N}$ & $(-)$ & $B N G L 381$ & 2.03 & $\mathbf{N}$ & $\mathrm{N}$ & $\mathrm{N}$ & $(-)$ \\
\hline PHI 097 & 1.01 & $S$ & $\mathrm{~S}$ & $N$ & $(+)$ & $B N G L I 08$ & 2.04 & $\bar{N}$ & $\mathbf{N}$ & $\bar{N}$ & $(\cdot)$ \\
\hline$B N G L 109$ & 1.02 & $\mathrm{~N}$ & $N$ & $N$ & $(-)$ & $B N G L 121$ & 2.04 & $\mathrm{~N}$ & $\mathbf{N}$ & $\mathrm{N}$ & $(-)$ \\
\hline$B N G L 176$ & 1.02 & $\bar{N}$ & $\bar{N}$ & $\mathrm{~N}$ & $(-)$ & PHI 083 & 2.04 & $\mathbf{N}$ & $\bar{N}$ & $\mathbf{N}$ & $(-)$ \\
\hline PHI $00 \mathrm{I}$ & 1.03 & $S$ & $\mathrm{~S}$ & $\mathrm{~N}$ & $(+)$ & $B N G L 166$ & $2.04 / 8.05$ & $\mathrm{~S}$ & $S$ & $\bar{N}$ & $(+)$ \\
\hline$B N G L 439$ & 1.03 & $S$ & $\mathrm{~S}$ & $\mathrm{~N}$ & $(+)$ & $M A G E 05$ & $2.05-2.09$ & $S$ & $\mathrm{~S}$ & $\mathrm{~N}$ & $(+)$ \\
\hline$B N G L 147$ & 1.03 & $\mathrm{~N}$ & $\mathbf{N}$ & $\mathrm{N}$ & $(-)$ & $B N G L I 80$ & 2.06 & $S$ & S & $\mathbf{N}$ & $(+)$ \\
\hline PHI 095 & 1.03 & $\bar{N}$ & $\mathrm{~N}$ & $\mathbf{N}$ & $(-)$ & BNGL37I & $2.06-2.10$ & $\bar{N}$ & $\bar{N}$ & $\bar{N}$ & $(-)$ \\
\hline$B N G L 652$ & 1.04 & $\mathrm{~S}$ & $s$ & $\mathrm{~N}$ & $(+)$ & $B N G L 198$ & 2.08 & S & $\bar{N}$ & $S$ & $(*)$ \\
\hline$B N G L 421$ & 1.06 & $\mathrm{~N}$ & $\bar{N}$ & $\mathrm{~N}$ & $(-)$ & $\begin{array}{c}\text { MAG0I } \\
F 03\end{array}$ & 2.08 & $\bar{S}$ & $\mathrm{~N}$ & $\bar{S}$ & $\left(^{*}\right)$ \\
\hline$B N G L 615$ & 1.07 & $\mathbf{N}$ & $N$ & $\mathrm{~N}$ & $(-)$ & $\begin{array}{c}M A G 0 I \\
A 0 I\end{array}$ & 2.08 & $\mathbf{N}$ & $\mathrm{N}$ & $\mathbf{N}$ & $(-)$ \\
\hline $\begin{array}{c}\text { MACEOI } \\
F 06\end{array}$ & 1.08 & $\mathrm{~N}$ & $\mathbf{N}$ & $N$ & $(-)$ & $B N G L 602$ & 3.04 & $S$ & $\mathbf{S}$ & $\mathbf{N}$ & $(+)$ \\
\hline PHI 055 & 1.09 & $\mathrm{~N}$ & $\mathrm{~N}$ & $\mathrm{~N}$ & $(-)$ & PHI 029 & 3.04 & $\mathrm{~N}$ & $\mathrm{~N}$ & $\mathrm{~N}$ & $(-)$ \\
\hline PHI 094 & 1.09 & $\bar{N}$ & $\overline{\mathbf{N}}$ & $\mathrm{N}$ & $(-)$ & PHI 073 & 3.05 & $\bar{S}$ & $\mathrm{~S}$ & $\mathrm{~N}$ & $(+)$ \\
\hline$B N G L 100$ & 1.09 & $\bar{N}$ & $\bar{N}$ & $\mathrm{~N}$ & $(-)$ & $B N G L 420$ & 3.05 & $\bar{N}$ & $\mathrm{~N}$ & $\bar{N}$ & $(-)$ \\
\hline PHIOII & 1.09 & $\mathbf{N}$ & $\mathrm{N}$ & $\mathrm{N}$ & $(-)$ & $\begin{array}{c}M A G 01 \\
A 03\end{array}$ & 3.06 & $S$ & $\mathrm{~S}$ & $N$ & $(+)$ \\
\hline$B N G L 400$ & $1.10-1.12$ & $\mathrm{~N}$ & $\mathrm{~N}$ & $\mathrm{~N}$ & $(-)$ & $B N G L 197$ & 3.07 & $S$ & $\bar{S}$ & $\mathrm{~N}$ & $(+)$ \\
\hline BNGL 504 & 1.11 & $\mathbf{N}$ & $\mathbf{N}$ & $\mathrm{N}$ & $(-)$ & $B N G L 372$ & $4.00-4.04$ & $\bar{N}$ & $\mathrm{~N}$ & $\mathrm{~N}$ & $(-)$ \\
\hline$B N G L / 3 I$ & 1.11 & $\bar{N}$ & $\mathrm{~N}$ & $\mathrm{~N}$ & $(-)$ & PHI 072 & 4.01 & $\mathbf{N}$ & $\mathrm{N}$ & $\mathrm{N}$ & $(-)$ \\
\hline PHI 064 & 1.11 & $\bar{N}$ & $\bar{N}$ & $\overline{\mathrm{N}}$ & $(-)$ & PHI 02I & 4.03 & $\bar{N}$ & $\bar{N}$ & $\mathrm{~N}$ & $(-)$ \\
\hline$B N G L 257$ & 1.12 & $\mathrm{~N}$ & $\mathrm{~N}$ & $N$ & $(-)$ & PHIO74 & 4.04 & $\bar{S}$ & $\mathrm{~S}$ & $\bar{N}$ & $(+)$ \\
\hline$B N G L 469$ & $\begin{array}{c}2.02 / 7.05 \\
9.03\end{array}$ & $S$ & S & $\mathrm{N}$ & $(+)$ & $B N G L 490$ & 4.05 & S & $S$ & $\bar{N}$ & $(+)$ \\
\hline
\end{tabular}

${ }^{14}$ Posiçäo dos locos SSRs disponiveis em http:lluww.agron.missouriedu; ${ }^{18}(\mathbf{N})$ : ausència de contrate alélico no loco marcador; (S) : presença de contraste alélico; ${ }^{\prime C}(-)$ : loco marcador näo informativo (ausência de contraste alélico entre L10HtHt L.30htht); (+): provável independência entre loco marcador e gene alvo (contrate alélico entre L10HtHt/L30htht e igualdade alélica L3OHtHtL30htht); $\left(^{*}\right)$ : possivel ligação entre loco marcador e gene alvo (presença de contraste alélico entre L10HtHtL30htht e igualdade alélica entre L10HtHt/L3OHtHt). 
(continuação da Tabela 4)

\begin{tabular}{|c|c|c|c|c|c|c|c|c|c|c|c|}
\hline LOCO SSR & $\begin{array}{c}\mathrm{LOCO} \\
\left({ }^{\prime} \mathrm{B} B \mathrm{~N}^{\prime}\right)^{\prime A}\end{array}$ & $\begin{array}{l}\mathrm{L} 10 \mathrm{OHT} / \\
\mathrm{L} 30^{\mathrm{BB}}\end{array}$ & $\begin{array}{l}\text { L10HT/ } \\
\text { L3OHT' }\end{array}$ & $\begin{array}{l}\mathrm{L} 30 \mathrm{HTI} \\
\mathrm{L} 30^{8 B}\end{array}$ & $\begin{array}{l}(+) \\
(-) \\
()^{\prime \prime C}\end{array}$ & LOCO SSR & $\begin{array}{l}\text { LOCO } \\
(" B I N)^{I A}\end{array}$ & $\begin{array}{l}\mathrm{L} 10 \mathrm{HT} / \\
\mathrm{L} 3 \mathrm{O}^{\mathrm{B}} \mathrm{I}\end{array}$ & $\begin{array}{l}\mathrm{LOHT/T} \\
\mathrm{L} 30 \mathrm{HT}^{\mathrm{N}}\end{array}$ & $\begin{array}{l}\mathrm{L} \cdot \mathrm{LOHT} / \\
\mathrm{L} 30^{1 \mathrm{~B}}\end{array}$ & $\begin{array}{l}(+) \\
(-) \\
()^{\prime \prime}\end{array}$ \\
\hline BNGL 252 & 4.05 & $\mathrm{~N}$ & $\mathrm{~N}$ & $\mathbf{N}$ & $(-)$ & BNGL 386 & 5.09 & $\mathrm{~s}$ & $\mathrm{~s}$ & $\mathrm{~N}$ & $(+)$ \\
\hline MTTGB02 & $4.06-4.07$ & S & $\mathrm{s}$ & $\bar{N}$ & $(+)$ & PHI 075 & 6.00 & $\mathbf{S}$ & $\mathrm{S}$ & $\mathrm{N}$ & $(+)$ \\
\hline PHI 092 & 4.08 & $\mathrm{~N}$ & $\mathrm{~N}$ & $\bar{N}$ & $(-)$ & $B N G L 238$ & 6.01 & $S$ & $\mathrm{~s}$ & $\mathrm{~N}$ & $(+)$ \\
\hline $\begin{array}{c}M A G T 0 I \\
H 07\end{array}$ & 4.08 & $\mathrm{~N}$ & $\bar{N}$ & $\bar{N}$ & $(-)$ & PHI 077 & 6.01 & $S$ & $S$ & $\bar{N}$ & $(+)$ \\
\hline$B N G L 292$ & $4.09 / 9.06$ & $\mathrm{~N}$ & $\mathrm{~N}$ & $\mathrm{~N}$ & $(-)$ & $B N G L 107$ & 6.01 & $\mathbf{N}$ & $\mathbf{N}$ & $\mathrm{N}$ & $(-)$ \\
\hline PHI 006 & 4.10 & $\mathrm{~S}$ & $\mathrm{~s}$ & $\mathrm{~N}$ & $(+)$ & $B N G L 480$ & 6.04 & $\mathrm{~N}$ & $\mathrm{~N}$ & $\bar{N}$ & $(-)$ \\
\hline$B N G L 589$ & 4.10 & $S$ & $S$ & $\bar{N}$ & $(+)$ & NCOI2 & 6.05 & $\bar{N}$ & $\bar{N}$ & $\bar{N}$ & $(-)$ \\
\hline PHI 024 & 5.00 & $\mathrm{~N}$ & $\bar{N}$ & $\mathrm{~N}$ & $(-)$ & PHI 078 & 6.05 & $\mathrm{~N}$ & $\mathrm{~N}$ & $\mathrm{~N}$ & $(-)$ \\
\hline NC007 & 5.00 & $\bar{N}$ & $\mathrm{~N}$ & $\bar{N}$ & $(-)$ & PHI 08I & 6.05 & $\mathrm{~N}$ & $\bar{N}$ & $\mathrm{~N}$ & $(-)$ \\
\hline $\begin{array}{c}\text { MACEOO } \\
B 03 \\
\end{array}$ & 5.01 & $\mathrm{~S}$ & $\mathrm{~S}$ & $\mathrm{~N}$ & $(+)$ & $B N G L 345$ & 6.05 & $S$ & $S$ & $\overline{\mathrm{N}}$ & $(+)$ \\
\hline$B N G L 143$ & $5.0 \mathrm{I}$ & $S$ & $S$ & $\overline{\mathrm{N}}$ & $(+)$ & $\begin{array}{c}\text { MACT02 } \\
\text { EOI }\end{array}$ & 6.06 & 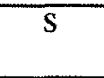 & $\bar{N}$ & s & $(*)$ \\
\hline PHIII3 & 5.02 & $\mathrm{~S}$ & $\mathrm{~N}$ & $\mathrm{~S}$ & $(*)$ & PHI 070 & 6.07 & $\mathrm{~N}$ & $N$ & $\mathrm{~N}$ & $(-)$ \\
\hline$B N G L 105$ & 5.03 & $\mathrm{~N}$ & $\bar{N}$ & $\mathrm{~N}$ & $(-)$ & PHIOS7 & 7.01 & $\mathrm{~s}$ & $\mathrm{~s}$ & $\mathrm{~N}$ & $(+)$ \\
\hline$B N G L 557$ & 5.03 & $\mathrm{~N}$ & $\bar{N}$ & $\overline{\mathrm{N}}$ & $(-)$ & PHI 034 & 7.01 & $\bar{S}$ & $S$ & $\bar{N}$ & $(+)$ \\
\hline PHI 008 & 5.03 & $\bar{N}$ & $\mathrm{~N}$ & $\mathrm{~N}$ & $(-)$ & $B N G L 398$ & 7.02 & $S$ & $S$ & $\bar{N}$ & $(+)$ \\
\hline$B N G L 150$ & $5.03-5.04$ & $\mathrm{~S}$ & $S$ & $\mathrm{~N}$ & $(+)$ & $B N G L 434$ & 7.03 & $\mathrm{~s}$ & $S$ & $\mathrm{~N}$ & $(+)$ \\
\hline$B N G L 603$ & 5.04 & $\mathrm{~N}$ & $\bar{N}$ & $\bar{N}$ & $(-)$ & $B N G L 155$ & 7.03 & $\bar{S}$ & S & $\bar{N}$ & $(+)$ \\
\hline$B N G L 653$ & 5.04 & $\mathrm{~N}$ & $\bar{N}$ & $\mathrm{~N}$ & $(-)$ & BNGL339 & $7.03-7.06$ & $S$ & S & $\mathrm{N}$ & $(+)$ \\
\hline $\begin{array}{c}\text { MACEOI } \\
A 03 \\
\end{array}$ & 5.04 & $s$ & $\mathrm{~N}$ & $\mathbf{N}$ & $\left(^{*}\right)$ & $\begin{array}{c}\text { MACEOI } \\
\text { GOI }\end{array}$ & $7.03-7.04$ & $\bar{s}$ & $\mathrm{~s}$ & $\bar{N}$ & $(+)$ \\
\hline$B N G L 278$ & 5.06 & $s$ & $\mathrm{~s}$ & $\mathrm{~N}$ & $(+)$ & BNGL 469 & $\begin{array}{c}2.02 / 7.05 \\
9.03 \\
\end{array}$ & $\mathrm{~S}$ & $\mathrm{~s}$ & $\mathrm{~N}$ & $(+)$ \\
\hline$B N G L 609$ & 5.06 & $\bar{S}$ & $S$ & $\mathbf{N}$ & $(+)$ & $\begin{array}{c}\text { MACEOI } \\
F 07 \\
\end{array}$ & 7.05 & $\bar{s}$ & $\mathrm{~s}$ & $\mathrm{~N}$ & $(+)$ \\
\hline PHI 085 & 5.07 & $S$ & $\mathrm{~S}$ & $\mathrm{~N}$ & $(+)$ & $B N G L 572$ & $7.04-7.06$ & $\mathrm{~N}$ & $\mathrm{~N}$ & $\mathrm{~N}$ & $(-)$ \\
\hline$B N G L 118$ & 5.08 & s & $s$ & $\mathrm{~N}$ & $(+)$ & PHI 082 & 7.06 & $\mathrm{~s}$ & $\mathrm{~s}$ & $\mathrm{~N}$ & $(+)$ \\
\hline$B N G L 389$ & 5.09 & $\mathrm{~s}$ & $\mathrm{~s}$ & $\mathrm{~N}$ & $(+)$ & $\begin{array}{c}\text { MACEOI } \\
C 08 \\
\end{array}$ & 8.02 & $N$ & $\mathrm{~N}$ & $\mathbf{N}$ & $(-)$ \\
\hline
\end{tabular}

${ }^{\text {Ap }}$ Posição dos locos SSRs disponiveis em hittp:llwww. agron.missouriedu; ${ }^{18}(\mathrm{~N})$ : ausência de contrate alélico no loco marcador; (S) : presença de contraste alélico; ${ }^{C}(\cdot):$ loco marcador nảo informativo (ausência de contraste alélico entre L10HtHt L30htht); $(+)$ : provável independência entre loco marcador e gene alvo (contrate alélico entre L10HtHtl 30 htht e igualdade alélica L30HtHt/L30htht); (*) : possivel ligação entre loco marcador e gene alvo (presença de contraste alélico entre L1OHtHtL3Ohtht e igualdade alélica entre L10HtHt/L3OHtHt). 
(continuação da Tabela 4)

\begin{tabular}{|c|c|c|c|c|c|c|c|c|c|c|c|}
\hline LOCO SSR & 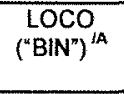 & $\begin{array}{c}\mathrm{L} 10 \mathrm{HT} / \\
\mathrm{L}^{\prime \prime} 0^{\mathrm{B}}\end{array}$ & $\begin{array}{l}\text { L1OHT/ } \\
\text { L3OHT }^{1 \mathrm{~B}}\end{array}$ & $\begin{array}{c}\mathrm{L} 30 \mathrm{HTI} \\
\mathrm{L}^{\prime} 0^{\prime \mathrm{B}}\end{array}$ & $\begin{array}{l}+) \\
(*) \\
\left({ }^{*}\right)^{\prime c \mathrm{ce}}\end{array}$ & LOCO SSP & $\begin{array}{c}\text { LOCO } \\
\left({ }^{\prime} B N^{*}\right)^{1 A}\end{array}$ & $\begin{array}{c}\mathrm{L} 10 \mathrm{HT} / \\
\mathrm{L}^{\prime 8} \mathrm{O}^{\mathrm{B}}\end{array}$ & $\begin{array}{l}\mathrm{L} 10 \mathrm{HT} / \\
\mathrm{L}^{3} \mathrm{OHT}\end{array}$ & $\begin{array}{c}\mathrm{L} 30 \mathrm{HT} / \\
\mathrm{L}^{2} 0^{\prime \mathrm{B}}\end{array}$ & $\begin{array}{l}(+) \\
(-) \\
\left.()^{\prime}\right)^{c}\end{array}$ \\
\hline$B N G L 669$ & 8.03 & $\bar{N}$ & $\overline{\mathrm{N}}$ & $\overline{\mathrm{N}}$ & $(-)$ & $\begin{array}{c}\text { MAGTOI } \\
D 06\end{array}$ & $9.06-9.07$ & $\bar{N}$ & $\mathbf{N}$ & $N$ & $(-)$ \\
\hline$B N G L 119$ & 8.04 & $\bar{N}$ & $\mathrm{~N}$ & $\mathrm{~N}$ & $(-)$ & $B N G L I 28$ & 9.07 & S & $\bar{S}$ & $\mathrm{~N}$ & $(+)$ \\
\hline PHI 060 & 8.04 & $\mathrm{~N}$ & $\mathrm{~N}$ & $\mathrm{~N}$ & $(-)$ & PHI 059 & 10.02 & $\overline{\mathrm{N}}$ & $\mathbf{N}$ & $\bar{N}$ & $(-)$ \\
\hline PHI 115 & 8.04 & $\overline{\mathrm{N}}$ & $\bar{N}$ & $\bar{N}$ & $(-)$ & PHI 063 & 10.02 & $\mathrm{~N}$ & $\bar{N}$ & $\overline{\mathrm{N}}$ & $(-)$ \\
\hline PHI0I4 & 8.04 & $\mathrm{~N}$ & $\mathrm{~N}$ & $\overline{\mathrm{N}}$ & $(-)$ & $B N G L 210$ & 10.03 & $\mathrm{~N}$ & $\mathrm{~N}$ & $\mathrm{~N}$ & $(-)$ \\
\hline$B N G L l 62$ & 8.05 & $\mathrm{~N}$ & $\mathrm{~N}$ & $\overline{\mathrm{N}}$ & $(-)$ & PHI 062 & 10.04 & $\mathrm{~N}$ & $\mathrm{~N}$ & $\bar{N}$ & $(-)$ \\
\hline$B N G L 166^{*}$ & $2.04 / 8.05$ & $\mathrm{~S}$ & $\mathrm{~S}$ & $\mathrm{~N}$ & $(+)$ & PHI 07I & 10.04 & $\bar{S}$ & $S$ & $\bar{N}$ & $(+)$ \\
\hline$B N G L 240$ & 8.06 & $\mathrm{~N}$ & $\mathbf{N}$ & $\mathrm{N}$ & $(-)$ & PHI 084 & 10.04 & S & $S$ & $\mathrm{~N}$ & $(+)$ \\
\hline PHI0I5 & 8.08 & $\bar{S}$ & $\bar{S}$ & $\bar{N}$ & $(+)$ & $B N G L 640$ & 10.04 & $\bar{S}$ & $\bar{S}$ & $\bar{N}$ & $(+)$ \\
\hline $\begin{array}{c}M A C E O I \\
\text { COI }\end{array}$ & 8.08 & S & $S$ & $\bar{N}$ & $(+)$ & $B N G L 137$ & 10.05 & $\mathrm{~N}$ & $\bar{N}$ & $\bar{N}$ & $(-)$ \\
\hline BNGL469 & $\begin{array}{c}9.03 / 2.02 \\
7.05\end{array}$ & $\mathrm{~S}$ & $S$ & $\mathrm{~N}$ & $(+)$ & $B N G L 153$ & 10.06 & $S$ & $\bar{S}$ & $\bar{N}$ & $(+)$ \\
\hline $\begin{array}{c}\text { MACT02 } \\
\text { B08 }\end{array}$ & $9.01-9.02$ & $S$ & $\mathrm{~S}$ & $N$ & $(+)$ & $B N G L 236$ & 10.06 & $\mathrm{~N}$ & $\mathrm{~N}$ & $\mathrm{~N}$ & $(-)$ \\
\hline PHI033 & 9.01 & $\mathrm{~S}$ & $\mathrm{~S}$ & $\mathrm{~N}$ & $(+)$ & $B N G L 594$ & 10.06 & $\mathrm{~N}$ & $\mathbf{N}$ & $\bar{N}$ & $(-)$ \\
\hline$B N G L 244$ & 9.02 & $S$ & $\mathrm{~S}$ & $\bar{N}$ & $(+)$ & $B N G L 279$ & 10.07 & $\bar{S}$ & $\bar{S}$ & $\overline{\mathrm{N}}$ & $(+)$ \\
\hline PHI 065 & 9.03 & $\mathrm{~S}$ & $S$ & $\bar{N}$ & $(+)$ & $\begin{array}{c}\text { MACT02 } \\
\text { B10 }\end{array}$ & & S & S & $\bar{N}$ & $(+)$ \\
\hline$B N G L 127$ & 9.04 & $\bar{S}$ & $\bar{S}$ & $\mathrm{~N}$ & $(+)$ & $M A G B 01$ & & $\bar{N}$ & $\bar{N}$ & $\overline{\mathrm{N}}$ & $(-)$ \\
\hline$B N G L 430$ & 9.04 & $\bar{S}$ & $\mathrm{~S}$ & $\mathrm{~N}$ & $(+)$ & $\begin{array}{c}\text { MAGI } \\
\text { COS }\end{array}$ & & $\mathrm{S}$ & $S$ & $\mathrm{~N}$ & $(+)$ \\
\hline$B N G L 292$ & $4.09 / 9.06$ & $\mathbf{N}$ & $\mathrm{N}$ & $\mathrm{N}$ & $(-)$ & & & & & & \\
\hline
\end{tabular}

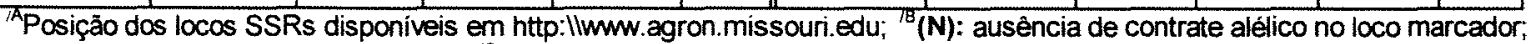
(S) : presença de contraste alélico; ${ }^{1 C}(-)$ : loco marcador nāo informativo (ausência de contraste alélico entre L10HtHt /L30htht); (+): provável independéncia entre loco marcador e gene alvo (contrate alélico entre L10HtHth.30htht e igualdade alélica L3OHtHtL $30 h t h t) ;()^{*}$ : possivel ligação entre loco marcador e gene alvo (presença de contraste alélico entre L10HtHtL3Ohtht e igualdade alélica entre L10HtHt/L3OHtHt).

ao gene introgredido.

Para esses casos informativos ("+" $e$ "*”, Tabela 4), espera-se que ocorram duas situações, a saber: igualdade alélica entre o parental recorrente (L30htht) e a linhagem convertida ( $\mathrm{L} 30 \mathrm{HtHt})$, simultaneamente ao contraste alélico entre L30htht/L30HtHt e o parental doador ( $\mathrm{L} 10 \mathrm{HtHt})$ ou igualdade alélica entre o parental doador $(\mathrm{L} 10 \mathrm{HtH}$ ) e a linhagem convertida (L3OHtHt), 
paralelamente ao contraste alélico entre L10HtHt/L30HtHt e L30htht. O primeiro caso seria uma indicação da independência do loco marcador em relação ao gene marcador convencional $(H t)$ e o segundo indicaria a possibilidade de ligação desses locos marcadores a esse gene introgredido em L30HtHt.

Dentre os 61 marcadores informativos, 56 (símbolo "+", Tabela 4) apresentaram um padrão de bandeamento igual ao da primeira situação. Isso sugere que, nestes locos, a linhagem isogênica convertida recuperou os alelos marcadores derivados do parental recorrente durante as seis gerações de retrocruzamentos e, conseqüentemente, é de se esperar ausência de ligação entre estes marcadores e o gene $H t$ introgredido. Por outro lado, os cinco marcadores restantes mostraram evidências de ligação, uma vez que nestes casos o alelo marcador derivado do parental doador mostrou-se presente na linhagem convertida (Figura 4).

A identificação de cinco locos marcadores putativamente ligados ao gene $H t$ introgredido, dentre os 61 casos PR / LQI/PD informativos, permitiu estimar que $8,20 \%$ do genoma do parental doador ficou retido na linhagem convertida L30HtHt. Similarmente ao observado, cinco locos marcadores $\left\{61 \times\left[u_{T}+\left(V_{T}\right)^{1 / 2}\right]=61 \times 0,0767=4,67\right\}$ seria a quantidade máxima esperada a ficar retida em uma linhagem convertida $R_{6} F_{3}\left(R C_{6} S_{1}\right)$, assumindo a introgressão do gene $H t$ em L30 por seis ciclos de retrocruzamentos sem seleção fenotípica para o fenótipo do parental recorrente, uma distância genética média de 1,61 M para cada um dos 10 cromossomos de milho (Davis et al., 1996) e um gene de resistência supostamente introgredido na região central do cromossomo da linhagem convertida $\mathrm{L} 30 \mathrm{HtH} t\left(\mathrm{RC}_{6} \mathrm{~S}_{1}\right)$. Em termos de distância genética, essa fração corresponderia a $39,79 \mathrm{cM}\left(100 \times 16,1 \times u_{T}\right)$.

Os programas de melhoramento via sucessivos retrocruzamentos comumente efetuam a seleção do gene alvo simultaneamente a seleção fenotípica para o tipo do parental recorrente, com a finalidade de recuperar o 


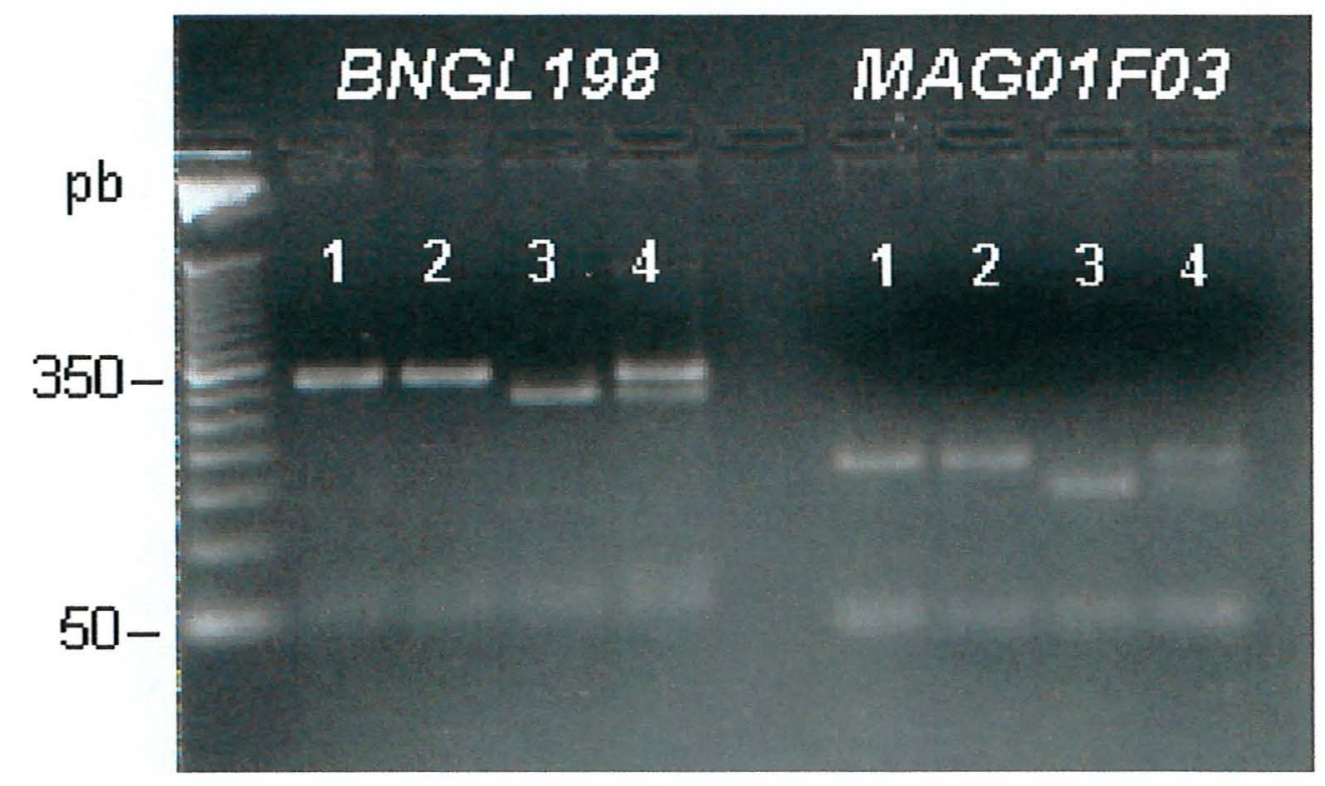

Figura 4 - "Primers" que amplificam regiões de microssatélites em (1): parental doador L10HtHt (PD), (2): linhagem convertida L30HtHt (LQI), (3): parental recorrente L30htht (PR) e (4): híbrido L30Htht, indicando contrastes alélicos entre L10HtHt/L30htht e L30htht/L30HtHt e igualdades alélicas entre $\mathrm{L} 10 \mathrm{HtH} / \mathrm{L} 30 \mathrm{HtH}$, para os locos marcadores BNGL198 e MAG01F03. 
genótipo desejável em menos gerações. Portanto, a percentagem observada de $8,20 \%$ do genoma do doador $(\mathrm{L} 10 \mathrm{HH})$ retida em $\mathrm{L} 30 \mathrm{HtH}$ foi inesperadamente próxima ao limite superior esperado de 7,66\% \{100 $\times\left[u_{\mathrm{T}}+\right.$ $\left(V_{T}\right)^{1 / 2}=2,47+5,19 \%$, calculado com base em Muehlbauer et al.(1988), já que, neste último caso, os autores assumem ausência de seleção para o tipo do parental recorrente. Uma das razões para essa diferença pode ser atribuída a cobertura insuficiente do genoma obtida com a quantidade de marcadores informativos utilizada no presente trabalho.

Desses cinco locos putativamente ligados ao gene de resistência, dois estão posicionados no cromossomo 2, dentro do "bin" 2.08 (BNGL198 e MAG01F03), outros dois (PHI113 e MACE01A03) no cromossomo 5 dentro dos "bins" 5.02 e 5.04, respectivamente, e um (MACTO2E01) no "bin 6.06" do cromossomo 6 (Figura 5). Alguns cálculos teóricos efetuados com base nas fórmulas aplicadas por Muehlbauer et al. (1988) permitiram estimar que a percentagem média esperada do genoma de L10HtHt retida no bloco de ligação próximo ao gene introgredido em L30HtHt seria de $17,68 \pm 12,29 \%$ $\left\{100 \times\left[u_{M} \pm\left(V_{u_{M}}^{1 / 2}\right)\right]\right\}$, o que corresponderia de 1 até $3[61 \times 0,076 \times$ $(28,4694 / 39,7897)]$ marcadores efetivamente ligados ao gene $H t$, dentre os cinco candidatos a ligação. Em termos de distância genética, essa proporção corresponderia a $28,47 \pm 19,79 \mathrm{cM}[161 \times(0,1768 \pm 0,1229)]$, assumindo que a introgressão do gene $H t$ em L30 tenha sido efetuada naquelas condições já descritas acima. Os demais $132,53 \mathrm{cM}(132,53+28,47=161 \mathrm{cM})$ corresponderiam a proporção esperada do cromossomo portador do gene alvo (cromossomo marcador) que teria recuperado o genoma do parental recorrente.

O restante da fração genômica do parental doador que fica retida em qualquer outro cromossomo individual não marcador de L30HtHt seria da ordem de $0,78 \pm 3,63 \%\left\{100 \times\left[u_{N} \pm\left(V_{N}\right)^{1 / 2}\right]\right\}$ e para todos os 9 cromossomos não marcadores, a percentagem total esperada passaria para 7,03 \% [100 x $9 \times$ 


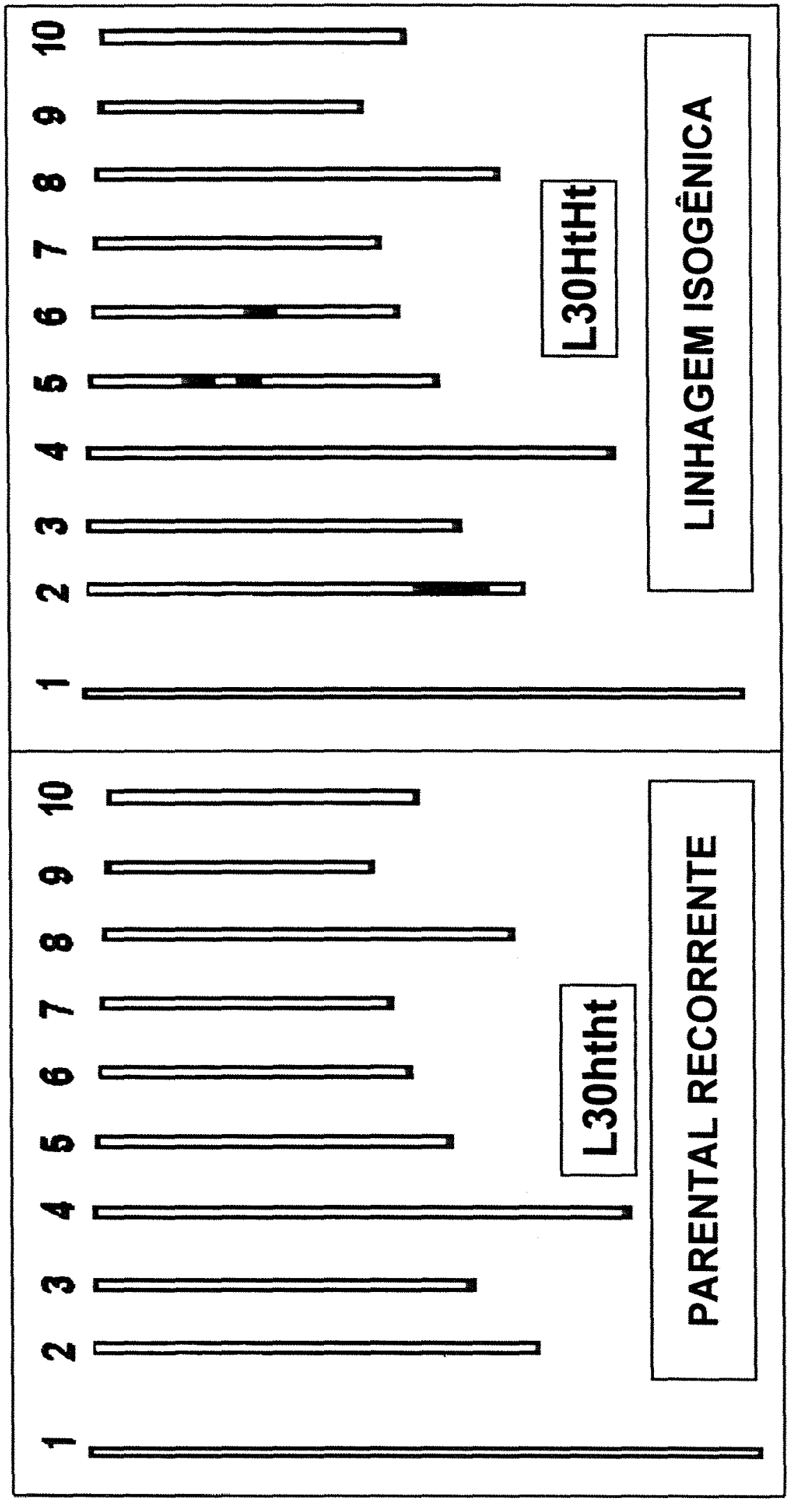

踦

兄苞

与离

통응 응

흥ㅇㅁ음

엄응 음

d.으

총용

홍 응

응 응

엉

宁 층

E

可

됴요

응

(1) 要

๙ั

뭄

흥

ड

京

可 홍

a

离㐫

엉 \&

Ð 证

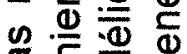

ชั

긍

응 호

喝至

을 일

適宫

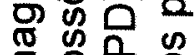

돋유

동

䗆全要

중 is응

온 뭉

동 홍음

동융

品 必 응 I

in

뜸 
$\left.\left(u_{N}\right)\right]$. Em termos de distância no mapa, um total de 1,26 $\pm 5,85 \mathrm{cM}\left\{100 \times\left[u_{N}\right.\right.$ $\left.\left.\pm\left(V_{N}\right)^{1 / 2}\right] \times 1,61\right\}$ corresponderia a fração esperada derivada do parental doador presente em qualquer cromossomo individual não marcador ou 11,32 cM [100 $\left.\left.\times 9 \times\left(u_{N}\right)\right] \times 1,61\right\}$, se fossem incluídos todos os nove cromossomos não portadores do gene $H t$ (cromossomos não marcadores).

A partir desses dados, supōe-se que dos $39,79 \mathrm{cM}$ retidos em $\mathrm{L} 30$, cerca de $2 / 3 \quad(28,47 / 39,79)$ estejam localizados no bloco de ligação próximo ao gene marcador e apenas $1 / 3(11,32 / 39,79)$ em qualquer um dos cromossomos não marcadores. Essa última fração corresponderia aqueles marcadores informativos designados falsos positivos $\left[\mathrm{P}^{+}=100 \times(0,1132 / 0,3979)=28,45 \%\right]$ que, apesar de não estarem ligados ao gene alvo, revelam monomorfismos entre o parental doador ( $\mathrm{L} 1 \mathrm{OH} t \mathrm{Ht}$ ) e a linhagem convertida ( $\mathrm{L} 30 \mathrm{HtH})$. Contudo, essa proporção $\left(\mathrm{P}^{+}\right)$tende a decrescer tanto com o aumento das gerações de retrocruzamentos, bem como com a diminuição do número de cromossomos da espécie estudada (Muehlbauer et al., 1988).

Uma explicação para essa possivel fonte de erro (falsos positivos) decorre das diferenças entre o parental recorrente e a linhagem convertida não restringirem-se apenas ao segmento cromossômico portador do gene alvo, mas também a outras seqüências de DNA derivadas do parental doador retidas em outras regiões do genoma (Young \& Tanksley, 1989; Tingey \& Tufo, 1993). Uma segunda razão seria conseqüência da retenção de extensas regiões de DNA associadas a região selecionada ("linkage drag"), durante os sucessivos retrocruzamentos. Apesar dessa última situação revelar uma condição de ligação entre marcador e gene alvo, o resultado genético da segregação entre esses dois pontos seria similar ao de dois locos segregando independentemente. Marcadores ligados nessas condições seriam impróprios para orientar a seleção de genes de resistência.

Análises genéticas de linhagens isogênicas com marcadores moleculares têm mostrado que o conceito de linhagens isogênicas pode ser 
ampliado em relação a definição original dada inicialmente por Borlaug \& Gilber (1953). Portanto, ao invés de defini-las como um conjunto de linhagens cujos genótipos são contrastantes entre si apenas para um ou poucos genes controladores de um único carácter, cabe adicionar que esses contrastes também ocorrem em uma ou poucas regiões genômicas distribuídas casualmente pelo genoma, além da região que contém o gene de interesse. Esse novo conceito seria mais amplo, pois admite que as diferenças entre as isolinhas pode incluir múltiplos genes em cada uma das regiões genômicas do parental doador retida na linhagem convertida e, concomitantemente, tais diferenças não seriam restritas a um único caráter. Mesmo porquê, teoricamente, a completa eliminação dos alelos derivados do parental doador para os locos não ligados ao gene introgredido nunca deve ocorrer (Melchinger, 1990) se for considerada que tal eliminação apresenta uma tendência geométrica durante os sucessivos retrocruzamentos .

Outra fonte de erro ( $P^{-}$: falsos negativos) intrínseca à análise de LQIs ocorre ao se aceitar que alelos marcadores derivados do parental doador ausentes na linhagem convertida $\mathrm{RC}_{6} \mathrm{~S}_{1}(\mathrm{~L} 30 H \mathrm{H} H t)$ sejam uma indicão da não ligação dos locos marcadores correspondentes ao gene introgredido. Em outras palavras, tais locos corresponderiam aqueles marcadores informativos que são monomórficos entre as linhagens recorrente (L30htht) e convertida $(\mathrm{L} 30 H t H t)$, apesar de estarem ligados ao gene de interesse. Com base na proposta de cálculo de Muehlbauer et al. (1988) aplicada a situação presente, a probabilidade de ocorrência de falsos negativos seria da ordem de $8,44 \%$ $\left\{\left[\mathrm{P}^{-}=161 \times(1-0,1768)\right] /[16,10 \times(1-0,0247)]\right\}$, o que corresponderia a cerca de $1 / 3$ da probabilidade de ocorrência estimada de falsos positivos $\left(P^{+}=28,45\right.$ $\%)$.

A falta de disponibilidade desses materiais genéticos altamente especializados (LQIs) para a maioria das regiões do genoma de interesse potencial é outra limitação ao emprego rotineiro da estratégia de análise de 
LQIs (Giovannoni et al., 1991). Ainda que a obtenção de linhagens isogênicas seja possível, muitas vezes o processo acaba sendo demorado e custoso devido ao tempo requerido para a recuperação dos genes desejáveis do parental recorrente. No presente estudo, essa limitação foi irrelevante, uma vez que a obtenção de tais genótipos fizeram parte da programação habitual da empresa colaboradora (Sementes Agroceres S/A). Uma análise prévia via LQIs foi vantajosa nesse caso, pois reduziu significativamente a quantidade de locos marcadores destinados ao mapeamento do gene $\mathrm{Ht}$. Adicionalmente, a genotipagem efetuada com os 125 marcadores envolveu um reduzido número de amostras (parental doador, parental recorrente e linhagem convertida) que ainda resultou na identificação de apenas cinco marcadores microssatélites canditatos a ligação. A partir disso, entendeu-se a validade de se gerar uma população segregante destinada ao mapeamento do gene $\mathrm{Ht}$ mediante marcadores microssatélites.

Contudo, para que a técnica de mapeamento de genes via LQIs possa ser eficientemente utilizada, deve ser observada a existência de uma quantidade substancial de contrastes alélicos entre L30htht/L10HtHt. Supõe-se que a percentagem aproximada de $50 \%$ de diversidade detectada entre os parentais doador e recorrente [100 x (61/125)], revelada pela detecção dos 61 marcadores informativos, tenha sido suficiente para viabilizar o uso de marcadores microssatélites na presente análise genética. A validade dessa afirmação deve-se a existência de uma evidente correspondência entre os valores esperados e observados quanto a quantidade de marcadores derivados do parental doador retida na linhagem convertida, bem como quanto a quantidade situada próxima ao gene introgredido (representada por BNGL198 e MAG01F03, conforme evidências obtidas nas seções 4.4 e 4.5 ).

\subsection{Seleção de isolados e fenotipagem de segregantes $R C_{1} F_{1}$}


A seleção do isolado utilizado na seção 4.4 foi efetuada com base nos resultados da Tabela 5 , a qual revela a reação das linhagens L40htht, L30htht, L30HtHt e dos hibridos (L30HtHt x L40htht) e (L30htht $\times$ L40htht) frente a cinco isolados coletados em diferentes regiões do Pais. Os referidos genótipos foram agrupados como resistentes $(R)$ e suscetiveis $(S)$ para plantas classificadas como $R_{1} / R_{2} / R_{3} / R_{4}$ e $S_{5} / S_{6}$, respectivamente, segundo o tipo de lesão descrito em Esteves (1989).

Tabela 5 - Reação das linhagens L30HtHt, L30htht, L30Htht e L40htht e dos híbridos $F_{1} H$ tht ${ }^{\prime A}$ e $F_{1} h t^{\prime} t^{B}$ frente a cinco isolados de $E$. turcicum, coletados nas Regiões Sul, Sudoeste e Centro-Oeste.

\begin{tabular}{lccccc}
\hline \multirow{2}{*}{ Genótipos } & \multicolumn{5}{c}{ Isolados } \\
\cline { 2 - 6 } L30HtHt & 18 & 47 & 48 & 49 & 53 \\
L30hth & $\mathrm{R}$ & $\mathrm{R}$ & $\mathrm{si}$ & $\mathrm{R}$ & $\mathrm{si}$ \\
L30Htht & $\mathrm{R}$ & $\mathrm{S}$ & $\mathrm{si}$ & $\mathrm{S}$ & $\mathrm{si}$ \\
L40htht & $\mathrm{R}$ & $\mathrm{R}$ & $\mathrm{si}$ & $\mathrm{R}$ & $\mathrm{si}$ \\
& $\mathrm{R}$ & $\mathrm{R}$ & $\mathrm{si}$ & $\mathrm{S}$ & $\mathrm{si}$ \\
F $_{1}$ Htht $^{\text {/A }}$ & $\mathrm{R}$ & $\mathrm{R}$ & $\mathrm{R}$ & $\mathrm{R}$ & $\mathrm{R}$ \\
F $_{1}$ htht $^{\text {BB }}$ & $\mathrm{R}$ & $\mathrm{S}$ & $\mathrm{R}$ & $\mathrm{S}$ & $\mathrm{S}$
\end{tabular}

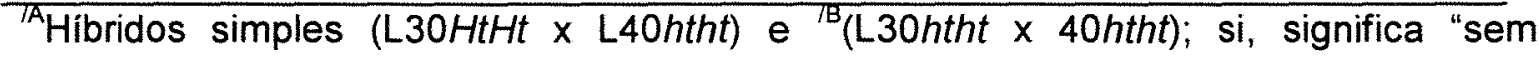
informação". Plantas resistentes $(R)$ com reações $R_{1}, R_{2}, R_{3}, R_{4}$ e plantas suscetiveis (S) com reações $S_{5}$ e $S_{6}$, segundo escala descritiva em Esteves (1989).

Isolados avirulentos para o gene introgredido em $\mathrm{L} 30 \mathrm{HtHt}$, porém virulentos para todos os genes qualitativos presentes em L30htht e nos indivíduos suscetíveis $\mathrm{RC}_{1} \mathrm{~F}_{1}$ (32 indivíduos, Tabela 6), foram considerados candidatos potenciais para a discriminação da presença de $H t$ nos segregantes derivados de $[(\mathrm{L} 30 H$ tHt $\times$ L40htht $) \times$ L40htht], independente da reação mani- 
Tabela 6 - Expressão da resistência de 138 indivíduos da população [( $230 H t H t$ $\times$ L40htht) $\times$ L40htht], frente ao isolado 47 de E. turcicum.

\begin{tabular}{|c|c|c|c|c|c|c|c|c|c|c|c|}
\hline $\begin{array}{l}\begin{array}{l}\text { Genó- } \\
\text { tipos }^{\prime B}\end{array} \\
\end{array}$ & $\bar{A}$ & $\begin{array}{l}\text { Genó- } \\
\text { tipos }^{\text {'B }}\end{array}$ & TA & $\begin{array}{l}\text { Genó- } \\
\text { tipos }^{\prime B}\end{array}$ & DA & $\begin{array}{l}\text { Genó- } \\
\text { tipos }^{1 B}\end{array}$ & $T_{A}$ & $\begin{array}{l}\text { Genó- } \\
\text { tipos }\end{array}$ & TA & $\begin{array}{l}\text { Genó- } \\
\text { tipos }^{\prime B} \\
\end{array}$ & $\mathrm{TA}$ \\
\hline $1^{T C}$ & $R_{1}$ & 25 & $R_{3}$ & 48 & $\mathrm{R}_{1}$ & 70 & $\mathrm{R}_{3}$ & 93 & $\mathrm{R}_{3}$ & 116 & $S_{5}$ \\
\hline 2 & $\mathrm{R}_{1}$ & 26 & $\mathrm{R}_{3}$ & 49 & $\mathrm{R}_{3}$ & $71 a$ & $\mathrm{R}_{3}$ & 94 & $\mathrm{R}_{3}$ & 117 & $R_{3}$ \\
\hline 3 & $\mathrm{R}_{3}$ & 27 & $\mathrm{~S}_{5}$ & 50 & $S_{5}$ & $71 b$ & $\mathrm{R}_{3}$ & 95 & $R_{3}$ & 118 & $S_{5}$ \\
\hline 4 & $S_{5}$ & 28 & $S_{5}$ & 51 & $\overline{R_{3}}$ & 72 & $\mathrm{R}_{3}$ & 96 & $\mathrm{R}_{3}$ & 119 & $S_{5}$ \\
\hline 5 & $\mathrm{R}_{3}$ & 29 & $R_{1}$ & 52 & $R_{3}$ & 73 & $\mathrm{~S}_{5}$ & 97 & $\mathrm{R}_{3}$ & 120 & $R_{3}$ \\
\hline 6 & $S_{5}$ & 30 & $\mathrm{~S}_{5}$ & 53 & $S_{5}$ & 74 & $\mathrm{R}_{3}$ & 98 & $\mathrm{R}_{3}$ & 121 & $\mathrm{R}_{1}$ \\
\hline 7 & $R_{1}$ & 31 & $\mathrm{R}_{1}$ & 54 & $R_{3}$ & 75 & $R_{2}$ & 99 & $\mathrm{R}_{3}$ & 122 & $\mathrm{R}_{3}$ \\
\hline 8 & $R_{1}$ & 32 & $\mathrm{R}_{1}$ & 55 & $S_{5}$ & 76 & $\mathrm{~S}_{5}$ & 100 & $\mathrm{R}_{2}$ & 123 & $\mathrm{R}_{3}$ \\
\hline 9 & $\mathrm{R}_{3}$ & 33 & $\mathrm{R}_{3}$ & $56^{a}$ & $\mathrm{R}_{1}$ & 77 & $\mathrm{R}_{1}$ & 101 & $\mathrm{R}_{3}$ & 124 & $R_{3}$ \\
\hline 10 & $R_{2}$ & 34 & $\mathrm{R}_{3}$ & $56 b$ & $\mathrm{~S}_{5}$ & 78 & $\mathrm{R}_{3}$ & 102 & $\mathrm{R}_{1}$ & 125 & $R_{3}$ \\
\hline 11 & $\mathrm{R}_{2}$ & 35 & $\mathrm{R}_{1}$ & 57 & $\mathrm{~S}_{5}$ & 79 & $R_{1}$ & 103 & $S_{5}$ & 126 & $\mathrm{R}_{3}$ \\
\hline 12 & $\mathrm{R}_{3}$ & 36 & $\mathrm{R}_{3}$ & 58 & $\mathrm{R}_{1}$ & 80 & $\mathrm{R}_{3}$ & 104 & $\mathrm{~S}_{5}$ & 127 & $R_{4}$ \\
\hline 13 & $R_{1}$ & 37 & $\mathrm{~S}_{5}$ & 59 & $\mathrm{R}_{3}$ & 82 & $R_{3}$ & 105 & $S_{5}$ & 128 & $R_{3}$ \\
\hline 14 & $\mathrm{R}_{4}$ & 38 & $R_{1}$ & 60 & $\mathrm{R}_{3}$ & 83 & $\mathrm{R}_{1}$ & 106 & $R_{3}$ & 129 & $S_{5}$ \\
\hline 15 & $\mathrm{R}_{3}$ & 39 & $R_{1}$ & 61 & $\mathrm{R}_{1}$ & 84 & $R_{1}$ & 107 & $R_{3}$ & 130 & $S_{5}$ \\
\hline 16 & $R_{1}$ & 40 & $\mathrm{~S}_{5}$ & 62 & $\mathrm{R}_{3}$ & 85 & $\mathrm{R}_{3}$ & 108 & $\mathrm{R}_{1}$ & 131 & $\mathrm{R}_{1}$ \\
\hline 17 & $R_{3}$ & 41 & $R_{1}$ & 63 & $R_{1}$ & 86 & $\mathrm{~S}_{5}$ & 109 & $\mathrm{R}_{3}$ & 132 & $\mathrm{R}_{3}$ \\
\hline 18 & $R_{1}$ & 42 & $R_{3}$ & 64 & $R_{3}$ & 87 & $\mathrm{R}_{4}$ & 110 & $R_{1}$ & 133 & $R_{3}$ \\
\hline 19 & $\mathrm{R}_{2}$ & 43 & $\mathrm{R}_{3}$ & 65 & $R_{1}$ & 88 & $\mathrm{~S}_{5}$ & 111 & $\mathrm{R}_{1}$ & 134 & $R_{3}$ \\
\hline 20 & $\mathrm{~S}_{5}$ & 44 & $\mathrm{R}_{3}$ & 66 & $\mathrm{R}_{1}$ & 89 & $\mathrm{R}_{3}$ & 112 & $S_{5}$ & 135 & $S_{5}$ \\
\hline 21 & $R_{1}$ & 45 & $\mathrm{~S}_{5}$ & 67 & $R_{1}$ & 90 & $\mathrm{R}_{4}$ & 113 & $R_{1}$ & 136 & $S_{5}$ \\
\hline 22 & $\mathrm{~S}_{5}$ & 46 & $\mathrm{R}_{1}$ & 68 & $\mathrm{R}_{2}$ & 91 & $\mathrm{R}_{3}$ & 114 & $\mathrm{R}_{3}$ & 137 & $\mathrm{R}_{4}$ \\
\hline 24 & $\mathrm{R}_{3}$ & 47 & $\mathrm{R}_{1}$ & 69 & $\mathrm{~S}_{5}$ & 92 & $S_{5}$ & 115 & $\mathrm{R}_{3}$ & 138 & $\mathrm{R}_{4}$ \\
\hline
\end{tabular}

${ }^{\mathbb{A}}$ expressão fenotípica, segundo Esteves $(1989) ;{ }^{18}$ segregantes $R_{1} F_{1} F_{1}$ da população [(L3OHtHt x L40htht) $\times$ L40htht] 
festada pelo parental L40htht. Apesar dos isolados 47, 49 e 53 estarem dentro dessa categoria, apenas o primeiro foi selecionado para a fenotipagem dos indivíduos $R C_{1} F_{1}$, uma vez que o mesmo apresenta informações a respeito da reação das LQIs, além de permitir a análise de outro(s) gene(s) de resistência presente(s) em L40htht.

A resistência de 138 indivíduos $R C_{1} F_{1}$ da população [(L3OHtHt $x$ L40htht) $\times$ L40htht] (Tabela 6) foi avaliada segundo o tipo de lesão descrito por Esteves (1989). O isolado codificado pelo número 47 permitiu a identificação de 32 segregantes suscetíveis, 36 totalmente resistentes $\left(R_{1}\right)$ e 70 indivíduos com diferentes níveis de resistência intermediária $\left(R_{2}: 6, R_{3}: 58\right.$ e $R_{4}$ :6). A constatação de aproximadamente $1 / 4$ de segregantes $R C_{1} F_{1}$ suscetíveis (32 individuos, Tabela 6), aliada a reação de resistência conferida pelos parentais L30HtHt e L40htht, pela linhagem L30Htht e híbrido (L30HtHt $x$ L40htht), bem como a reação de suscetibilidade apresentada pela linhagem L30htht e híbrido (L30htht $x$ L40htht) (Tabela 5), sugeriu a segregação de dois genes qualitativos, presentes de forma complementar em ambos os parentais e segregando independentemente na geração $\mathrm{RC}_{1} \mathrm{~F}_{1}$. Essa hipótese baseia-se nas seguintes observações (Tabelas 5 e 6), a saber:

- a resistência conferida pelo gene $H t$ introgredido em $\mathrm{L} 30 \mathrm{HtHt}$ frente ao isolado 47 é dominante, uma vez que L30htht foi suscetivel e L30Htht e L30 HtHt foram resistentes (Tabela 5);

- a resistência de $L 40$ frente ao isolado 47 deve ser conseqüência da ação de outro(s) gene(s) diferente(s) do Ht presente em L30HtHt, uma vez que o isolado 49 promove reação de resistência em L30HtHt e suscetibilidade em L30htht / L40, respectivamente (Tabela 5);

- devido ao híbrido (L30htht x L40htht) e à proporção observada de aproximadamente $1 / 4$ de indivíduos $R C_{1} F_{1}$ terem sido suscetíveis, então a resistência de L40htht deve ser atribuída a expressão de um único gene recessivo, de agora em diante designado de $t t e$, assim, a representação 
genotípica de L40 seria L40hthtrtrt (Tabelas 5 e 6).

Possivelmente, ambos os genes ( $H t$ e $r t$ ) ainda sejam influenciados pela presença de múltiplos fatores de efeito "menor", dado os diferentes níveis de resistência detectados no grupo constituído pelos indivíduos intermediários $\left(R_{2}, R_{3}\right.$ e $\left.R_{4}\right)$. Esses resultados estão de acordo com vários trabalhos que preconizam um modelo genético de resistência a helminthosporiose conferido tanto pela herança qualitativa, bem como pela quantitativa (Bentolila et al., 1991; Carson, 1995; Freymark et al., 1993; Helentjaris, 1993 e 1995; McMullen \& Simcox, 1995; Simcox \& Bennetzen, 1993 e Zaitlin et al., 1992).

A hipótese genética referida acima pressupõe que ambos os locos de L30HtHt sejam ocupados pelos alelos $H t$ e Rt na condição homozigota, onde o alelo $H t$ confere resistência ao isolado 47 e $R t$ suscetibilidade. O efeito conjunto de $H t$ e Rt presentes em L30 seria expresso pela reação de resistência e a linhagem convertida, anteriormente designada como $\mathrm{L} 30 \mathrm{HtH}$, passaria a ser reconhecida pela designação de L30HtHtRtRt. Por outro lado, a segregação observada em $\mathrm{RC}_{1} F_{1}$, sugeriu que 0 parental L40htht seria portador de genes contrastantes aos presentes em L30HtHtRtRt para os locos em questão. Nesse caso, a resistência ao isolado 47 seria proveniente da expressão do genótipo homozigoto recessivo $r$ trt. No loco $\mathrm{Ht}$, o genótipo htht expressaria reações do tipo compatível (suscetivel) frente ao mesmo isolado. $O$ efeito conjunto conferido pelo genótipo hipotético de L40htht seria expresso por reações do tipo incompatível (resistência) e, portanto, a linhagem L40htht passaria a ser denominada como L40hthtrtrt.

A partir dessas considerações, seria esperada a geração de quatro genótipos distintos na população obtida a partir de [(L30HtHtRtRt $\times$ L40hthtrtrt) x L40hthtrtrf], representados pelos tipos resistentes HthtRtrt, Hthtrtrt e hthtr trt e suscetivel hthtîrt na proporção $1 / 4: 1 / 4: 1 / 4: 1 / 4$, respectivamente. O teste $X^{2}$ aplicado às proporções esperadas de $3 / 4$ resistentes $\left(R_{1}, R_{2}, R_{3}\right.$ e $\left.R_{4}\right)$ para $1 / 4$ suscetiveis $\left(S_{5}\right)$ não foi significativo, indicando que as diferenças entre as 
proporções esperadas (103,50 resistentes e 34,5 suscetiveis) e as observadas (106 resistente e 32 suscetíveis, Tabela 6 ) não foram suficientes sob o ponto de vista estatístico para justificar a rejeição da hipótese genética acima descrita (Tabela 7).

Apenas um alelo recessivo capaz de conferir resistência a helminthosporiose foi identificado até o momento (Carson, 1995). Entretanto, esse gene, localizado no braço curto do cromossomo 1, próximo ao centrômero, apresenta uma reação frente às raças avirulentas (raças 0, 1, 23 e $23 \mathrm{~N}$ ) muito diferente daquela apresentada por outros genes qualitativos descritos na literatura. A resistência conferida pelos genes $H t_{1}, H t_{2}$ e $H t_{3}$, por exemplo, manifesta-se através de lesões necrótico -cloróticas (Leonard et al., 1989). O gene $H t N$ atua pelo aumento do período entre a infecção e a expressão dos sintomas (Smith \& Kinsey, 1993), pelo atraso no início da esporulação (Simcox \& Bennetzen, 1993) e pela prevenção da formação das lesões necróticas sobre plantas adultas (Gevers, 1975). Já o gene recessivo identificado por Carson (1995), inicialmente manifesta-se pela formação de pontos de infecção pigmentados de laranja escuro a marrom que, mais tarde, ficam envolvidos por halo clorótico circular de cerca de $1 \mathrm{~cm}$. Nesse último caso, algumas poucas lesões podem evoluir para a típica lesão necrótica alongada e elíptica de $E$. turcicum. Devido a similaridade dos sintomas de resistência dos genótipos itrt (L40hthtrtrt) em relação a esses genes dominantes já identificados, é possível que 0 alelo recessivo $r t$ presente em L40hthtrtrt seja um outro gene ou, pelo menos, um alelo diferente daquele identificado por Carson (1995). Contudo, essas questões referentes ao gene $r$, bem como $H t$ poderiam ser respondidas somente após um estudo minucioso da amplitude de resistência à raças-específicas, do mapeamento dos referidos genes mediante técnicas moleculares e, ainda, se necessário, de testes de alelismo e seqüenciamento do DNA. 
Tabela 7 - Segregação de $H t$ e $r t$ quanto ao tipo de lesão sobre plantas de diferentes gerações derivadas do cruzamento de L30HtHt (parental $\left.P_{1}\right) \times$ L40htht (parental $P_{2}$ ), linhagens L30Htht $\left(P_{3}\right)$ e L30htht $\left(P_{4}\right)$ e geração $F_{1}$ resultante do cruzamento de $\left(P_{1}\right)$ e $\left(P_{4}\right)$ com L40htht frente ao isolado 47 . Indivíduos $R_{1}, R_{2}, R_{3}$ e $R_{4}$ foram agrupados dentro da classe dos resistentes $(R)$ e $S_{5}$ e $S_{6}$ dentro da classe dos suscetíveis (S).

\begin{tabular}{|c|c|c|c|c|}
\hline Geração & $\begin{array}{l}\text { Plantas } \\
\text { R/(Total) }\end{array}$ & $\begin{array}{l}\text { Plantas } \\
\text { S/(Total) }\end{array}$ & $\begin{array}{l}\text { Proporção } \\
\text { esperada }\end{array}$ & $\mathrm{X}^{2 / \mathrm{A}}$ \\
\hline L30HtHtRtRt $\left(P_{1}\right)$ & $6 /(6)$ & - & $1 \mathrm{R}: 0 \mathrm{~S}$ & - \\
\hline L40hthtrtrt $\left(\mathrm{P}_{2}\right)$ & $6 /(6)$ & & $1 \mathrm{R}: 0 \mathrm{~S}$ & - \\
\hline $\mathrm{RC}_{1} \mathrm{~F}_{1}{ }^{\mathrm{B}}$ & $106 /(138)$ & $32 /(138)$ & $3 \mathrm{R}: 1 \mathrm{~S}$ & (ns) \\
\hline L3OHtht $\left(\mathrm{P}_{3}\right)$ & $6 /(6)$ & - & $1 \mathrm{R}: 0 \mathrm{~S}$ & - \\
\hline L30htht $\left(P_{4}\right)$ & - & $6 /(6)$ & $0 \mathrm{R}: 1 \mathrm{~S}$ & - \\
\hline$F_{1}\left(P_{2} \times P_{1}\right)$ & $8 /(8)$ & - & $1 \mathrm{R}: 0 \mathrm{~S}$ & - \\
\hline$F_{1}\left(P_{2} \times P_{4}\right)$ & - & $8 /(8)$ & OR: $1 \mathrm{~S}$ & - \\
\hline
\end{tabular}

\subsection{Análise de individuos segregantes $R C_{1} F_{1}$ agrupados (ASA)}

Os parentais envolvidos no retrocruzamento (L30HtHtRtRt e L40hthtrtrt), o híbrido $\left(F_{1}\right)$ correspondente [(L30HtHtRtRt $\times$ L40hthtrtrt)] e os "bulks" extremos constituidos, individualmente, pelos segregantes suscetiveis $\left(S_{5}\right)$ e resistentes $\left(R_{1}\right)$, foram genotipados para cada um dos cinco marcadores positivos (BNGL198, MAG01F03, PHI113, MACE01A03, MACTO1E02) identificados via análise de LQIs (símbolo "*", Tabela 4, páginas 57 a 59). O padrão de bandeamento apresentado pelos locos marcadores BNGL198 e 
MAG01F03 (Figura 6), ambos localizados no "bin" 2.08, indicaram a provável ligação destes ao gene de resistência $H t$.

É de se esperar que a detecção de contrastes alélicos entre as amostras $R C_{1} F_{1}\left(R_{1}\right.$ e $\left.S_{5}\right)$ ocorra para aqueles locos marcadores situados dentro da região genômica selecionada e, portanto, somente para aqueles marcadores efetivamente ligados ao gene de interesse. $A$ amostra $S_{5}$ revelou a presença de genótipos marcadores homozigotos para alelos derivados do parental recorrente (L40hthtrtrt), quando genotipada com os locos marcadores BNGL198 e MAG01F03. Esse resultado é conseqüência do agrupamento de indivíduos suscetiveis que são homozigotos não apenas para o loco $H t$ (htht), mas também para a região próxima a esse loco. Por outro lado, o "bulk" resistente $\left(R_{1}\right)$ incluiu o agrupamento de indivíduos heterozigotos para a região que contém esse mesmo loco $(H t)$ e, por isso, foi constatada a presença de alelos derivados de ambos parentais (L30HtHtRtRt e L40hthtrtrt) quando amplificado com os mesmos marcadores (Figura 6). Apesar da definição quanto a constituição genética de cada grupo não ter sido o objetivo desse trabalho, tais resultados indicam que a mistura de DNA do grupo $R_{1}$ inclui indivíduos portadores de genótipos $H$ tht. Os dados disponiveis não permitem inferir a respeito da presença de indivíduos $h$ tht associados a rtrt no "bulk" $\mathrm{R}_{1}$.

Ainda que a amostra suscetível $S_{5}$ também seja constituida por alguns poucos indivíduos recombinantes portadores de alelos marcadores derivados de ambos parentais, há um predomínio de genótipos marcadores constituídos por alelos provenientes do parental L40hthtrtrt. Tal fato é confirmado pela impossibilidade de se visualizar com nitidez a presença de alelos marcadores derivados do parental L30HtHtRtRt que tenham sido amplificados por BNGL198 e MAG01F03. A esse respeito, a literatura relata que quando o alelo raro constitui proporções de até 0,4 (Michelmore et al., 1991) na mistura de DNA da amostra agrupada, ainda poderiam ser detectados polimorfismos entre "bulks" extremos, mesmo que fossem apenas por 


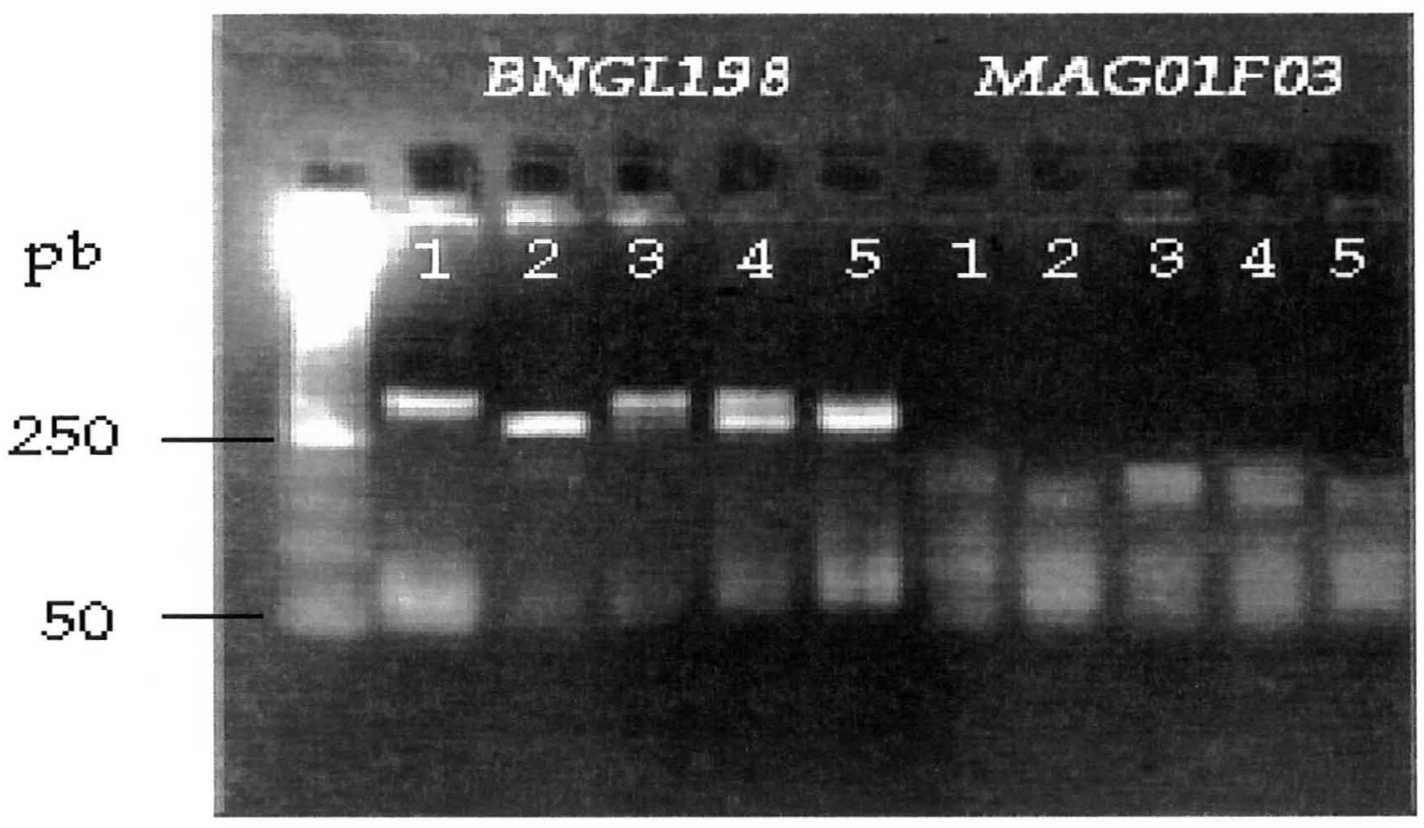

Figura 6 - Polimorfismos de comprimento entre dois "bulks" constituídos por indivíduos suscetíveis ("bulk" $S_{5}$ ) e totalmente resistentes ("bulk" $R_{1}$ ) revelados por dois marcadores microssatélites (BNGL198 e MAG01F03) ligados ao gene $H t$ de resistência a $E$. turcicum. 
diferenças na intensidade de bandas. Os mesmos autores ainda relatam que polimorfismos entre "bulks" obtidos de segregantes $F_{2}$ podem ser sempre detectados quando os locos marcadores estiverem segregando dentro de um intervalo correspondente a $10 \%$ de recombinação de cada lado do gene alvo. Adicionalmente, polimorfismos resultantes de bandas com intensidades desiguais, podem ser detectados para intervalos de recombinação um pouco maiores (Michelmore et al., 1991).

A presença de alelos raros é uma conseqüência da presença de recombinantes dentro de cada amostra selecionada (Michelmore et al., 1991 e Wang \& Paterson, 1994) e é mais grave naqueles casos onde se utliliza uma quantidade relativamente elevada de indivíduos na composição dos "bulks". Essa situação seria especialmente importante para aqueles caracteres muito influenciados pelo ambiente e/ou governados por muitos genes de pequeno efeito fenotípico, uma vez que esses fatores atuando isoladamente ou em conjunto, aumentam as chances de falhas na identificação de polimorfismos entre as amostras extremas (falsos negativos). Adicionalmente, falsos negativos também podem resultar do uso de marcadores dominantes (RAPD, por exemplo) em fase de repulsão com a região de interesse, uma vez que não é possível detectar polimorfismos entre "bulks", mesmo para locos marcadores ligados. No presente trabalho, a fenotipagem dos individuos que compōem os "bulks" foi efetuada para um caráter qualitativo (tipo de lesão) e, paralelamente, as amostras agrupadas $R_{1}$ e $S_{5}$ foram genotipadas com marcadores microssatélites codominantes. Além disso, a taxa de contaminação entre "bulks" em uma população $\mathrm{RC}_{1} \mathrm{~F}_{1}$ é muito menor do que aquela obtida em outras populações (Wang \& Paterson, 1994), uma vez que um indivíduo contaminante no "bulk" $S_{5}$ proveniente de $R_{1}(H t h t)$ teria apenas a metade dos alelos contaminantes provenientes de um "bulk" resistente homozigoto $(\mathrm{HtHt})$ de $F_{2}$.

Locos marcadores identificados como polimórficos entre as 
linhagens quase isogênicas podem não co-segregar com o gene de interesse em nenhuma outra população destinada ao mapeamento. O problema da identificação de falsos positivos inerentes a técnica via LQIs é bastante conhecido e foi eliminado com a estratégia de ASA. Os locos PHI113, MACE01A03 e MACT02E01, por exemplo, não manifestaram contrastes entre os "bulks" $S_{5}$ e $R_{1}$ que fossem indicativos da ligação dos mesmos ao gene $H t$. Essa baixa ocorrência de "bulks" polimórficos para regiões não ligadas ao loco alvo (falsos positivos), deve-se ao fato de ASA identificar polimorfismos para marcadores muito próximos do gene alvo, localizados a menos de $30 \mathrm{cM}$ de distância genética (Michelmore et al., 1991). O número de indivíduos utilizado na composição das amostras (Tingey \& Tufo, 1993) é um fator que afeta a ocorrência desse tipo de erro. Segundo Michelmore et. al., (1988), a quantidade de dez indivíduos já seria suficiente para formar uma pequena "janela" genética disposta simétricamente ao redor do loco de interesse, em contraste a região assimétrica resultante dos retrocruzamentos conduzidos durante a geração das LQIs. Concomitantemente, populações $\mathrm{RC}_{1} \mathrm{~F}_{1}$ estão menos sujeitas a ocorrência de falsos positivos do que $F_{2}$, uma vez que as primeiras apresentam uma "janela" genética em torno da região selecionada ainda menor que as últimas. Nesses casos, os contrastes detectados entre "bulks" resultam do desequilibrio de ligação existente entre dois pontos muito próximos dentro da região alvo. Contrariamente, locos marcadores não ligados ou muito distantes dessa região resultam na ausência de contrastes entre "bulks", desde que os mesmos são suficientemente aleatorizados dentro de cada amostra.

Assim como na análise de LQIs, ASA também é uma estratégia que envolve baixo custo, desde que requer apenas a análise das amostras referentes aos dois "bulks" e seus parentais. A facilidade na construção das amostras agrupadas a partir de qualquer população segregante em desequilíbrio de ligação, faz dessa estratégia a opção mais rápida e eficiente 
de se gerar informações a respeito de marcadores putativamente ligados a uma dada região de interesse. Contudo, ainda é necessária uma análise planta a planta da população segregante $\mathrm{RC}_{1} \mathrm{~F}_{1}$ para confirmar a ligação e estimar a distância entre locos marcadores (BNGL198 e MAG01F03) e gene alvo $(H t)$ e, nesse contexto, ASA serviu para reduzir ainda mais a quantidade de marcadores utilizada nessa etapa de mapeamento do gene $H t$ (seção 4.5).

\subsection{Mapeamento de gene de resistência a E. turcicum pela análise dos indivíduos segregantes da classe recessiva}

Para confirmar a ligação dos marcadores BNGL198 e MAG01F03 ao gene $H t$ utilizou-se uma estratégia de mapeamento idealizada por Zhang et al. (1994), onde apenas os individuos extremos da classe recessiva de uma população segregante $F_{2}$ são usados para a localização de genes de interesse. No presente trabalho, análises de co-segregação entre os citados marcadores e o gene $H t$ foram efetuados com base na genotipagem de 32 plantas $R C_{1} F_{1}$ da classe suscetível $\left(S_{5}\right)$, a partir da qual também foi estimada a localização do referido gene.

O loco BNGL198 apresentou sete genótipos heterozigotos (htht $M_{1} M_{2}$ ) portadores de alelos marcadores $M_{1}$ e $M_{2}$ derivados dos parentais L30HtHtRtRt e L40hthtrtrt, respectivamente, e 25 homozigotos (htht $\mathrm{M}_{2} \mathrm{M}_{2}$ ), portadores de alelos marcadores $M_{2}$ derivados deste último (Figura 7). A genotipagem com o marcador MAG01F03 identificou seis individuos $h$ thtM $M_{3} M_{4}$, portadores de alelos marcadores $M_{3}$ e $M_{4}$ provenientes de ambos parentais (L30HtHtRtRt e L40hthtrtrt), nessa ordem, e 26 homozigotos, portadores de alelos marcadores $M_{4}$ derivados de L40hthtrtrt (Figura 8). Similarmente, a análise conjunta dos genótipos marcadores gerados por ambos marcadores discriminaram um indivíduo com genótipo $M_{1} M_{2} M_{4} M_{4}$, seis com genótipo $M_{1} M_{2} M_{3} M_{4}$ e, finalmente, $25 \quad M_{2} M_{2} M_{4} M_{4}$. Nesse caso, não foi constatado 


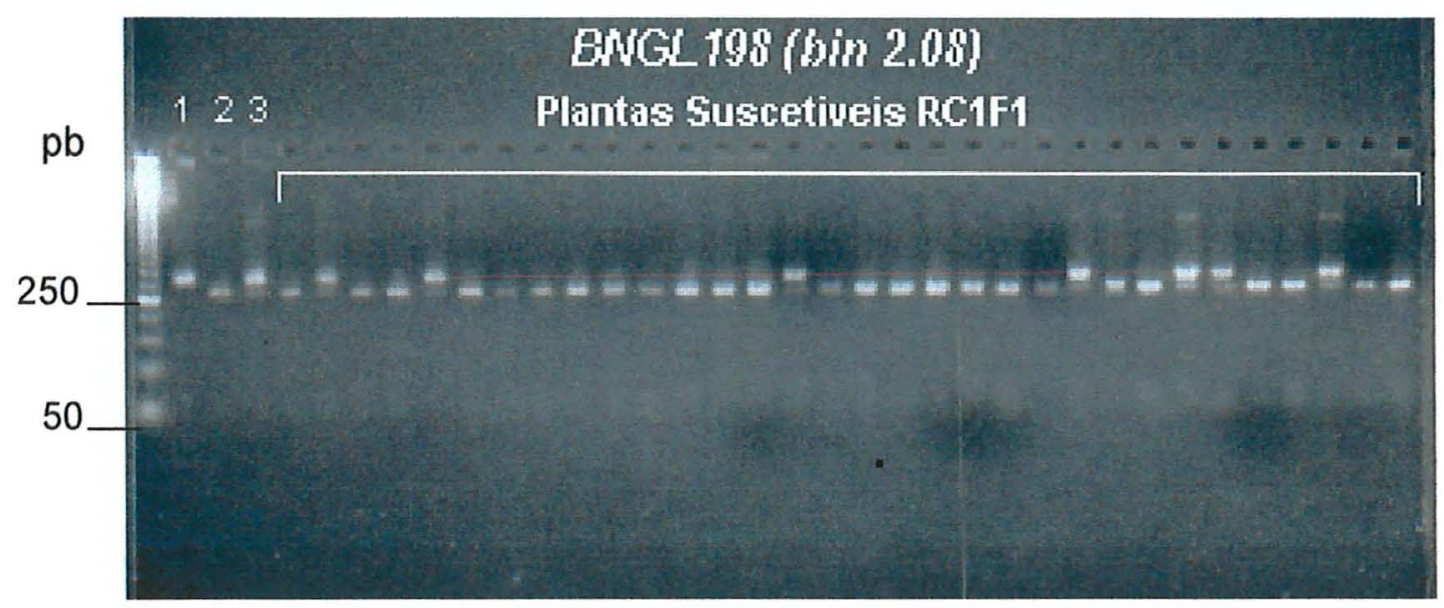

Figura 7 - Genotipagem de indivíduos $\mathrm{RC}_{1} \mathrm{~F}_{1}$ suscetíveis $\left(\mathrm{S}_{5}\right)$ com BNGL198 ("bin" 2.08) que amplifica genótipos heterozigotos recombinantes $\left(M_{1} M_{2}\right)$ para alelos marcadores $M_{1}$ de L30HtHtRtRt (1) e $M_{2}$ de L40hthtrtrt (2) e genótipos homozigotos parentais $\left(\mathrm{M}_{2} \mathrm{M}_{2}\right)$ para alelo marcador $M_{2}$. Indivíduos $F_{1}$ (L30HtHtRtRt $\times$ L40hthtrtrt) com genótipo marcador heterozigoto $M_{1} M_{2}$ (3). 

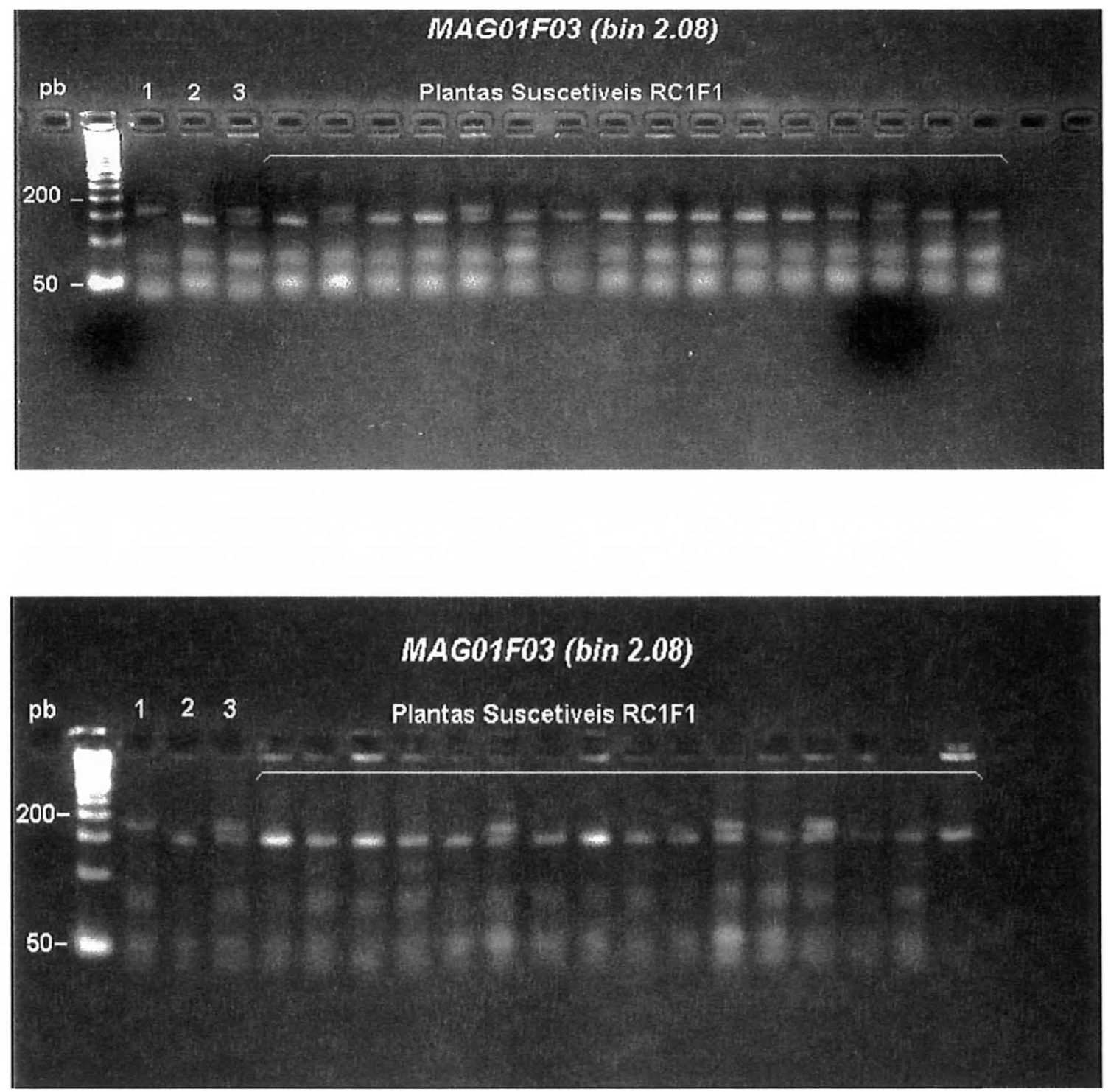

Figura 8 - Genotipagem de indivíduos $R_{1} \mathrm{~F}_{1}$ suscetíveis $\left(\mathrm{S}_{5}\right)$ com MAG01F03 ("bin" 2.08) que amplifica genótipos heterozigotos recombinantes $\left(M_{3} M_{4}\right)$ para alelos marcadores $M_{3}$ de L30HtHtRtRt (1) e $M_{4}$ de L40hthtrtrt (2) e genótipos homozigotos parentais $\left(M_{4} M_{4}\right)$ para alelo marcador $\mathrm{M}_{4}$. Indivíduos $\mathrm{F}_{1}$ (L30HtHtRtRt x L40hthtrtrt) com genótipo marcador heterozigoto $M_{3} M_{4}(3)$. 
nenhum indivíduo com genótipo marcador $M_{2} M_{2} M_{3} M_{4}$ (Figuras 7 e 8 ).

$O$ teste $X^{2}$ mostrou um desvio significativo entre as proporções esperadas de $1 / 2$ hthtM $M_{1}: 1 / 2$ htht $M_{2} M_{2}$ e $1 / 2$ htht $M_{3} M_{4}: 1 / 2$ htht $M_{4} M_{4}$, no caso de segregação independente, e as observadas de $7 / 32$ htht $M_{1} M_{2}: 25 / 32$ htht $M_{2} M_{2}$ e 6/32 htht $M_{3} M_{4}: 26 / 32$ htht $M_{4} M_{4}$, resultantes dos testes de cosegregação efetuados entre o loco $H t$ e os marcadores BNGL198 e MAG01F03, respectivamente (Tabela 8). Em conformidade com o mapa consenso para marcadores microssatélites encontrado em http://www.agron. missouri.edu., o teste $X^{2}$ para a análise de co-segregação entre BNGL198 e MAG01F03 também confirmou a ligação entre esses dois locos marcadores. Tal fato é conseqüência dos desvios entre a proporção esperada $\left(1 / 4 M_{1} M_{2} M_{3} M_{4}\right.$ : $\left.1 / 4 M_{1} M_{2} M_{4} M_{4}: 1 / 4 M_{2} M_{2}, M_{3} M_{4}: 1 / 4 M_{2} M_{2} M_{4} M_{4}\right)$ e os dados observados (6/32 $M_{1} M_{2} M_{3} M_{4}: 1 / 32 \quad M_{1} M_{2} M_{4} M_{4}: 0 / 32 \quad M_{2} M_{2}, M_{3} M_{4}: 25 \quad M_{2} M_{2} M_{4} M_{4}$ ) terem sido altamente significativos (Tabela 8 ).

Dessa forma, foi aceita a hipótese genética alternativa que considera a ligação do alelo $H t$ em fase de associação com os alelos $M_{1}$ e $M_{3}$ derivados de L30HtHtRtRt e amplificados por BNGL198 e MAG01F03, respectivamente, ambos do "bin" 2.08. Por essa razão, os genótipos anteriormente codificados $h t h t M_{1} M_{2}$, htht $M_{2} M_{2}$, htht $M_{3} M_{4}$ htht $M_{4} M_{4}, M_{1} M_{2} M_{4} M_{4}$, $M_{2} M_{2} M_{3} M_{4}, M_{1} M_{2} M_{3} M_{4}$ e $M_{2} M_{2} M_{4} M_{4}$ passam a ser melhor representados por $h t M_{1} / h t M_{2}, h t M_{2} / h t M_{2}, h t M_{3} / h t M_{4}$, htM $/ h t M_{4}, M_{1} M_{4} / M_{2} M_{4}, M_{2} M_{3} / M_{2} M_{4}, M_{1} M_{3} / M_{2} M_{4}$ e $M_{2} M_{4} / M_{2} M_{4}$, respectivamente.

O cálculo da freqüência de recombinação $\left(c_{1}\right)$ assumiu que as 32 plantas suscetíveis eram portadoras de genótipos recessivos para os alelos de suscetibilidade do loco $H t$ ( $h t h t)$. Os valores de $c_{1}$ dos marcadores BNGL198 e MAG01F03 em relação ao loco $H t$ corresponderam a 0,21875 [(7 recombinantes $\left.h t M_{1} / h t M_{2}\right) /\left(7\right.$ recombinantes $h t M_{1} / h t M_{2}+25$ parentais $\left.\left.h t M_{2} / h t M_{2}\right)\right] S_{5} \pm 0,073079$ e 0,18750 [(6 recombinantes $\left.h t M_{3} / h t M_{4}\right) /(6$ recombinantes $h t M_{3} / h t M_{4}+26$ parentais $\left.\left.h t M_{4} / h t M_{4}\right)\right] S_{5} \pm 0,068998$, respectiva- 
Tabela 8 - Teste de ligação genética entre o gene de resistência $H t$ e os marcadores BNGL198 e MAG01F03 ("bin" 2.08) na população segregante (L3OHtHtRtRt $\times$ L4Ohthtrtrt) $\times$ L4Ohthtrtrf.

Locos ligados $\quad \mathrm{FE}^{/ \mathrm{A}} \quad \mathrm{FO}^{/ 8} \quad \mathrm{X}^{2 / \mathrm{C}} \quad \mathrm{c}_{1}{ }^{10} \quad \mathrm{~V}_{\mathrm{c}}^{1 / 2 / \mathrm{E}}$

Ht / bngl $198^{/ F}$

**

21,87

5,17

$h t h t M_{1} M_{2}$

16

7

hthtM $M_{2}$

16

25

Ht / MAG01F03 ${ }^{\text {IG }}$

htht $M_{3} M_{4}$

16

6

18,75

4,88

$h$ tht $M_{4} M_{4}$

16

26

$M_{1} / M_{2}{ }^{1 \mathrm{H}}$

**

3,125

2,18

$M_{1} M_{2} M_{3} M_{4}$

8

6

$M_{1} M_{2} M_{4} M_{4}$

8

1

$M_{2} M_{2}, M_{3} M_{4}$

8

0

$M_{2} M_{2} M_{4} M_{4}$

8

25

FO : freqüência observada ${ }^{/ A} ; \mathrm{FE}$ : freqüência esperada no caso de segregação independente ${ }^{1 B}$; nivel de significância do teste $X^{2 / C}$, com $\left(^{*}\right)=0,05>P>0,01$, $\left({ }^{* *}\right)=P<0,01$ e (ns) = não significativo; $c_{1}$ : freqüência de recombinação em percentagem ${ }^{1 D} ; V_{c}^{1 / 2}$ : erro padrão da estimativa de recombinação em percentagem $^{I E}$. Hipóteses genéticas tetadas: $1 / 2\left(h\right.$ tht $\left.M_{1} M_{2}\right): 1 / 2\left(h t^{2} t M_{2} M_{2}\right)^{1 F}, 1 / 2$ $\left(h\right.$ tht $\left.M_{3} M_{4}\right): 1 / 2\left(h t h t M_{4} M_{4}\right)$ e $1 / 4\left(M_{1} M_{2} M_{3} M_{4}\right): 1 / 4\left(M_{1} M_{2} M_{4} M_{4}\right): 1 / 4\left(M_{2} M_{2}, M_{3} M_{4}\right)$ : $1 / 4\left(M_{2} M_{2} M_{4} M_{4}\right)^{1 / H}$. 
mente $e$, a freqüência de recombinação entre os dois marcadores (BNGL198 e MAG01F03) foi de 0,03125 [(1 recombinante $M_{1} M_{4} / M_{2} M_{4}+0$ recombinante $\left.M_{2} M_{3} / M_{2} M_{4}\right) /\left(1\right.$ recombinante $M_{1} M_{4} / M_{2} M_{4}$ e 0 recombinante $M_{2} M_{3} / M_{2} M_{4}+31$ parentais $M_{1} M_{3} / M_{2} M_{4}$ e $\left.\left.M_{2} M_{4} / M_{2} M_{4}\right)\right] \pm 0,030758$. Isso significa que o loco $\mathrm{Ht}$ sob análise está localizado no braço longo do cromossomo 2 a cerca de 21,8750 e de 18,7500 unidades de recombinação dos locos BNGL198 e MAG01F03, nessa ordem, e que os dois marcadores estão a uma distância de 3,1250 unidades de recombinação um do outro. Em termos de unidades de distância de mapa, esses valores foram de $28,7682 \mathrm{cM}, 23,5000 \mathrm{cM}$ e 3,2269 $\mathrm{cM}$, respectivamente, segundo estimativas efetuadas através da função de mapeamento de Haldane (1919), a qual faz ajustes às distâncias calculadas $\left(c_{1}\right)$ com base na ocorrência de duplos crossovers (Figura 9).

O gene de resistência $H t_{1}$ foi identificado há cerca de 35 anos atrás (Hooker, 1963); está localizado no braço longo de cromossomo 2, na posição 121 (2L-121) do mapa de ligação consensual, entre W3 (2L-111, define coloração do endosperma e "seedling", segundo Coe et al., 1990 ) e Ch1 (2L155 , define coloração do pericarpo, segundo Coe et al., 1990). Alguns estudos conduzidos com marcadores moleculares também têm demonstrado a existência de correlações entre esse gene e vários locos RFLPs situados sobre o cromossomo 2L. Gardiner et al. (1993), por exemplo, correlacionaram a presença de $H t_{1}$ em cinco dentre seis linhagens de milho convertidas para esse gene, localizando-o em um segmento do cromossomo $2 \mathrm{~L}$, flanqueado pelo marcador RFLP designado UMC122. Ma (1991) encontrou esse mesmo gene de resistência a uma distância de $20,9 \pm 5,1 \mathrm{cM}$ e 23,5 \pm 4,6 cM dos marcadores RFLPS BNL6.20 e UMC49, respectivamente, mediante a análise de 58 indivíduos $F_{2}$ obtidos a partir do cruzamento de duas LQIs, contrastantes entre si pela presença do referido gene. Similarmente, Bentolila et al. (1991) analisaram 95 segregantes da população $F_{2}$ e identificaram um marcador RFLP (UMC150B) a uma distância de $1 \mathrm{cM}$ em relação ao gene de resistência 
$H t_{1}$. Mais recentemente, Coe et al. (1995) publicaram o mapa genético de vários genes do milho (incluindo $H t_{1}$ ) acompanhando o mapa RFLP e foi definido que $H t_{1}$ está a $168 \mathrm{cM}$ do ponto zero do cromossomo, flanqueado de um lado pelo marcador UMC22 a uma distância de $4,3 \mathrm{cM}$ e do outro lado pelo marcador UMC122 a 1,2 cM. McMullen \& Simcox (1995) fazem referência ao "bin" 2.08 como o suposto loco do gene $H t_{1}$. Esses dados sugerem a possibilidade do gene $H t$ aqui descrito estar ligado a $H t_{1}$ ou, alternativamente, que o primeiro seja uma outra forma alélica do segundo.

A posição do gene de resistência $H t$ aqui analisado em relação aos marcadores BNGL198 e MAG01F03 e destes últimos em relação a UMC49a está representada na Figura $9 \mathrm{com}$ base nas informações obtidas a partir dos testes de co-segregação conduzidos no presente trabalho e no mapa consenso de milho de McMullen et al. (1998). Estas referências mostram que o loco UMC49a está posicionado no bordo terminal do "bin" 2.08 a cerca de 23,5 cM do gene de resistência $H t_{1}(\mathrm{Ma}, 1991)$ e mais próximo a BNGL198 do que MAG01F03. Partindo do pressuposto que os marcadores BNGL198 e MAG01F03 estão localizados acima do bordo inferior do "bin" 2.08 (http://www.agron.missouri.edu) e que a distância estimada desses locos em relação ao gene $H t$ é de $28,77 \mathrm{cM}$ e $23,50 \mathrm{cM}$, respectivamente, então os mesmos possivelmente estão situados entre o loco Ht de L30HtHtRtRt e o marcador UMC49a.

\subsection{Identificação de raças e do espectro de resistência conferido pelo gene $\boldsymbol{H t}$}

A reação de cinco linhagens diferenciadoras $\left(\mathrm{Pa}, \mathrm{PaHt}, \mathrm{Pa} H t_{2}, \mathrm{~Pa}\right.$ $\left.\mathrm{Ht}_{3}, \mathrm{~Pa} H t \mathrm{~N}\right)$, das linhagens L30HtHtRtRt (convertida), L30hthtRtRt (recorrente), L30HthtRtrt e L40hthtrtrt e dos hibridos L30HtHtRtRt x L40hthtrtrt e L30hthtRtRt $x$ L40hthtrtrt, frente a cinco isolados de Exserohilum turcicum, está apresentada 
"Bin" 2.08

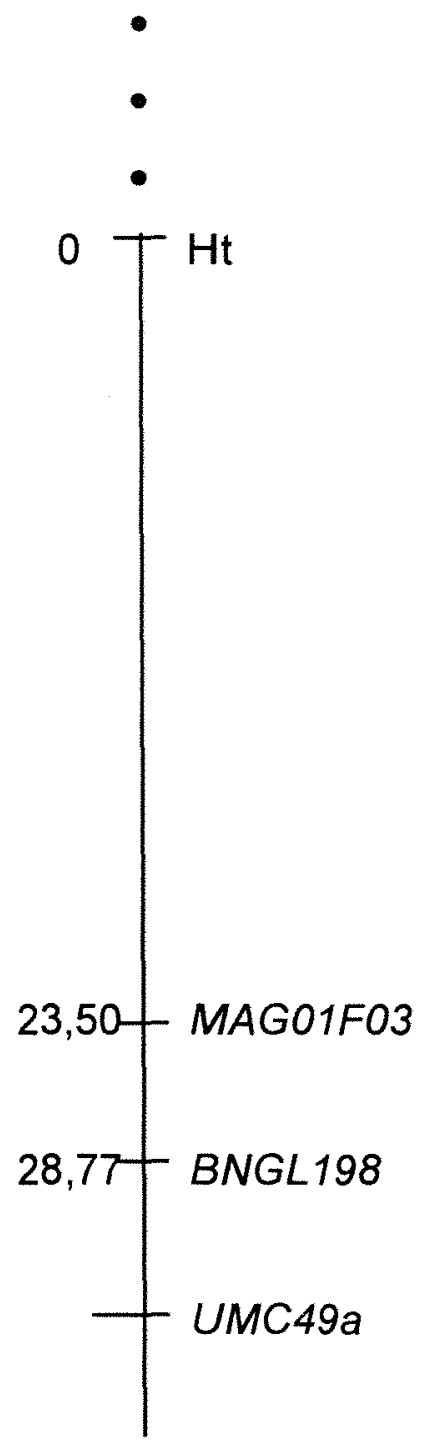

Figura 9 - Mapa de ligação do cromossomo $2 \mathrm{~L}$ mostrando a região próxima ao gene $H t$ derivado de L30HtHtRtRt. As distâncias entre o referido gene e os marcadores BNGL198 e MAG01F03 foram estimadas em centimorgans mediante a função de mapeamento de Haldane (1919) e a posição dos mesmos em relação a UMC49a foi obtida do mapa consenso de milho. 
na Tabela 9. Durante a condução desse ensaio, a temperatura mínima e máxima esteve situada entre 13 e $29^{\circ} \mathrm{C}$, respectivamente, o que corresponde à temperatura média ideal $\left(20^{\circ} \mathrm{C}\right)$ recomendada por Leonard et al. (1989) para ensaios de identificação de raças. Nestas condições, plantas resistentes $\left(R_{1}\right.$, $R_{2}, R_{3}$ e $R_{4}$ ) produziram lesões clorótico-necróticas ou não produziram nenhum tipo de lesão, enquanto plantas suscetiveis $\left(S_{5}\right.$ e $\left.S_{6}\right)$ reagiram produzindo lesões necróticas de cor palha verde-olivácea (Figura 10) e até alaranjada.

O conjunto de genótipos analisados na Tabela 9 permitiu detectar a presença de pelo menos três raças fisiológicas, classificadas conforme sistema proposto por Leonard et al. (1989). O isolado 49, por exemplo, com fórmula de virulência $\mathrm{Ht}, \mathrm{Ht}_{1}, \mathrm{HN} / \mathrm{O}, \mathrm{Ht}_{2}, \mathrm{Ht}_{3}$, $\mathrm{t}$ para genes de resistência efetivos/inefetivos a E. turcicum, produziram lesões necróticas tipo suscetível em $\mathrm{Pa}, \mathrm{PaHt}, \mathrm{PaHt}$, L30hthtRtRt, $F_{1} h$ thtRtrt e L40hthtrtrt e lesões clorótico-necróticas tipo resistentes em PaHt $t_{1} \mathrm{PaHtN}, \mathrm{L} 30 \mathrm{HtH}$ tRtRt, L30HthtRtRt e $\mathrm{F}_{1} H$ thtRtrt e, por essa razão, passou a ser reconhecido como raça 23 r. Isso indica que essa raça ainda não relatada na literatura, além de superar a resistência conferida pelos genes $\mathrm{Ht}_{2}$ e $\mathrm{Ht}_{3}$, presentes individualmente nas cultivares diferenciais, também foi capaz de vencer o alelo de resistência recessivo $(r t)$ do loco $R t$, presente em L40hthtrtrt. Devido a reação de resistência de L30HtHtRtRt/L30HthtRtRt e suscetibilidade de L30hthtRtRt, conclui-se que a raça em questão não é portadora de fatores de virulência capazes de superar $H t$.

Os isolados 18 e 48 produziram lesões necróticas do tipo suscetível alaranjada e palha-verde olivácea, respectivamente, quando inoculados sobre $\mathrm{Pa}, \mathrm{PaHt} t_{1}, \mathrm{PaHt}_{2}, \mathrm{PaHt} t_{3} \mathrm{PaHtN}$ e ausência de lesões e lesões cloróticonecróticas tipo resistentes, nessa ordem, sobre $F_{1} H$ thtRtr e $F_{1}$ hthtRtrt e, portanto, ambos podem ser representados pela fórmula de virulência $\mathrm{x} / 0, H t_{1}, H t_{2}, H t_{3}, H t N$ (genes efetivos/inefetivos, respectivamente). Apesar dos isolados 18 (raça 12N, segundo Gianasi, 1996) e 48 terem sido aqui identificados como raça $123 \mathrm{~N}$, acredita-se que tratam-se de dois biótipos diferentes, em vista de terem apresentado reações de resistência e suscetibili- 
Tabela 9 - Reação das linhagens diferenciadoras $\mathrm{Pa}, \mathrm{PaHt}, \mathrm{Pa} H t_{2}, \mathrm{~Pa} H t_{3}, \mathrm{~Pa}$ HtN, das linhagens L30HtHtRtRt (convertida), L30hthtRtRt (recorrente), L30HthtRtht e L40hthtrtrt e dos hibridos L30HtHtRtRt x L40hthtrtrt e L30hthtRtRt $\times$ L40hthtrtrt, inoculados com cinco isolados de Exserohilum turcicum, provenientes de São Paulo (isolados 18, 47 e 53), Mato Grosso do Sul (isolado 48) e Paraná (isolado 49).

Isolados

\begin{tabular}{|c|c|c|c|c|c|}
\hline \multirow[b]{2}{*}{ Genótipos } & \multicolumn{5}{|c|}{ Isolados } \\
\hline & 18 & 47 & 48 & 49 & 53 \\
\hline $\mathrm{Pa}$ & $S$ & $S$ & $S$ & $S$ & $S$ \\
\hline $\mathrm{PaHt} t_{1}$ & $S$ & $S$ & $S$ & $\mathrm{R}$ & $S$ \\
\hline $\mathrm{PaHt}_{2}$ & $S$ & $S$ & S & $S$ & $S$ \\
\hline $\mathrm{PaHt}_{3}$ & $S$ & $S$ & $S$ & $S$ & $S$ \\
\hline $\mathrm{PaHtN}$ & $S$ & $\mathrm{R}$ & S & $\mathrm{R}$ & $\mathrm{R}$ \\
\hline L30HtHtRtRt & $\mathrm{R}$ & $\mathrm{R}$ & $n$ & $\mathrm{R}$ & $n$ \\
\hline L30hthtRtRt & $\mathrm{R}$ & $S$ & $n$ & $S$ & $n$ \\
\hline L30HthtRtrt & $\mathrm{R}$ & $\mathrm{R}$ & $n$ & $\mathrm{R}$ & $n$ \\
\hline L40hthtrtrt & $\mathrm{R}$ & $\mathrm{R}$ & $n$ & $S$ & $n$ \\
\hline $\mathrm{F}_{1} H$ thtRtrt ${ }^{1 \mathrm{~A}}$ & $\mathrm{R}$ & $\mathrm{R}$ & $\mathrm{R}$ & $\mathrm{R}$ & $\mathrm{R}$ \\
\hline $\mathrm{F}_{1}$ thtRtrt $^{1 \mathrm{~B}}$ & $\mathrm{R}$ & $S$ & $\mathrm{R}$ & s & $S$ \\
\hline Virulência & $123 N$ & 123 & $123 N$ & $23 r$ & 123 \\
\hline
\end{tabular}

\footnotetext{
${ }^{1 A}$ Hibridos simples (L30HtHtRtRt $\times$ L40hthtrtrt) $e^{1 B}$ (L30hthtRtRt $\times$ L40hthtrtrt); n, significa "sem informações". $R$ atribuída a plantas com reações $R_{1}, R_{2}, R_{3}, R_{4}$ e $S$ para plantas com reações $S_{5}$ e $S_{6}$, segundo Esteves (1989).
} 

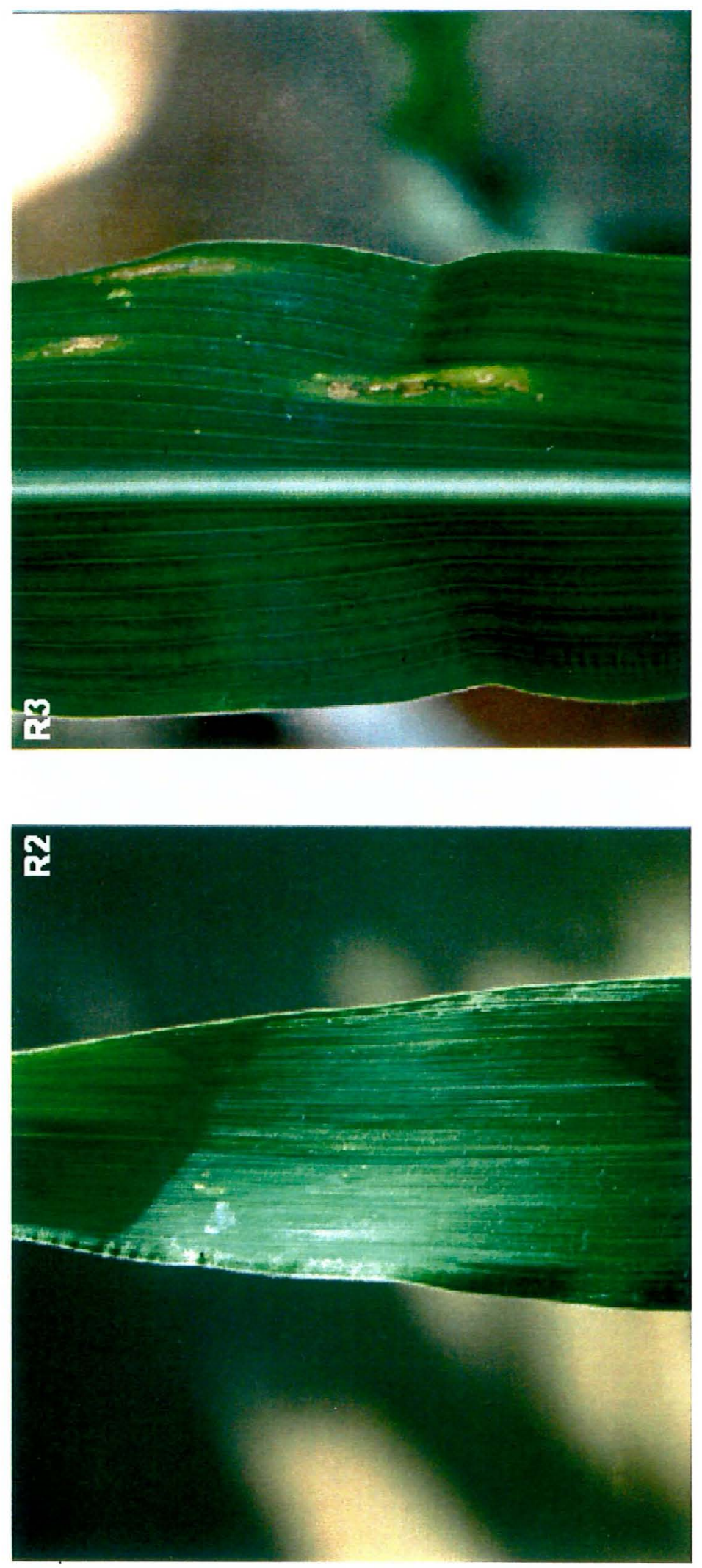

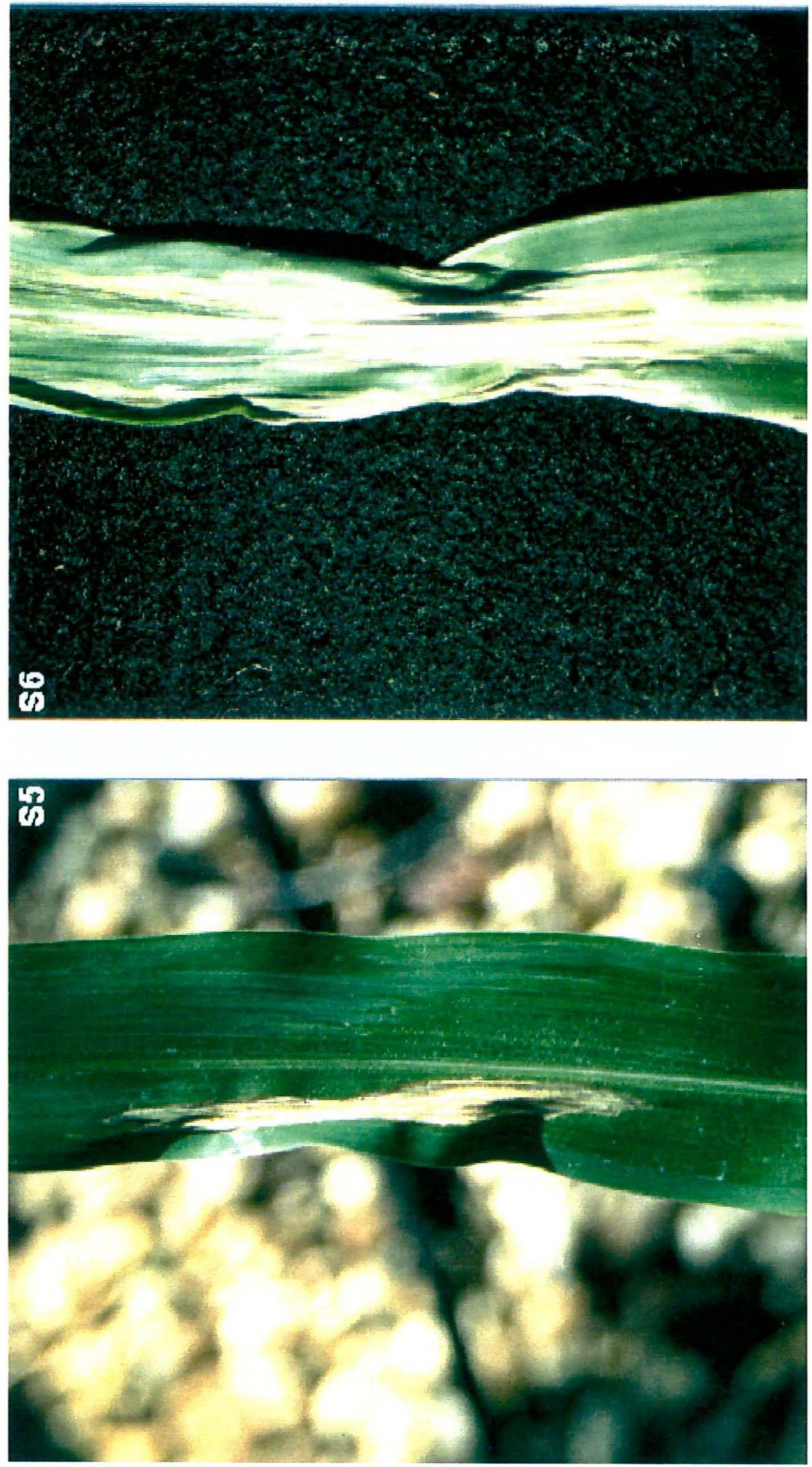

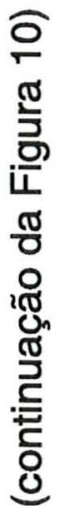


dade distintas sobre o conjunto de diferenciadoras, linhagens e híbridos analisados. A reação de resistência apresentada por L30HtHtRtRt, L30HthtRtRt, L30hthtRtRt, $F_{1} H$ thtRtrt e $F_{1}$ hthtRtrt frente ao isolado 18 , indica a presença de algum outro gene diferente de $H t$ presente em L30HtHtRtRt L30HthtRtRt/L30hthtRtRt como um dos responsáveis pela resistência conferida ao isolado 18. Faltam elementos para inferir se a resistência de L30HtHtRtRt frente a ambos isolados também seria conferida por $\mathrm{Ht}$ e a de L40hthtrtrt por rt.

Finalmente, os isolados 47 e 53 produziram lesões tipicamente suscetíveis em $\mathrm{Pa}, \mathrm{PaHt}_{1}, \mathrm{PaHt}_{2}, \mathrm{PaHt}_{3}$ e $\mathrm{F}_{1}$ hthtRtrt e lesões tipicamente resistentes em $\mathrm{PaHtN}$ e $\mathrm{F}_{1} H$ thtRtrt e, por essa razão, podem ser representados pela fórmula de virulência $H t, H t N / O, H t_{1}, H t_{2}, H t_{3}$ e serem, portanto, classificados como raça 123. É possível que os mesmos ainda pertençam ao mesmo biótipo, pois além de possuírem mesmo espectro de virulência também são procedentes do mesmo municipio (Cravinhos-SP). Particularmente para 0 isolado 47 ainda foram obsevadas lesões do tipo suscetível em L30hthtRtRt e do tipo resistente em L30HtHtRtRt, L30HthtRtRt e L40hthtrtrt.

Mediante o conjunto de genótipos analisados ( $\mathrm{Pa}, \mathrm{PaHt}_{1}, \mathrm{PaHt}_{2}$, $\mathrm{PaHt}_{3}, \mathrm{PaHtN}, \mathrm{L} 30 \mathrm{HtHtRtRt}$, L30hthtRtRt, L40hthtrtrt, $\mathrm{F}_{1} H$ thtRtrt e $\mathrm{F}_{1}$ hthtRtrt) não foi possivel definir se a resistência de L40hthtrtrt ao isolado 53 foi conferida pelo alelo recessivo it ou um outro gene presente em L40hthtrtrt. Contudo, a ineficácia do alelo ht frente ao isolado 47 (L30HtHtRtRt e L30HthtRtRt: R e L30hthtRtRt: S) e a evidência fornecida pelos locos Ht e Rt como únicos responsáveis pela segregação observada na população $R_{1} F_{1}[(L 30 H t H t R t R t x$ L40hthtrtrt) $\times$ L40hthtrtrf] (item 4.3), permitiu atribuir a resistência de L40hthtrtrt diante de 47 ao suposto alelo recessivo $r$. Portanto, a virulência do isolado 47 seria melhor representada pela fórmula $H t, H t N, r t / 0, H t_{1}, H t_{2}, H t_{3}$.

Os dados sugerem que os isolados 47 e 53, agora classificados como raça 123 , conseguiram superar a resistência conferida pelos alelos $H t_{1}$, $\mathrm{Ht}_{2}$ e $H t_{3}$, mas não a resistência dos alelos $H t N$ e $H t$, este último introgredido em 
L30HtHtRtRt. Adicionalmente, o isolado 47 também não conseguiu vencer a resistência de $r t$ presente em L40hthtrtrt. Portanto, apesar de $H t$ e $H t_{1}$ estarem localizados na mesma região do genoma ("bin" 2.08), não se pode admitir que os mesmos sejam idênticos, já que seus espectros de resistência são distintos. Com base nessas informações, o gene dominante $H t$, até então de identidade desconhecida, passará a ser designado $H t P$, em vista do municipio de Piracicaba ter sido o local da descoberta deste gene. Similarmente, os espectros de virulência dos isolados 47,49 e 53 serão representados pelas fórmulas $H t P, H t N, r t / O, H t_{1}, H t_{2}, H t_{3}, H t P, H t_{1}, H N I O, H t_{2}, H t_{3}, r t$ e $H t P, H t N / O, H t_{1}, H t_{2}$, $\mathrm{Ht}_{3}$, nessa ordem.

Esse é o primeiro registro de mapeamento genético e de determinação do espectro de resistência do gene HtP em milho, possivelmente, um alelo alternativo ou um novo gene muito próximo do loco $H t_{1}$, também localizado no cromossomo 2 (Bentolila et al., 1991; Ma, 1991; McMullen \& Simcox, 1995). Hooker (1980) já havia sugerido a existência de duas formas alélicas de resistência para esse loco. Portanto, $H t P$, se localizado no mesmo loco, seria uma forma alélica alternativa que confere resistência a isolados com amplo espectro de virulência, tal como aquele observado para as raças 123 e $23 r$, aqui identificadas.

Segundo Gianasi et al. (1996), programas que visam a resistência qualitativa a $E$. turcicum poderiam incorporar qualquer um dos genes de resistência $H t s\left(H t_{1}, H t_{2}, H t_{3}\right.$ e $\left.H t N\right)$, uma vez que os mesmos condicionam resistência a raça 0 , que é a raça predominante na maioria dos locais de cultivo de milho do País. Por outro lado, o gene HtP foi capaz de conferir resistência

aos fatores de virulência aqui analisados 1, 2, 3 er. Estes resultados sugerem a utilização da resistência qualitativa oferecida pelo gene $H t P$ nos programas de melhoramento à doenças, pelo menos, até o momento que surja uma nova raça capaz de superá-lo. A partir desse ponto, a comprovação da existência de efeito residual em $H t P$, a exemplo do que ocorre com $H t_{1}$ (Leath \& Pedersen, 1984 e 1986), ainda poderia garantir sua utilização dentro de um 
esquema de piramidamento de genes superados pelo patógeno, conforme proposta de Nelson (1978).

Diversamente ao observado para outros caracteres qualitativos, é evidente o significativo efeito do ambiente sobre a expressão dos genes de virulência e de resistência para o sistema patógeno-hospedeiro em questão (Leath et al., 1987; Leath et al., 1990; Leonard et al., 1989; Thakur et al., 1989a; Thakur et al. 1989b). Certamente, esse é um fator que dificulta a seleção de genótipos resistentes e, por essa razão, é justificável usufruir das vantagens de um esquema de seleção orientada pelos marcadores moleculares, ainda que se esteja trabalhando com genes de resistência qualitativa, tal como o gene HtP.

Alguns estudos adicionais devem ser conduzidos para elucidar questões decorrentes desse trabalho, tal como a definição das condições ambientes que favorecem a expressão dos genes $H t P$ e $r$; efeito residual de $H t P$ e $r t$ frente a possiveis isolados virulentos; interação dos mesmos com genes que conferem resistênca parcial a $E$. turcicum e seus conseqüentes resultados epidemiológicos; identificação de raças com um conjunto de diferenciadoras que contemple a incorporação individual de $H t P$ e $t$; 0 mapeamento do suposto alelo de resistência recessiva $(r t)$ presente em L40hthtrtrt; testes de alelismo entre $H t P$ e $H t_{i}$; a saturação da região portadora de HtP com outros marcadores moleculares e; seqüenciamento desses genes e subseqüente comparação à outras regiões responsáveis pela resistência a $E$. turcicum e a outras doenças em plantas. 


\section{CONCLUSÕES}

O presente estudo permitiu as seguintes conclusões:

a) a maioria dos pares de "primers" de microssatélites de milho (79) analisados amplificam produtos de boa qualidade no programa básico da PCR (programa 1, definido na seção 3.3), independente da temperatura de anelamento estimada como ideal para cada componente do par;

b) os restantes 46 pares de "primers", exigiram condições otimizadas de temperatura de anelamento e/ou concentração de "primers";

c) a correspondência entre os valores esperados e observados quanto a quantidade de marcadores do parental doador retida no genoma (até 5) da linhagem convertida e também próximo a região que contém o gene introgredido (até 3), confirmou a validade da análise de linhagens quase isogênicas mediante marcadores microssatélites;

d) a estratégia de análise de linhagens quase isogênicas associada a análise dos segregantes agrupados e dos indivíduos extremos da classe recessiva permitiu identificar dois marcadores microssatélites - BNGL198 e MAG01F03 - ligados ao gene Ht introgredido em L30HtHtRtRt, ambos localizados no braço longo do cromossomo 2 ("bin" 2.08 ) a cerca de $28,77 \mathrm{cM}$ e 23,50 cM de distância genética de mapa, respectivamente;

e) as informações de mapeamento e a definição do espectro de resistência do gene introgredido em $L 30 H t H t R t R t$ permitiram verificar que o gene introgredido em L3OHtHtRtRt é um novo gene localizado próximo a $\mathrm{Ht}_{1}$ ou uma forma alélica alternativa do mesmo, aqui designado $H t P$;

f) foram identificadas pelo menos três raças portadoras das fórmu- 
las de virulência $x / H t_{1}, H t_{2}, H t_{3}, H t N$ (isolado 18 e 48), $H t P, H t N, r t / H t_{1}, H t_{2}, H t_{3}$ (isolado 47) $\mathrm{HtP}, \mathrm{HtN} / \mathrm{Ht}_{1}, \mathrm{Ht}_{2}, \mathrm{Ht}_{3}$ (isolado 53) e $\mathrm{HtP}, \mathrm{Ht}_{1}, \mathrm{HtN} / \mathrm{Ht}_{2}, \mathrm{Ht} t_{3}, \mathrm{rt}$ (isolado 49) e nenhuma delas foi capaz de superar a resistência conferida por HtP;

g) o isolado 49 , com fórmula de virulência $H t P, H t_{1}, H t N / H t_{2}, H t_{3}, r t$, é uma nova raça de $E$. turcicum ainda não relatada na literatura, capaz de superar a resistência conferida por $\mathrm{Ht}_{2}, \mathrm{Ht}_{3}$ e $\mathrm{r}$;

h) o gene HtP confere resistência às raças portadoras de amplo espectro de virulência, tais como 123 e $23 \mathrm{r}$ e, portanto, a sua introgressão é recomendada em cultivares comerciais híbridas e variedades de milho brasileiras;

i) apesar de cerca $50 \%$ dos locos marcadores analisados terem revelado monomorfismos entre parental doador e recorrente, a quantidade de 125 marcadores microssatélites foi suficiente tanto para avaliar a eficiência de um programa de retrocruzamento de milho para a introgressão de um gene de resistência a E. turcicum, bem como para selecionar locos marcadores ligados a esse gene. 


\section{REFRERÊNCIAS BIBLIOGRÁFICAS}

ADAM-BLONDON, A.F.; SÉVIGNAE, M.; BANNEROT, H.; DRON, M. SCAR, RAPD and RFLP markers linked to a dominant gene (Are) conferring resistance to anthracnose in common bean. Theoretical and Applied Genetics, v.88, p.865-870, 1994.

AKKAYA, M.S.; BHAGWAT, A.A.; CREGAN, P.B. Length polymorphisms of simple sequence repeat DNA in soybean. Genetics, v.132, p. 1131-1139, 1992.

ALLARD, R.W. Formulas and tables to facilitate the calculation of recombination values in heredity. Hilgardia, v.24, p235-277, 1956.

ARNHEIM, N.; STARNGE, C.; ERLICH, H. Use of pooled DNA samples to detect linkage disequilibrium of polymorphic restriction fragments and human disease: studies of the HLA class II loci. Proceedings National Academy of Sciences USA, v.82, p.6970-6974, 1985.

BAI, D.; REELEDER, R.; BRANDLE, J.E. Identification of two RAPD markers tightly linked with the Nicotiana debneyi gene for resistance to black root rot of tobacco. Theoretical and Applied Genetics, v.91, p.1184-1189, 1995. 
BARUA, U.M.; CHALMERS, K.J.; HACKETT, C.A.; THOMAS, W.T.B.; POWEL, W.; WAUGH, R. Identification of RAPD markers linked to a Rhynchosporium secalis resistance locus in barley using near-isogenic and bulked segregant analysis. Heredity, v.71, p.177-184, 1993.

BECKMANN, J.S.; SOLLER, M. Towards a unified approach to the genetic mapping of eukaryotes based on sequence-tagged microsatellite sites. BioTechnology, v.8, p.930-932, 1990.

BELL, C.J.; ECKER, J.R. Assignment of 30 microsatellite loci to the linkage map of Arabidopsis. Genomics, v.19, p.137-144, 1994

BENTOLILA, S.; GUITTON, C.; BOUVET, N.; SAILAND, A.; NYKAZA, S.; FREYSSINET, G. Identification of RFLP marker tightly linked to the Ht1 gene in maize. Theoretical and Applied Genetics, v.82, p.393-398, 1991.

BERQUIST, R.R.; MASIAS, O.R. Physiologic specialization in Thrichomestasphaeria turcica f.sp. zeae and $T$. turcica f.sp. sorghi in Hawaii. Phytopathology, v.64, p.645-649, 1974.

BOROVKOVA, I.G.; STEFFENSON, B.J.; JIN,Y.; RASMUSSEN, J.B.; KILIAN, A.; KLEINHOFS, A.; ROSSNAGEL, B.G.; KAO, K.N. Identification of molecular markers linked to the stem rust resistance gene rpg4 in barley. Phytopathology, v.85, p.181-185, 1995.

BORLAUG, N.E.; GILBER, J.W. The use of flexible composite wheat varieties to control the constantly changing stem rust pathogen. Agronomy Abstracts of the American Society of Agronomy, p.81, 1953. 
BROWN, S.M.; SZEWC-MCFADDEN, A.K.; KRESOVICH, S. Development and application of simple sequence repeat (SSR) loci for plant genome analysis. In: JAUHAR; P.P.(Ed.) Methods of genome analysis in plants. Boca Raton: CRC Press, 1996. cap.9, p.147-159.

BROWERS, J.E.; DANGI, G.S.; VIGNANI, R.; MEREDITH, C.P. Isolation and characterization of new polymorphic simple sequence repeat loci in grape (Vitis vinifera L.). Genome, v.39, p.628-633, 1996.

CABALLOS, H.; GRACEN, V.E. A dominant Inhibitor gene inhibits the expression of $\mathrm{Ht}_{2}$ against Exserohilum turcicum race 2 in corn inbred lines related to B14. Plant Breeding, v.102, p.35-44, 1989.

CARSON, M.L. Inheritance of latent period lenght in maize infected with Exserohilum turcicum. Plant Disease, v.79, p.581-585, 1995.

CARSON, M.L.; VAN DYKE, C.G. Effect of light and temperature on expression of partial resistance of maize to Exserohilum turcicum. Plant Disease, v.78, n.5, p.519-522, 1994.

CARSON, M.L.; WICKS, Z.W. Response of a maize synthetic to $S 1$ recurrent selection for grain yield in a desease-stress environment. Maydica, v.38, p.193-199, 1993.

CHAGUÉ, V.; MERCIER,J.C.; GUÉNARD, M.; COURCEL, A. de; VEDEL, F. Identification of RAPD markers linked to a locus involved in quantitative resistance to TYLCV in tomato by bulked segregant analysis. Theoretical and Applied Genetics, v.95, p. 671-677, 1997. 
CHARLESWORTH, B.; SNIEGOWSKY, P.; STEPHAN, W. The evolutionary dynamics of repetitive DNA in eukaryotes. Nature, v.371, p.215-220, 1994.

CHIN, E.C.L.; SENIOR, M.L.; SHU, H.; SMITH, J.S.C. Maize simple repetitive DNA sequences: abundance and allellic variation. Genome, v.39, p.866873, 1996.

CHYI, Y.; GUPTA, M.; FROME, M.J.; PARK, F.D.; HOOD, B.; ZAITLIN, D.; BANKS, W.D.; PERKINS, J.; FILNER, P. Identification of RFLP markers for the rbm gene. Maize Genetics Cooperation Newsletter, v.63, p.112, 1989. /Resumo/

CLIFFORD, B.C. Stable resistance to cereal disease: problems and progress. Aberystwyth: Welsh Plant Breed Station. 1975, p.107-113.

COE, E; HOISINGTON, D.; CHAO, S. Gene List and Working Maps. Maize Genetics Cooperation Newsletter, v.64, p.134-148, 1990.

COE, E.; HANCOCK, D.; KOWALEWSKI, S.; POLACCO, M. Gene List and Working Maps. Maize Genetics Cooperation Newsletter, v.69, p.247-256, 1995.

CONDIT, R.; HUBBELL, S.P. Abundance and DNA sequence of two-base repeat regions in tropical tree genomes. Genome, v.34, p.66-71, 1991.

DAVIS, G.; MCMULLEN, M.; COE, E.; POLACCO, M. Working maps. Maize Genetics Cooperation Newsletter, v.70, p.123-132, 1996. 
DIERS, B.W.; MANSUR, L.; INSANDE, J.; SHOEMAKER, R.C. Mapping Phytopthora resistance loci in soybean with restriction fragment length polymorphism markers. Crop Science, v.32, p.377-383, 1992.

EDWARDS, A.; CIVITELLO, A.; HAMMOND, H.A.; CASKEY, C.T. DNA typing and genetic mapping with trimeric and tetrameric tandem repeats. American Journal of Human Genetics, v.49, p.746-756, 1991.

ELLSWORTH, D.L.; RITTENHOUSE, K.D.; HONEYCUTT, R.L. Artifactual variation in randomly amplified polymorphic DNA banding patterns. Biotechniques, v.14, n.2, p.214-217, 1993.

ESTEVES, M. C. F. Reações a Exserohilum turcicum (Pass.) Leonard \& Suggs em milho (Zea mays L.) e variabilidade do patógeno. Piracicaba, 1989. 55p. Dissertação (Mestrado) - Escola Superior de agricultura "Luiz de Queiróz", Universidade de São Paulo.

FALLAH MOGHADDAM, P.; PATAKY, J.K. Reactions for isolates from matings of races 1 and 23N of Exserohilum turcicum. Plant Disease, v.78, p.767-771, 1994.

FERREIRA, M.E.; GRATTAPAGLIA, D. Introdução ao uso de marcadores RAPD e RFLP em análise genética. Brasília: EMBRAPA-CENARGEN, 1995. p.74-118. Classes de marcadores moleculares para análise genética; aplicação de marcadores moleculares na genética e melhoramento de plantas. (EMBRAPA. CENARGEN Documento 20).

FREDERIKSEN, R.A. Compedium of sorghum diseases. St. Paul: American Phytopathology Society, 1991. 82 p. 
FREYMARK, P. J.; LEE, M.; WOODMAN, W.L.; MARTISON, C.A . Quantitative and qualitative trait loci affecting host-plant response to Exserohilum turcicum in maize (Zea mays). Theoretical and Applied Genetics, v.87, 537-544, 1993.

GARDINER, J.; MELIA-HANCOCK, S.; HOISINGTON, D.A.; CHAO, S.; COE, E.H. Development of a core RFLP map in maize using an immortalized- $F_{2}$ population. Genetics, v.134, p.917-930, 1993.

GEVERS, H.O. A new major gene for resistance to Helminthosporium turcicum leaf blight of maize. Plant Disease Reporter, v.59, n.4, p.296-300, 1975.

GIANASI, L. Agressividade e raças fisiológicas de Exserohilum turcicum coletados em regiōes produtoras de milho no Brasil, safra 93/94. Lavras, 1996. 40p. Dissertação (Mestrado) - Universidade Federal de Lavras.

GIOVANNONI, J.J.; WING, R.A.; GANAL, M.W.; TANKSLEY, S.D. Isolation of molecular markers from specific chromosomal intervals using DNA pools from existing mapping populations. Nucleic Acids Research, v.19, n.23, p.6553-6558, 1991.

GUPTA, P.K.; BALYAN, H.S.; SHARMA, P.C.; RAMESH, B. Microsatellites in plants: A new class of molecular markers. Current Science, v.70, n.1, p.45$54,1996$.

GUPTA, M.; PARK, F.D.; HOOD, B.; FROME, M.; ZAITLIN, D.; CHYI, J.; BANKS, W.D.; FILNER, P. Identification of RFLP markers for the $\mathrm{Htl}$ gene by comparison of inbreds and their $\mathrm{Htl}$ - conversions. Maize Genetics Cooperation Newsletter, v.63, p.112, 1989. /Resumo/ 
HALDANE, J.B.S. The combination of linkage values and the calculation of distances between the loci of linked factors. Journal of Genetics, v.8, p.299$309,1919$.

HALEY, S.D.; MIKLAS, P.N.; STAVELY, J.; BYRUM, J.; KELLY, J.D. Identification of RAPD markers linked to a major rust resistance gene block in common bean. Theoretical and Applied Genetics, v.86, n.4, p.505-512, 1993.

HALEY, S.D.; AFANADOR, L.; KELLY, J.D. Identification and application of random amplified polymorphic DNA marker for the I gene (potyvirus resistance) in common bean. Phytopathology, v.84, n.2, p.157-160, 1994.

HANSON, W.D. Early generation analysis of lengths of heterozygous chromosome segments around a locus held heterozygous with backcrossing or selfing. Genetics, v.44, p.833-837, 1959.

HEIDRICH-SOBRINHO, E.; HERMES, M.L.T. Studies of genetic resistance and virulence of Trichometasphaeria turcica Lutt. in corn. Revista Brasileira de Genética, v.4, p.17-28, 1981.

HELENTJARIS, T. Implications for conserved genomic struture among plant species. Proceedings National Academy of Sciences USA, v.90, p.83088309, 1993.

HELENTJARIS, T. Atlas of duplicated sequences in maize. Maize Genetics Cooperation Newsletter, v.69, p.67-81, 1995. 
HILLEL, J.; SCHAAP, T.; HABERFELD, A.; JEFFREYS, A.J.; PLOTZKY, Y.; CAHANER, A.; LAVI, U. DNA fingerprints applied to gene introgression in breeding programs. Genetics, v.124, p.783-789, 1990.

HILU, H.M.; HOOKER, A.L. Host-pathogen relationship of Helminthosporium turcicum in resistant and susceptible corn seedlings. Phytopathology, v.54, p.570-575, 1964.

HILU, H.M.; HOOKER, A.L. localized infection by Helminthosporium turcicum on corn leaves. Phytopathology, v.55, p.189-192, 1965.

HOISINGTON, D.; KHAIRALLAH, M.; GONZÄLEZ DE LEÓN, D. Laboratry Protocols : CIMMYT applied molecular genetics laboratory. 2.ed. Mexico: CIMMYT, 1994. 51p.

HOLM, T.; MATZ, E.; BURR, B.; OLIPHANT, A.; PETERSON, C.; EVANS, J.; WRIGHT, S.; SMITH, S. Maize Genetics Cooperation Newsletter, 1994 /Abstract/

HOOKER, A.L. A new type of resistance in corn to Helminthosporium turcicum in seedling corn. Plant Dissease Reporter, v.45, p.780-781, 1961.

HOOKER, A.L. Inheritance of chlorotic-lesion resistance to Helminthosporium turcicum in seedling corn. Phytopathology, v.53, p.660-662, 1963a.

HOOKER, A.L. Monogenic resistance of Zea mays L. to Helminthosporium turcicum. Crop Science, v.3, p.381-383, 1963 b. 
HOOKER, A.L. Helminthosporium turcicum as a pathogen of corn. Reporter Tottori Mycology Institute, v.12, p.115-125, 1975.

HOOKER, A.L. A second major gene locus in corn for chlorotic-lesion resistance to Helminthosporium turcicum. Crop Science, v.17, p.132-135, 1977.

HOOKER, A.L. Additional sources of monogenic resistance in corn to Helminthosporium turcicum. Crop Science, v.17, p.132-135, 1978.

HOOKER, A.L. Relationship of dominant genes in corn for chlorotic lesion resistance to Helminthosporium turcicum. Plant Disease, v.64, p.387-388, 1980.

HOOKER, A.L. Resistance to Helminthosporium turcicum from Tripsacum floridanum incorporated into corn. Maize Genetics Cooperation Newsletter, v.55. p.87-88, 1981.

HOOKER, A.L.; KIM, S.K. Monogenic and multigenic resistance to Helminthosporium turcicum in corn. Plant Disease Reporter, v.57, p.586$589,1973$.

HOOKER, A.L.; NELSON, R.R.; HILU, H.M. Avirulence of Helminthosporium turcicum on monogenic resistant corn. Phytopathology, v.55, p.462-463, 1965.

HUGHES, G.R.; HOOKER, A.L. Gene action conditioning resistance to Northern leaf blight in maize. Crop Science, v.11, p.180-183, 1971. 
JENKINS, M.T.; ROBERT, A.L. Inheritance of resistance to the leaf blight of corn caused by Helminthosporium turcicum. Agronomy Journal, v.44, p.136-140, 1952.

JENKINS, M.; ROBERT, A.L. Evaluating the breeding potential of inbred lines of corn resistant to the leaf blight caused by Helminthosporium turcicum. Agronomy Journal, v.51, p.93-96, 1959.

JIANSHENG, L.; JILLIN, L. Studies on the interaction of monogenic and polygenic resistance to Helminthosporium turcicum in maize (Zea mays L.). Acta Agronomica Sinica, v.10, p. 154-162, 1984.

JORDAN, E.G.; PERKINS, J.M.; SCHALL, R.A.; PEDERSEN, W.L. Occurrence of race 2 of $E$. turcicum on corn in the central and eastern United States. Plant Disease, v.67, p1163-1165, 1983.

KLEIN-LANKHORST, R.M. ; VERMUNT, A.; WEIDE, R.; LIHARSKA, T.; ZABEL, $P$. Isolation of molecular markers from tomato ( $L$. esculentum) using random amplified polymorphic DNA(RAPD). Theoretical and Applied Genetics, v.83, p.108-114, 1991.

KRESOVICH, S.; SZEWE-MCFADDEN, A.K.; BLIEK, S.M.; MCFERSON, J.R. Abundance and characterization of simple-sequence repeats (SSRs) isolated from a size-fractioned genomic library of Brassica napus L. (rapessed). Theoretical and Applied Genetics, v.91, p.206-211, 1995.

LAGERCRANTZ, U.; ELLEGREN, H.; ANDERSSON, L. The abundance of various polymorphic microsatellite motifs differs between plants and vertebrates. Nucleic Acids Research, v.21, p.1111-1115, 1993. 
LEATH, S.; PEDERSEN, W.L. Evaluation of the residual effects of the $\mathrm{Ht}_{1}$ gene with respect to Exserohilum turcicum race 2 in maize inbreds. Phytopathology, v.74, p.818, 1984. /Abstract/

LEATH, S.; PEDERSEN, W.L. Differences in resistance between maize hybrids with or without the $\mathrm{Ht}_{1}$ gene when infected with Exserohilum turcicum race 2. Phytopathology, v.76, p.257-260, 1986.

LEATH, S.; THAKUR, R.P.; LEONARD, K.J. Effects of temperature and light on reaction of corn to race 3 of $E$. turcicum. Phytopathology, v.77, p.1737, 1987. /Abstract/

LEATH, S.; THAKUR, R.P.; LEONARD, K.J. Variation in expression of monogenic resistance in corn to Exserohilum turcicum race 3 under different temperature and light regimes. Phytopathology, v.80, p.309-313, 1990.

LEONARD, K. J.; LEVY, Y.; SMITH, D. R. Proposed nomeclature for pathogenic races of Exserohilum turcicum on corn. Plant Disease, v.73, p.776-777, 1989.

LEVINSON, G.; GUTMAN, G.A. Slipped-strand mispairing: A major mechanism for DNA sequence evolution. Molecular Biology Evolution, v.4, p.203-221, 1987.

LEVY, Y. Variation in fitness among field isolates of Exserohilum turcicum in Israel. Plant Disease, v.75, p.163-166, 1991. 
LEVY, Y.; COHEN, Y. Biotic and environmental factors affecting infection of sweet corn with Exserohilum turcicum. Phytopathology, v.73, p.722-725, 1983.

LIM, S.M.; KINSEY, J.G.; HOOKER, A.L. Inheritance of virulence in Helminthosporium turcicum to monogenic resistant corn. Phytopathology, v. 64, p.1150-11 $51,1974$.

LITT, M.; LUTY, J.A. A hypervariable microsatellite revealed by in vitro amplification of a dinucleotide repeat within the cardiac muscle actin gene. American Journal of Human Genetic, v.44, p.397-401, 1989.

LIPPS, P.E. Interaction of $\mathrm{Ht}$ and partial resistance to Exserohilum turcicum in maize. Plant Disease, v.81, p.277-282, 1997.

LIPPS, P.E.; HITE, R.E. Exserohilum turcicum virulence on corn with the $\mathrm{Ht}$ resistance gene in Ohio. Plant Disease, v.66, p.397-398, 1982.

LOPES, U.V. Herança da resistência de milho a helminthosporiose (Exserohilum turcicum) nas fases de plântula e planta adulta. Viçosa, 1987. 130 p. Dissertação (Mestrado) - Universidade Federal de Viçosa.

MA, Y. "Near-isogenic line" revisited by DNA markers in maize. Botanical Bulletin of Academia Sinica, v.32, p.179-186, 1991.

MCMULLEN, M.D.; POLACCO, M.; GRANT, D.; MUSKET, T; BAYSDORFER, C.; STAEBELL, M.; KOSTER, L.; HOUCHINS, K.; MELIA-HANCOCK, S.; COE, E.H. UMC 1998 Molecular marker map of maize: ETSs, sequence core markers, and nonmaize probes. Maize Genetics Cooperation Newsletter, v.72, p.118-128, 1998. 
MCMULLEN, M.D.; SIMCOX,K.D. Genomic organization of disease and insect resistance genes in maize. Molecular Plant-Microbe Interactions, v.8, n.6, p.811-815, 1995

MAHÉ, A.; BANNEROT, H.; GRISVARD, J. Construction of near-isogenic lines to investigate the efficiency of different resistance genes to anthracnose. Theoretical and Applied Genetics, v.90, p.859-864, 1995.

MARTIN, G.B.; WILLIAMS, J.G.K.; TANKSLEY, S.D. Rapid identification of markers linked to a Pseudomonas resistance gene in tomato by using random primers and near-isogenic lines. Proceedings National Academy of Sciences USA, v.88, p.2336-2340, 1991.

MAUGHAN, P.J.; SAGHAI-MAROOF, M.A.; BUSS, G.R.; HUESTIS, G.M. Amplified fragment length polymorphism (AFLP) in soybean: species diversity, inheritance, and near-isogenic line analysis. Theoretical and Applied Genetics, v.93, p.392-401, 1996.

MELCHINGER, A.E. Use of molecular markers in breeding for oligogenic disease resistance. Plant Breeding, v.104, p.1-19, 1990.

MICHELMORE, R.W.; PARAN, I.; KESSELI, R.V. Identification of markers linked to disease-resistance genes by bulked segregant analysis: $A$ rapid method to detect markers in specific genomic regions by using segregating populations. Proceedings National Academy of Sciences USA, v.88, p.9828-9832, 1991. 
MIKLAS, P.N.; STAVELY, J.; KELLY, J.G. Identification and potential use of a molecular marker for rust resistance in common bean. Theoretical and Applied Genetics, v.85, p.745-749, 1993.

MIYAMOTO, M.; ANDO, I.; RYBKA, K.; KODAMA, O.; KAWASAKI, S. High resolution mapping of the Indica-derived rice blast resistance genes.I.Pi-b. Molecular Plant-Microbe Interactions, v.9, n.1, p.6-13, 1996.

MOORE, S.S.; SARGEANT, L.L.; KING, T.G.; MATICK, J.S.; GEORGES, M.; HERTZEL, D.J.S. Conservation of dinucleotide microsatellites among mammalian genomes allows use of heterologous PCR primer pairs in closely related species. Genomics, v.10, p.654-660, 1991.

MÖRCHEN, M.; CUGUEN, J., MICHAELIS,G., HÄNNI, C., SAUMITOULAPRADE, P. Abundance and length polymorphism of microsatellite repeats in Beta vulgaris L. Theoretical and Applied Genetics, v.92, p.326$333,1996$.

MORGANTE, M.; OLIVIERI, A.M. PCR-amplified microsatellites as markers in plant genetics. The Plant Journal, v.3, p.175-182, 1983.

MUEHLBAUER, G.L.; SPECHT, J.E.; THOMAS-COMPTON, M.A.; STASWICK, P.E.; BERNARD, R.L. Near-isogenic lines - a potential resource in the integration of conventional and molecular marker linkage maps. Crop Science, v.28, p.729-735, 1988.

MULLIS, K.; FALOONA,F.; SCHARF,S.; SAIKI, R.; HORN, G.; ERILICH, H. Specific enzymatic amplification of DNA in vitro: The polymerase chain 
reaction. Cold Spring Harbor Symposium Quantitative Biology, v.51, p.263-273, 1986.

NELSON, R.R. Genetics of horizontal resistance to plant diseases.Annual Review of Phytopathology, v.6, p.359-378, 1978.

NELSON, R.R. The evolution of parasitic fitness. In: HORSFALL, J.G.; COWLING, E.B. (Ed.). Plant disease: An Advanced Treatise. New York: Academic Press. 1979. p.23-46.

NEWTON, C.A; GRAHAM,G.A. PCR. 2 ed. New York: Springer-Verlag, 1997. $192 p$.

O'DONOUGHUE, L.S.; CHONG, J.; WIGHT, C.P.; FEDAK, G.; MOLNAR, S.J. Localization of stem rust resistance genes and association with molecular markers in cultivated oat. Phytopathology, v.86, p.719-727, 1996.

PARAN, I.; KESSELI, R.; MICHELMORE, R. Identification of restriction fragment length polymorphism and random amplified polymorphic DNA markers linked to downy mildew resistance genes in lettuce, using nearisogenic lines. Genome, v.34, p.1021-1027, 1991.

PATAKY, J.K. Effects of race 0 and 1 of Exserohilum turcicum on sweet corn hybrids differing for $\mathrm{Ht}$ and partial resistance to northern leaf blight. Plant Disease, v.78, p. 1189-1193, 1994.

PATAKY, J.K.; PERKINS, J.M.; LEATH, S. Effects of qualitative and quantitative resistance on the development and spread of northern leaf blight of maize 
caused by Exserohilum turcicum races 1 and 2. Phytopathology, v.76, p.1349-1352, 1986.

PATTERSON, E.B.; HOOKER, A.L.; HAGAN, W.L. Location of a dominant gene in maize for resistance a Helminthosporium turcicum. Maize Genetics Cooperation Newsletter, v.37, p.45, 1963.

PATTERSON, E.B.; HOOKER, A.L.; YATES, D.E. Location of $\mathrm{Ht}$ in the long arm of chromosome 2. Maize Genetics Cooperation Newsletter, v.39, p.86-87, 1965.

PEDERSON, W.L. \& LEATH, S. Pyramiding major genes for resistance to maintain residual effects. Annual Review Phytopathology, v.26, p.369-378, 1988.

PENNER, G.A.; CHONG, J.; ÉVESQUE-LEMAY, M.; MOLNAR, S.J.; FEDAK, G. Identification of a RAPD marker linked to the oat stem rust gene $\mathrm{Pg} 3$. Theoretical and Applied Genetics, v.85, p.702-705, 1993.

PERKINS, J.M.; PEDERSEN,W.L. Disease development and yield losses associated with northern leaf blight on corn. Plant Disease, v.71, p.940-943, 1987.

PIECZARKA, D.J. A new race of Helminthosporium turcicum and reaction of sweet corn hybrids to the pathogen. Proceedings Florida State Horticultural Society, v.93, p.281-283, 1980.

PROCUNIER, J.D.; TOWNLEY-SMITH, T.F.; FOX, S.; PRASHAR, S.; GRAY, M.; KIM,W.K.; CZARNECKI, E.; DYCK, P.L. PCR-based RAPD/DGGE 
markers linked to leaf rust resistance genes $L r 29$ and $L r 25$ in wheat (Triticum aestivum L.). Journal Genetics \& Breeding, v.49, p.87-92, 1995.

RAYMUNDO, A.D.; HOOKER, A.L. Measuring the relationship between northern corn leaf blight and yield losses. Plant Disease, v.65, p.325-327, 1981.

RAYMUNDO, A.D.; HOOKER, A.L. Single and combined effects of monogenic and polygenic resistance on certain components of northern corn leaf blight development. Phytopathology, v.72, p.99-103, 1982.

RAYMUNDO, A.D.; HOOKER, A.L.; PERKINS, J.M. Effect of gene HtN on development of NCLB epidemic. Plant Disease Reporter, v.65, p.327-330, 1981.

REITER, R.S.; WILLIAMS, J.G.K.; FELDMANN, K.A.; RAFALSKI, J.A.; TINGEY, S.V.; SCOLNIK, P.A. Global and local genome mapping in Arabidopsis thaliana by using recombinant imbred lines and random amplified polimorphic DNAs. Proceedings National Academy of Sciences USA, v.89, p.1447-1481, 1992.

ROBBINS, W.A.; WARREN, H.L. Inheritance resistance to Exserohilum turcicum in PI 209135, "Mayorbela" variety of mayze. Maydica, v.38, p.209213, 1993.

RONGWEN, J.; CREGAN, P.B; AKKAYA, M.S.; BHAGWAT, A.A.; LAVI, U. The use of simple sequence repeat DNA markers for soybean genotype identification. Theoretical and Applied Genetics, v.90, p.43-48, 1995. 
SAGHAI-MAROOF, M.; BIYASHEV, R.M.; YANG, G.P.; ZHANG, Q.; ALLARD,R.W. Extraordinarily polymorphic microsatellite DNA in barley: species diversity, chromosomal locations, and population dynamics. Proceedings National Academy of Sciences USA, v.91, p.5466-5470, 1994.

SARFATTI, M.; KATAN, J.; FLUHR, R.; ZAMIR, D. An RFLP marker in tomato linked to the Fusarium oxysporum resistance gene 12. Theoretical and Applied Genetics, v.78, p.755-759, 1989.

SCHACHERMAYR, G.M.; MESSMER, M.M.; FEUILLET, C.; WINZELER, H.; WINZELER, M.; KELLER, B. Identification of markers linked to the Agropyron elongatum-derivated leaf rust resistance gene Lr24 in wheat. Theoretical and Applied Genetics, v.90, p.982-990, 1995.

SENIOR, M.L.; CHIN, E.C.L.; LEE, M.; SMITH, J.S.C.; STUBER, C.W. Simple sequence repeat markers developed from maize sequences found in the GENBANK Database: map construction. Crop Science, v.36, p.1676-1683, 1996.

SENIOR, M.L.; HEUN, M. Mapping maize microsatellites and polymerase chain reaction confirmation of the targeted repeats using a CT primer. Genome, v.36, p. 884-889, 1993.

SIGULAS, K.M.; HILL, R.R.; AYERS, J.E. Genetic analysis of Exserohilum turcicum lesion expansion on corn. Phytopathology, v.78, p.149-153, 1988. 
SIMCOX, K.D.; BENNETZEN, J.L. The use of molecular markers to study Setosphaeria turcica resistance in maize. Phytopathology, v.83, p.13261330, 1993.

SMITH, D.R.; KINSEY, J.G. Futher physiological specialization in Helminthosporium turcicum. Plant Disease, v. 64, p.779-781, 1980.

SMITH, D.R.; KINSEY, J.G. Latent period - a possible selection tool for Exserohilum turcicum resistance in corn (Zea mays L.). Maydica, v.38, p.205-208, 1993.

STAM, P.; ZEVEN, C. The theoretical proportion of the donor genome in nearisogenic lines of self fertilizers bred by backcrossing. Euphytica, v.30, p.227$238,1981$.

STAVELY, J.R.; STEADMAN, J.R.; McMILLAN, R.T. New Pathogenic variability in Uromyces appendiculatus in North America. Plant Disease, v.73, p.428-432, 1989.

STRAND, M.; PROLLA, T.A., LISKAY, R.M.; PETES, T.D. Destabilization of tracts of simple repetitive DNA in yeast by mutations affecting DNA mismatch repair. Nature, v. 365, p.274-276, 1993.

TANKSLEY, S.D.; RICK, C.M. Isozymic gene linkage map of the tomato: applications in genetics and breeding. Theoretical and Applied Genetics, v.57, p.161-170, 1980. 
TANKSLEY, S.D; YOUNG, N.D.; PATERSON, A.H.; BONIERBLE, M.W. RFLP mapping in plant breeding: new tools for an old science. BioTechnology, v.7, p.257-264, 1989.

TAUTZ, D. Hypervariability of simple sequences as a general source of polymorphic DNA markers. Nucleic Acids Research, v.17, p.6463-6471, 1989.

THAKUR, R.P.; LEONARD, K.J.; JONES, R.K. Characterization of a new race of Exserohilum turcicum virulent on corn with resistance gene HtN. Plant Disease, v.73, p.151-155, 1989a

THAKUR, R.P.; LEONARD, K.J.; LEATH, S. Effects of temperature and light on virulence of Exserohilum turcicum on corn. Phytopathology, v.79, p.631$635,1989 b$

TINGEY, S.Y.; TUFO, J.P. del. Genetic analysis with random amplified polymorphic DNA markers. Plant Physiology, v.101, p.349-352, 1993.

TUITE, J. Plant pathological methods: fungi and bacteria. Minneapolis: Burgess Publishing Company, 1969. 239p.

WANG, G. L.; PATERSON, A.H. Assessment of DNA pooling strategies for mapping of QTLs. Theoretical and Applied Genetics, v. 88, p.355-361, 1994.

WANG, Z.Y.; TANKSLEY, S.T. Restriction fragment length polymorphism in Oryza sativa L. Genome, v.32, p.1113-1118, 1989. 
WANG, Z.; WEBER, J.L.; ZHONG, G.; TANKSLEY, S.D. Survey of plant short tandem DNA repeats. Theoretical and Applied Genetics, v.88, p.1-6, 1994.

WARREN, H.L. Registration of $\mathrm{H} 102$ and $\mathrm{H} 103$ maize germplasm. Crop Science, v.21, p.477, 1981.

WARREN, H.L. Registration of $\mathrm{H} 110$ and $\mathrm{H} 111$ maize germplasm. Crop Science, v.22, p.1270-1271, 1982.

WEBER, D.; HELENTJARIS, T. Mapping RFLP loci in maize using B-A translocations. Genetics, v.121, p.583-590, 1989.

WEBER, J.L.; MAY, P.E. Abundant class of human DNA polymorphisms which can be typed using the polymerase chain reaction. American Journal of Human Genetic, v.44, p.388-396, 1989.

WELZ, H.G.; GEIGER, G.G. Virulence variation in Setosphaeria turcica populations collected from maize in China, Mexico, Uganda, and Zambia. Phytopathology, v.83, p.1356, 1993. /Abstract/

WINDES, J.M.; PEDERSEN, W.L. An isolate of Exserohilum turcicum virulent on maize inbreds with resistance gene $H t N$. Plant Disease, v.75, p.430, 1991.

WU, K.S.; TANKSLEY, S.D. Abundance, polymorphism and genetic mapping of microsatellites in rice. Molecular General Genetics, v.241, p.225-235, 1993. 
YOUNG, N.D.; TANKSLEY, S.D. Restriction fragment length polymorphism maps and the concept of graphical genotypes. Theoretical and Applied Genetics, v.77, p.95-101, 1988.

YOUNG, N.D.; TANKSLEY, S.D. RFLP analysis of the size of chromosomal segments retained around the $\mathrm{Tm}-2$ locus of tomato during backcross breeding. Theoretical and Applied Genetics, v.77, p.353-359, 1989.

YOUNG, N.D.; ZAMIR, D.; GANAL, M.W.; TANKSLEY, S.D. Use of Isogenic Lines and Simultaneous Probing to Identify DNA Markers Tightly Linked to the Tm-2a Gene in Tomato. Genetics, v.120, p.579-585, 1988.

YU, Z.H.; MACKILL, D.J.; BONMAN, J.M.; TANKSLEY, S.D. Tagging genes for blast resistance in rice via linkage to RFLP markers. Theoretical and Applied Genetics, v.81, p.471-476, 1991.

ZAITLIN, D.; DEMARS, S.J.; GUPTA, M. Linkage of a second gene for NCLB resistance to molecular markers in maize. Maize Genetics Cooperation Newsletter, v.66, p.69-70, 1992.

ZHANG, Q.; SHEN, B.Z.; DAI, X.K.; MEI, M.H.; SAGHAI MAROOF, M.A.; LI, Z.B. Using bulked extremes and recessive class to map genes for photoperiod-sensitive genic male sterility in rice. Proceedings National Academy of Sciences USA, v.91, p.8675-8679, 1994. 